\title{
35. LATE NEOGENE SEDIMENTATION PATTERNS IN THE EASTERN EQUATORIAL PACIFIC OCEAN ${ }^{1}$
}

\author{
John W. Farrell, ${ }^{2}$ Isabella Raffi, ${ }^{3}$ Thomas R. Janecek, ${ }^{4}$ David W. Murray, ${ }^{5}$ Mikhail Levitan, ${ }^{6}$ Kathy A. Dadey, \\ Kay-Christian Emeis, ${ }^{8}$ Mitchell Lyle, ${ }^{9}$ Jose-Abel Flores, ${ }^{10}$ and Steven Hovan ${ }^{11}$
}

\begin{abstract}
The post-middle Miocene evolution of sedimentary patterns in the eastern equatorial Pacific Ocean has been deduced from a compilation and synthesis of $\mathrm{CaCO}_{3}$, opal, and nannofossil assemblage data from 11 sites drilled during Leg 138. Improvements in stratigraphic correlation and time scale development enabled the construction of lithostratigraphic and chronostratigraphic frameworks of exceptional quality. These frameworks, and the high sedimentation rates (often exceeding $4 \mathrm{~cm} / \mathrm{k} . \mathrm{y}$.) provided a detailed and synoptic paleoceanographic view of a large and highly productive region. The three highlights that emerge are: (1) a middle late Miocene "carbonate crash" (Lyle et al., this volume); (2) a late Miocene-early Pliocene "biogenic bloom"; and (3) an early Pliocene "opal shift". During the carbonate crash, an interval of dissolution extending from $\sim 11.2$ to $7.5 \mathrm{Ma}, \mathrm{CaCO}_{3}$ accumulation rates declined to near zero over much of the eastern equatorial Pacific, whereas opal accumulation rates remained substantially unchanged. The crash nadir, near $9.5 \mathrm{Ma}$, was marked by a brief shoaling of the regional carbonate compensation depth by more than $1400 \mathrm{~m}$. The carbonate crash has been correlated over the entire tropical Pacific Ocean, and has been attributed to tectonically-induced changes in abyssal flow through the Panamanian seaway. The biogenic bloom extended from 6.7 to 4.5 $\mathrm{Ma}$, and was characterized by an overall increase in biogenic accumulation and by a steepening of the latitudinal accumulation gradient toward the equator. The bloom has been observed over a large portion of the global ocean and has been linked to increased productivity. The final highlight, is a distinct and permanent shift in the locus of maximum opal mass accumulation rate at $4.4 \mathrm{Ma}$. This shift was temporally, and perhaps causally, linked to the final closure of the Panamanian seaway. Before $4.4 \mathrm{Ma}$, opal accumulation was greatest in the eastern equatorial Pacific Basin (near $0^{\circ} \mathrm{N}, 107^{\circ} \mathrm{W}$ ). Since then, the highest opal fluxes in the equatorial Pacific have occurred in the Galãpagos region (near $3^{\circ} \mathrm{S}, 92^{\circ} \mathrm{W}$ ).
\end{abstract}

\section{INTRODUCTION}

The paleoceanography of the eastern equatorial Pacific Ocean (EEP) deserves careful attention for two main reasons. First, because up to $50 \%$ of global new production occurs in the EEP (Chavez and Barber, 1987), a large part of the ocean's productivity signal can be reconstructed from a relatively small region. This provides important information about the cycling of carbon, silica, and other nutrients. Second, it has long been recognized (e.g., Arrhenius, 1952) that past changes in climate and oceanography are recorded in detail in the EEP sediments, primarily because of high sedimentation rates of biogenic material. As a result, the primary focus of Deep Sea Drilling Program (DSDP) and Ocean Drilling Program (ODP) Legs 5, 8, 9, 16, 68, 69, 85 , and 138 was to determine the processes that produced the sedimentary record and the role the EEP played in climate and oceano-

' Pisias, N.G., Mayer, L.A., Janecek, T.R., Palmer-Julson, A., and van Andel, T.H (Eds.), 1995. Proc. ODP, Sci. Results, 138: College Station, TX (Ocean Drilling Program).

${ }^{2}$ Department of Geological Sciences, Brown University, Providence, RI 02912-1846, U.S.A. (Now at Department of Oceanography, University of British Columbia, Vancouver, B.C. V6T 1Z4, Canada.)

${ }^{3}$ Università degli Studi "G. D'Annunzio," - Facoltà di Scienze Matematiche, Fisiche e Naturali, Castelgandolfo. Italy 00040.

${ }_{4}^{4}$ Ocean Mapping Group, University of New Brunswick, Fredericton, New Brunswick E3B 5A3, Canada.

${ }^{5}$ Department of Geological Sciences, Brown University, Providence, RI 02912-1846, U.S.A. Russia.

${ }^{6}$ P.P. Shirshow Institute of Oceanology, Russian Academy of Sciences, Moscow,

${ }^{7}$ Hawaii Institute of Geophysics, School of Ocean and Earth Science and Technology, University of Hawaii, 2525 Correa Road, Honolulu, HI 96822, U.S.A.

${ }^{8}$ Geologisch-Palăontologisches Institut, Universităt Kiel, Olshausenstrasse 40-60, D-2300 Kiel, Federal Republic of Germany.

${ }^{9}$ Center for the Geophysical Investigation of the Shallow Subsurface, Boise State University, Boise, ID 83725 , U.S.A.

${ }^{10}$ Departamento de Geologia, Universidad de Salamanca, S-37008 Salamanca, Spain.

${ }^{11}$ Antarctic Research Facility, Department of Geology, Florida State University, Tallahassee, FL 32306, U.S.A. graphic change. An excellent summary of earlier work was presented by van Andel et al. (1975). In this study, we examined over 5 kilometers of late Neogene sediments recovered from 11 sites drilled during Leg 138 (Fig. 1). The results update our paleoceanographic understanding of the Guatemala Basin, the Galãpagos region, and the eastern equatorial Pacific Basin.

Several improvements in technology and scientific approach enabled the Leg 138 scientific party to improve upon the reconstruction of the EEP paleoceanographic record. First, routine assembly of composite sedimentary records (Hagelberg et al., 1992) was made possible by improvements in advanced piston coring techniques and by the collection of on board stratigraphies such as gamma-ray attenuation porosity evaluator (GRAPE) and magnetic susceptibility. Careful analysis of these stratigraphies documented missing sediment between successive cores, even where recovery was reported as $100 \%$ or more. The value of these composite records has been recognized for some time now (e.g., Legs 94, 111, 115, 117, and 121, as discussed by Farrell and Janecek, 1991). Second, the continuity of the composite sections and the similarities in sediment wet bulk density among the sites enabled the scientific party to establish fine-scale correlations among nearly all the sites. Third, a new late Neogene time scale was developed, and used to convert the sedimentary records from depth to time in an internally consistent and highly-resolved manner (Shackleton et al., this volume). Calibration of this time scale was based on the correlations between high frequency changes in sediment density (GRAPE) and orbital insolation.

Our examination of the late Neogene history of the EEP was based on the sedimentary sections recovered from the 11 sites drilled during Leg 138. Temporal resolution of the records averages 40 k.y. and ranges from less than 2 k.y. to more than 200 k.y., depending on the sedimentation rates and the sampling density. We also examined the preservation state of the biogenic $\mathrm{CaCO}_{3}$, based on the characterization of nannofossil assemblages. These data helped constrain interpretations of the $\mathrm{CaCO}_{3}$ data in terms of dissolution, productivity, and dilution. 

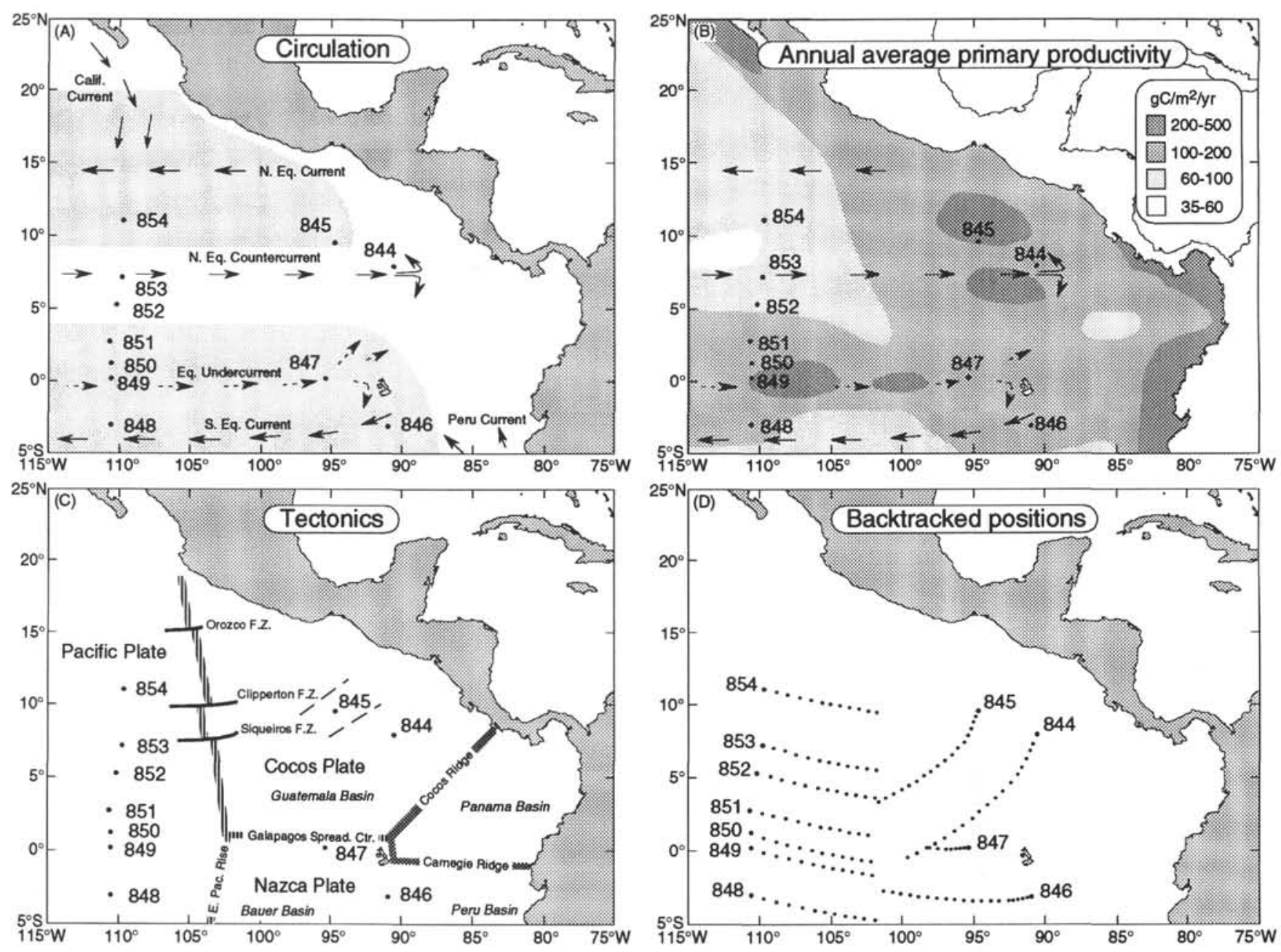

Figure 1. Maps showing (A) ocean circulation, (B) primary productivity (from Berger et al., 1987), (C) tectonic framework, and (D) backtracked positions of the 11 sites drilled during Leg 138. The shaded areas in Figure 1A mark the extent of the South and North Equatorial Currents. All are surface currents except the Equatorial Undercurrent. The sites are located on three tectonic plates in various basins (Fig. IC). The backtracked positions in Figure ID are from Pisias et al. (this volume); dots represent positions at 1-m.y. increments. Sites 844 through 847 have drifted eastward over time, whereas the other sites have moved to the west.

We wish to emphasize that the data summarized here are laboratory measurements of $\% \mathrm{CaCO}_{3}, \%$ opal, and $\mathrm{CaCO}_{3}$ preservation rather than proxies estimated from analytical measurements. Although laboratory data remain the reference point for interpretation, we encourage the reader to examine the paleoceanographic studies in this volume that were based on surrogate indicators of bulk sediment composition, such as $\% \mathrm{CaCO}_{3}$ inferred from GRAPE (Hagelberg et al., this volume) and from down hole geochemical logs (Dadey and Lyle, this volume; Lyle et al., this volume). Calibration of these proxies to real sediment composition is essential but is not simple (Mayer, 1991; Herbert and Mayer, 1991). Nevertheless, because most of the sediment in the EEP is either $\mathrm{CaCO}_{3}$ or opal, the calibration works reasonably well (e.g., Murray et al., this volume) with a maximum error estimate of about $7 \%$ (Hagelberg et al., this volume). Because proxy data are generally available at a much higher resolution than the discretely measured values, proxy sediment histories provide detail that reflects oceanographic and climatic processes acting at high $\left(10^{3}\right.$ to $\left.10^{5} \mathrm{yr}\right)$ frequencies, which are important for understanding processes acting at Milankovitch and sub-Milankovitch frequencies.

We focused our attention on the temporal and spatial changes in sediment composition and accumulation rate. Special attention was placed on three highlights. The first was the collapse of the carbonate system in the EEP during the middle late Miocene (centered at 9.5
Ma), which was characterized by a $70 \%-90 \%$ decrease in $\% \mathrm{CaCO}_{3}$, a decline in the $\mathrm{CaCO}_{3} \mathrm{MAR}$, increased dissolution of nannofossils, and a shoaling of the carbonate compensation depth (CCD). The effects of the collapse were greatest and most enduring in the Guatemala Basin, but a large response was recorded at nearly all Leg 138 sites, and indeed, over much of the equatorial Pacific. The second highlight was the "biogenic bloom" which began in the late Miocene $(6.7 \mathrm{Ma})$ and extended into the early Pliocene (4.5 Ma) (Mayer, Pisias, Janecek, et al., 1992). Biogenic accumulation rates increased several fold over this interval in the EEP, as well as in the low latitude Indo-Pacific (Peterson et al., 1992; Berger et al., 1993) and the North Pacific (Leg 145 Scientific Party, 1993). The third highlight was the distinct reversal in the spatial pattern of opal MAR at 4.4 Ma, that we associated with the final closing of the Panamanian seaway.

\section{DATA}

We examined the bulk-sediment composition, flux, and carbonate preservation of the 11 sites drilled during Leg 138. All shipboard and post-cruise $\% \mathrm{CaCO}_{3}$ and \%opal data thus far available have been synthesized here. Although most of these data were originally reported elsewhere in this volume, or in the Initial Results volume (Table 1), all data have been included in Appendixes A and B (CD- 
Table 1. Site locations and data sources.

\begin{tabular}{|c|c|c|c|c|c|c|c|c|c|}
\hline Site & Latitude & Longitude & $\begin{array}{l}\text { Water } \\
\text { depth } \\
\text { (m) }\end{array}$ & $\begin{array}{c}\text { Sediment } \\
\text { thickness } \\
\text { (m) }\end{array}$ & $\begin{array}{c}\text { Oldest } \\
\text { sediment } \\
(\mathrm{Ma})\end{array}$ & $\begin{array}{c}\mathrm{CaCO}_{3} \\
\text { reference } \\
(\%)\end{array}$ & $\begin{array}{c}\text { Opal } \\
\text { reference } \\
(\%)\end{array}$ & $\begin{array}{c}\text { Terrigenous } \\
\text { reference } \\
(\%)\end{array}$ & $\begin{array}{l}\text { Nannofossil } \\
\text { preservation }\end{array}$ \\
\hline 844 & $7^{\circ} 55.8^{\prime} \mathrm{N}$ & $90^{\circ} 28.8 \mathrm{~W}$ & 3415 & 291 & 17.5 & 1,4 & 4,7 & 8 & 8 \\
\hline 845 & $9^{\circ} 35.0^{\prime} \mathrm{N}$ & $94^{\circ} 35.4 \mathrm{~W}$ & 3704 & 292 & 16.6 & 1,4 & 4,7 & 8 & 8 \\
\hline 846 & $3^{\circ} 05.7^{\prime} \mathrm{S}$ & $90^{\circ} 49.1 \mathrm{~W}$ & 3296 & 422 & 18.1 & $1,2,4,5$ & 4,7 & 8 & 8 \\
\hline 847 & $0^{\circ} 11.6 \mathrm{~N}$ & $95^{\circ} 19.2 \mathrm{~W}$ & 3334 & $247^{\mathrm{a}}$ & 6.7 & $1,3,4$ & $3,4,7$ & 8 & 8 \\
\hline 848 & $2^{\circ} 59.6 \mathrm{~S}$ & $110^{\circ} 28.8 \mathrm{~W}$ & 3855 & 94 & 11.4 & 1,4 & 4.7 & 6,8 & 8 \\
\hline 849 & $0^{\circ} 11.0^{\circ} \mathrm{N}$ & $110^{\circ} 31.2 \mathrm{~W}$ & 3839 & 349 & 11.6 & 1,4 & 4,7 & 6,8 & 8 \\
\hline 850 & $1^{\circ} 17.8 \mathrm{~N}$ & $110^{\circ} 31.3 \mathrm{~W}$ & 3786 & 400 & 12.0 & 1,4 & 4,7 & 8 & 8 \\
\hline 851 & $2^{\circ} 46.2 \mathrm{~N}$ & $110^{\circ} 34.3 \mathrm{~W}$ & 3760 & 321 & 12.6 & 1,4 & 4,7 & 8 & 8 \\
\hline 852 & $5^{\circ} 17.6 \mathrm{~N}$ & $110^{\circ} 04.6 \mathrm{~W}$ & 3860 & 117 & 11.4 & 1,4 & 4.7 & 6,8 & 8 \\
\hline 853 & $7^{\circ} 12.7^{\prime} \mathrm{N}$ & $109^{\circ} 45.1 \mathrm{~W}$ & 3714 & 66 & 8.9 & 1,4 & 4,7 & 6,8 & 8 \\
\hline 854 & $11^{\circ} 13.4 \mathrm{~N}$ & $109^{\circ} 35.7 \mathrm{~W}$ & 3568 & 46 & 9.9 & 1,4 & 4,7 & 8 & 8 \\
\hline
\end{tabular}

Notes: Numbered references are I= Mayer, Pisias, Janecek, et al. (1992): 2 = Dadey and Lyle

(this volume); 3 = Murray et al. (this volume); $4=$ Levitan et al. (this volume); $5=$ Emeis et al. (this volume);

$6=$ Hovan (this volume); $7=$ Janecek (laboratory, Texas A\&M University); $8=$ this chapter.

${ }^{a}$ Basement not reached.

ROM, back pocket) for convenience. We also included associated parameters in the appendixes, such as the estimated age of each sample. Most of the nannofossil assemblage data (Appendix C, CDROM, back pocket) were collected on board the ship by Isabella Raffi and Jose-Abel Flores. We have estimated the terrigenous concentration (Appendix B) of the sediments as the nonbiogenic component, and we have compared these estimates to the measured values reported by Hovan (this volume). Although we focused our attention on the interval extending back to $13 \mathrm{Ma}$, data from Sites 844,845 , and 846 extend to $17.1,16.6$, and $17.7 \mathrm{Ma}$, respectively, and were included in the appendixes for completeness.

\section{METHODS AND INTERLABORATORY COMPARISONS}

\section{Calcium Carbonate}

Several methods were used to determine the calcium carbonate content of the dry bulk sediments. Most investigators used a coulometric, gasometric (e.g., Jones and Kateris, 1983), or LECO-type procedure, and detailed descriptions can be found in the individual reports. Replicate analyses of both samples and standards generally indicated an analytical precision that was better than $1 \%$ by weight in the various laboratories, including that of the Resolution. Although rigorous inter-laboratory comparisons have generally not been attempted, we observed no significant offset in values for $\% \mathrm{CaCO}_{3}$ among the various data sets.

\section{Opal}

We summarized sedimentary opal concentrations from three sources and found that some values may have underestimated the true opal concentration of the sediments by as much as $11 \%$. Levitan et al. (this volume) measured opal content by the $\mathrm{X}$-ray fluorescence spectroscopy method and by double leaching with $5 \%$ hot $\mathrm{Na}_{2} \mathrm{CO}_{3}$ for 2 $\mathrm{hr}$ and a subsequent treatment with $\mathrm{HCl}$. Murray et al. (this volume) and Janecek (this study) used a modified version of the Mortlock and Froelich (1989) wet-alkaline extraction technique.

To determine the consistency of the \%opal values, we examined the values from the top $98 \mathrm{~m}$ composite depth (mcd) $(\sim 0-3 \mathrm{Ma})$ at Site 847 , the only interval analyzed by all three laboratories. We found that Murray et al.'s values $(N=655)$ averaged $22.5 \%$, Janecek's averaged $18.3 \%(N=62)$, and Levitan et al.'s values $(N=10)$ averaged $16.9 \%$. All three records show similar variations in amplitude, despite the apparent $4 \%$ to $6 \%$ offset in absolute values from Murray et al.'s record (Fig. 2). To examine this offset further, aliquots from 16 samples from Holes 847A and 847B were analyzed by both Janecek and Murray. Murray's values averaged $4.4 \%$ higher than did those of Janecek, almost exactly the mean difference observed over the inter- val from Site 847 compared in Figure 2. The range about this mean value of $4.4 \%$ was large; Murray's values ranged from $19 \%$ larger to $3 \%$ smaller than those of Janecek. Some of the larger differences, however, have been attributed to occasional analytical difficulties (Appendix B; T.R. Janecek, pers. comm., 1994). Finally, only a small portion $(<1 \%)$ of the difference between laboratories can be attributed to the use of different values to convert $\mathrm{Si}$ concentrations to \%opal. Janecek used a value of 2.4 , whereas Murray et al. used 2.5, to represent a mixture of diatom and radiolarian skeletons.

To address concerns that the use of the slightly modified Mortlock and Froelich (1989) method underestimated the amount of opal in the sediments, Murray et al. conducted several tests. Radiolarian parts that escaped dissolution were occasionally observed in the residual material from the opal extraction; however Murray et al. demonstrated that these skeletal fragments constituted a minor fraction $(<4 \%)$ of the total weight percent of opal. They concluded that $>95 \%$ of the opal was extracted from the sediment in their laboratory. The difference between Janecek's results and those of Murray et al. are harder to explain. They both used the same general method, but small differences may be attributed to variations in the time over which opal was extracted and the rigor of stirring. Murray et al. (this volume; pers. comm., 1993) performed tests that eliminated the possibility of their opal values being higher than those of Janecek as a result of silica extraction from clays. Based on the results from Murray et al., we think that the opal concentration measurements were low, by as little as $1 \%$ or $2 \%$, to as much as $11 \%$ (based on the $4 \%$ to $6 \%$ gap between values of Janecek and Levitan and those obtained by Murray et al., which themselves may be as much as $5 \%$ too low). Nevertheless, we are confident that the spatial and temporal patterns developed from the \%opal data are generally representative of sediment accumulation.

\section{Terrigenous}

We estimated the terrigenous concentration of the bulk sediment (\%terrigenous) as equaling $100 \%-\%$ opal $-\% \mathrm{CaCO}_{3}$. This provided only a crude, first-order approximation, one that clearly overestimated, as we did not account for organic matter, salt, hydrothermal and volcanic sediments, and other minor constituents. Furthermore, because \%opal values were generally underestimated, as mentioned above, our overestimation of \%terrigenous values was potentially greater.

We compared our estimated \%terrigenous values for Sites 848, 849,852 , and 853 with those measured analytically (Hovan, this volume) (Table 2 and Fig. 3). Unfortunately, we could not compare aliquots from the same sample; we simply compared mean values over the same sedimentary interval. We attributed most of the large difference between estimated and measured terrigenous sediment accumulation (Table 2) to the difference in \%terrigenous values, because the other factors used to calculate accumulation (dry bulk 


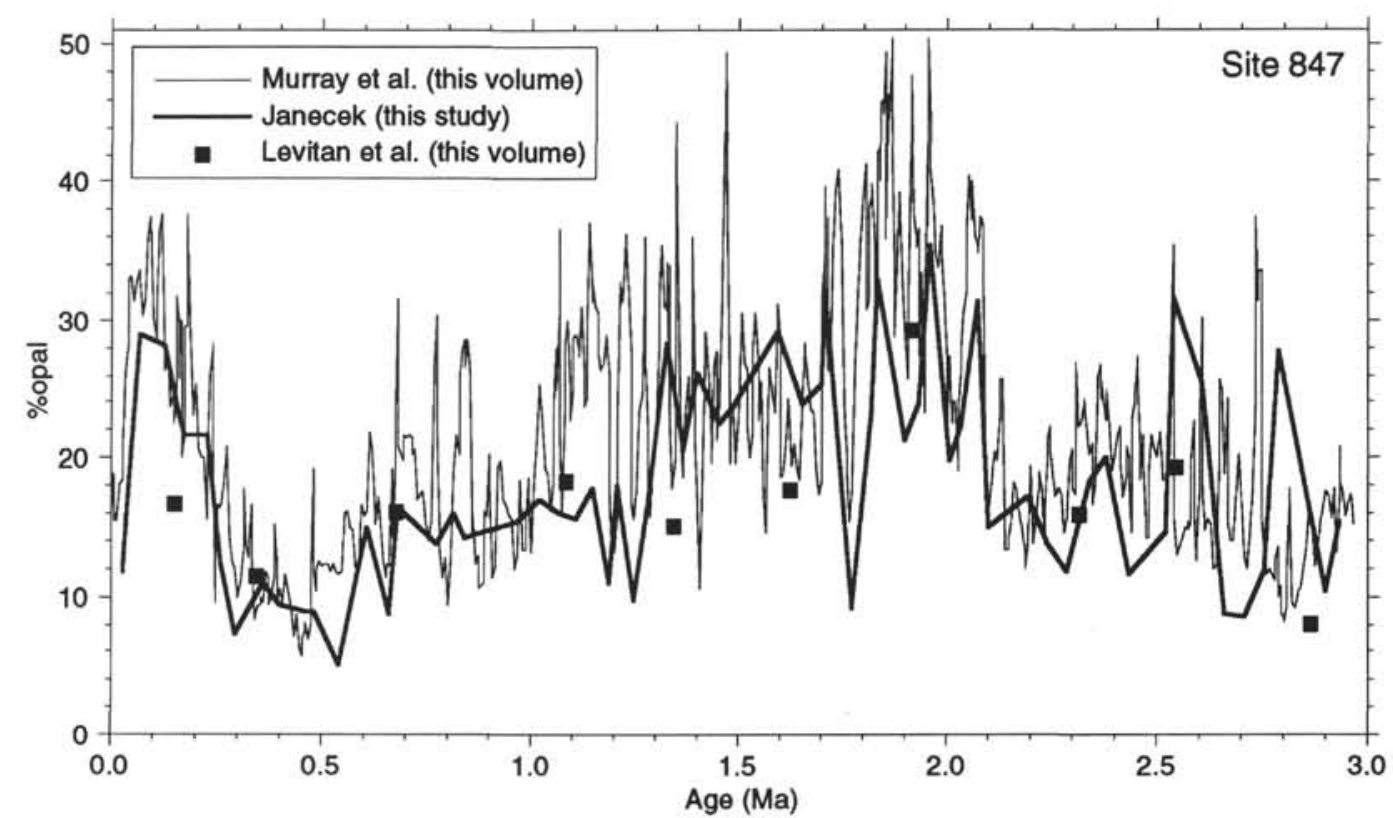

Figure 2. Comparison of Site 847 \%opal data from three laboratories shows the same general pattern, but offsets in absolute values, as discussed in the text.

Table 2. Comparison of measured and estimated \% terrigenous sedimentary parameters.

\begin{tabular}{|c|c|c|c|c|}
\hline Site: & 848 & 849 & 852 & 853 \\
\hline Age interval (Ma): & $0-11.20$ & $0-10.21$ & $0-10.36$ & $0-8.48$ \\
\hline $\begin{array}{l}\text { Number of samples } \\
\text { Hovan (this volume) } \\
\text { This study } \\
\text { Difference (\%) }\end{array}$ & $\begin{array}{l}70 \\
83 \\
19\end{array}$ & $\begin{array}{r}158 \\
223 \\
41\end{array}$ & $\begin{array}{l}73 \\
94 \\
29\end{array}$ & $\begin{array}{r}55 \\
55 \\
0\end{array}$ \\
\hline $\begin{array}{l}\text { Mean inst. sed. rate }(\mathrm{cm} / \mathrm{k} . \mathrm{y} .) \\
\text { Hovan (this volume) } \\
\text { This study } \\
\text { Difference }(\%)^{\mathrm{a}}\end{array}$ & $\begin{array}{l}1.21 \\
1.17 \\
-3\end{array}$ & $\begin{array}{l}4.71 \\
5.28 \\
12\end{array}$ & $\begin{array}{l}1.42 \\
1.37 \\
-4\end{array}$ & $\begin{array}{l}1.06 \\
-1\end{array}$ \\
\hline $\begin{array}{l}\text { Dry bulk density (g/cm } 3 \text { ) } \\
\text { Hovan (this volume; measured) } \\
\text { This study (estimated, see Table } 3 \text { ) } \\
\text { Difference }(\%)^{\mathrm{a}}\end{array}$ & $\begin{array}{l}0.67 \\
0.61 \\
-9\end{array}$ & $\begin{array}{l}0.69 \\
0.74 \\
7\end{array}$ & $\begin{array}{l}0.66 \\
0.63 \\
-5\end{array}$ & $\begin{array}{l}0.62 \\
0.60 \\
-3\end{array}$ \\
\hline $\begin{array}{l}\text { Terrigenous (\%) } \\
\text { Hovan (this volume; measured) } \\
\text { This study }{ }^{\mathrm{b}} \\
\text { Difference }(\%)^{\mathrm{a}}\end{array}$ & $\begin{array}{c}4.62 \\
15.52 \\
236\end{array}$ & $\begin{array}{r}2.48 \\
12.38 \\
399\end{array}$ & $\begin{array}{l}11.41 \\
18.94 \\
66\end{array}$ & $\begin{array}{l}16.60 \\
24.01 \\
45\end{array}$ \\
\hline $\begin{array}{l}\text { Terrigenous MAR } \\
\text { Hovan (this volume) } \\
\text { This study } \\
\text { Difference }(\%)^{\mathrm{a}}\end{array}$ & $\begin{array}{l}0.026 \\
0.096 \\
269\end{array}$ & $\begin{array}{c}0.052 \\
0.419 \\
706\end{array}$ & $\begin{array}{l}0.084 \\
0.143 \\
70\end{array}$ & $\begin{array}{l}0.106 \\
0.139 \\
31\end{array}$ \\
\hline $\begin{array}{l}\text { Mean opal }(\%) \text { (this study) } \\
\text { Mean organic matter }(\%)^{\mathrm{d}}\end{array}$ & $\begin{array}{r}11.83 \\
0.12\end{array}$ & $\begin{array}{r}13.81 \\
0.10\end{array}$ & $\begin{array}{l}5.17 \\
0.13\end{array}$ & $\begin{array}{l}1.82 \\
0.06\end{array}$ \\
\hline
\end{tabular}

"Positive difference indicates this study's value is larger.

${ }^{b}$ Estimated as equaling $100-\% \mathrm{CaCO}_{3}-\%$ opal.

${ }^{\mathrm{c}}$ Mass accumulation rate ( $\mathrm{g} / \mathrm{cm}^{2} \mathrm{k} . \mathrm{y}$.).

${ }^{\mathrm{d}}$ From Mayer, Pisias, Janecek, et al. (1992).

density and sedimentation rate) differed little between Hovan's study (this volume) and ours.

Several factors may have contributed to the difference between the estimated and measured \%terrigenous values. At all four sites, our estimated values covaried with the measured values, but were larger by $7 \%$ to $11 \%$ (Table 2 and Fig. 3). Interestingly, our overestimations were largest at the site closest to the equator (Site 849) and grew progressively smaller away from there. This trend can be attributed to the fact that the equatorial site had the highest \%opal (Table 2), which may have been underestimated by as much as $11 \%$.
Other factors possibly contributing to the difference between estimated and measured \%terrigenous values also were considered. The mean concentrations of organic matter at these four sites are low and vary little (Table 2); thus, they do not add to the difference. Salt that remained in the sediment after the pore waters dried was not accounted for by our \%terrigenous estimation and, therefore, contributed to the discrepancy from the measured values. If more salt had been found in the equatorial sites than in the off-equatorial sites, we could explain a successively greater portion of the observed increase between estimated and measured \%terrigenous values in sites ap- 

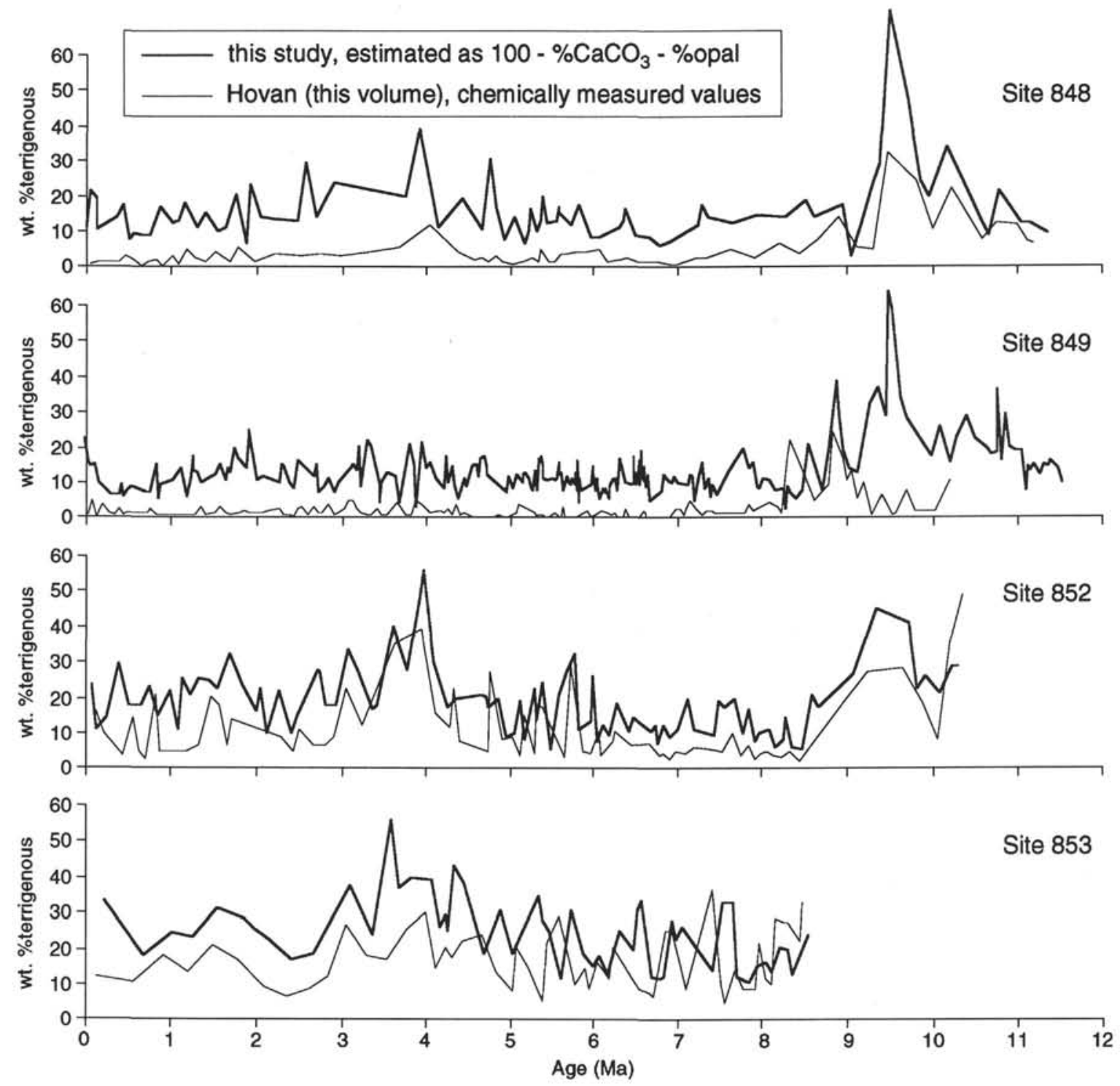

Figure 3. Comparison between measurements and estimates of the sedimentary terrigenous concentrations (Hovan, this volume) shows a generally good covariation, but the estimated values are significantly larger, especially at equatorial Sites 848 and 849 , where opal percentages are high. As discussed in the text, the estimated terrigenous values are too large because they neglect all sedimentary components except $\mathrm{CaCO}_{3}$ and opal, and, more importantly, because \%opal measurements are low (by as much as $11 \%$ ).

proaching the equator. We did not quantify the salt content of the sediments, but we think that the equatorial sites actually have a lower salt content and, thus, a smaller overestimation (a few weight percent) of the \%terrigenous values than those of the off-equatorial sites. This thought is based on the observation that equatorial Site 849 has lower porosity and lower water content (and thus less dissolved salt) than off-equatorial Site 853.

Latitudinal differences in \%opal, rather than salt, are the most likely explanation of the latitudinal trend in the inconsistencies between estimated and measured \%terrigenous values. When approaching the discrepancy from another direction, we noted that Hovan's chemical extraction method required a base that was sufficiently strong to remove all opal, but apparently also dissolved some of the clays. Hovan (this volume) used a correction factor to account for clay dissolution, so we could not completely resolve the discrepancy in this fashion, but it may account for some of the difference. In summary, the estimated \%terrigenous values were greater than the measured values, mostly because the estimation neglected minor sedimentary constituents and used \%opal values that possibly were low.

\section{Nannofossil Assemblage Characterization}

A complete description of the methods used to examine and describe nannofossil assemblages can be found in Rio et al. (1990) and in the "Explanatory Notes" chapter in Mayer, Pisias, Janecek, et al. (1992). Briefly, nannofossil assemblages in smear slides prepared from unprocessed material were routinely examined by the shipboard paleontologists with a light microscope at a magnification of about $1250 \mathrm{x}$ using cross-polarized and transmitted light. In addition to evaluating the assemblages for taxonomic and biostratigraphic information, qualitative evaluations of the abundance of the nannofossils, their preservation state, and the degree of both etching and overgrowth were noted. Abundance was characterized in a semiquantitative fashion as $4=\mathrm{A}$ (abundant) $=$ usually more than 10 specimens occurred per field; $3=$ $\mathrm{C}($ common $)=$ one to 10 specimens per field; $2=\mathrm{F}$ (few) $=$ one specimen per $1-10$ fields; $1=\mathrm{R}$ (rare) $=$ one specimen per more than 10 fields; and $0=\mathrm{B}$ (barren) $=$ no specimens were present.

The "average" preservation state of the nannofossils was characterized as $4=\mathrm{G}$ (good) $=$ specimens showed little or no dissolution 
and/or overgrowth; $3=\mathrm{M}-\mathrm{G}$ (moderate to good) $=$ specimens showed slight to moderate dissolution and/or overgrowth and the identification of some specimens was impaired; $2=\mathrm{M}$ (moderate) $=$ specimens showed moderate dissolution and/or overgrowth, and identification was impaired at the specific level; $1=\mathrm{P}$ (poor) $=$ specimens showed extreme dissolution and/or overgrowth; and $0=\mathrm{B}$ (barren) $=$ no specimens were present.

Because the paleontologists observed considerable variation in the degree of preservation of individual specimens within the "average" nannofossil assemblage, they also evaluated the degree of etching (E) and overgrowth (O), following the criteria of Roth and Thierstein (1972) and Roth (1973). These were characterized as $4=$ barren sample; 3 = severe effects of dissolution and overgrowths; $2=$ moderate dissolution and overgrowth; 1 = slight dissolution and overgrowth; and $0=$ no sign of dissolution and overgrowth.

\section{Age Models}

Sedimentary records were converted from depth series to time series by using the chronostratigraphic control points (age models) of Shackleton et al. (this volume). This chronostratigraphy is a significant departure from Berggren et al.'s (1985) time scale (as much as 800 k.y. at some intervals). Given the unfamiliarity of this time scale, we provide a graphical representation of the difference between the more commonly used time scale of Berggren et al. (1985) and that used here (Fig. 4). Ages referred to in the remainder of this chapter are relative to the new time scale, except where noted.

The age models were based on the revised meters composite depth (rmcd) scale developed by Hagelberg et al. (this volume). Here, we have used the meters composite depth (mcd) scale, instead of the rmcd, because the differences in absolute depth for any given sample between the scales are small, generally on the order of centimeters.

\section{Mass Accumulation Rate}

Mass accumulation rate (MAR) is the mass of a sedimentary material preserved per unit area per unit time, commonly expressed in units of grams, per square centimeter, per $1000 \mathrm{yr}\left(\mathrm{g} / \mathrm{cm}^{2} / \mathrm{k}\right.$.y. $)$. We calculated the MARs of $\mathrm{CaCO}_{3}$, opal, and terrigenous material from the weight percent of each sediment type, the linear sedimentation rate (LSR, in $\mathrm{cm} / \mathrm{k} . \mathrm{y}$ ), and the dry bulk density (DBD, in $\left.\mathrm{g} / \mathrm{cm}^{3}\right)$. For example, the $\mathrm{CaCO}_{3}$ MAR was calculated as

$$
\mathrm{CaCO}_{3} \mathrm{MAR}=\left[\% \mathrm{CaCO}_{3} \times \mathrm{LSR} \times \mathrm{DBD}\right] / 100 .
$$

The LSR for each site was based on the chronostratigraphy provided by Shackleton et al. (this volume). An age was interpolated for each sample depth with no adjustment for the differences between mcd and rmcd. An instantaneous LSR was assigned to each sample as

$$
\text { Sample } \operatorname{LSR}(i)=\frac{(\text { Depth } i+1)-\text { Depth } i}{(\text { Age } i+1)-\text { Age } i},
$$

where $i$ is the sample for which the LSR is calculated, and $i+1$ is the next downhole sample. A more smoothly varying LSR would result if the LSR were calculated as

$$
\text { Sample LSR }(i)=\frac{(\text { Depth } i+1)-(\text { Depth } i-1)}{(\text { Age } i+1)-(\text { Age } i-1)} \text {, }
$$

but the difference was considered insignificant in terms of the results presented here.

We estimated the DBD for each sample based on the associated $\% \mathrm{CaCO}_{3}$ value. For each site, we determined the relationship between shipboard $\% \mathrm{CaCO}_{3}$ and shipboard dry bulk density measured on the same samples (Mayer, Pisias, Janecek, et al., 1992). These relationships are described by third-order polynomial equations in Table 3. The correlation coefficients ( $r$ values) for these equations range from 0.40 to 0.98 and average 0.78 . Additional support for the veracity of these DBD estimates is provided by the comparison in Table 2, which shows that, on average, the Hovan (this volume) DBD measurements are similar to our estimates.

We stress that MAR estimates are only as accurate and detailed as the LSR estimates and the chronostratigraphy upon which they are based. Changes in sediment concentration and DBD data are generally secondary in importance because, in absolute values, the variations in LSR are almost always greater than those in concentration and DBD. A detailed chronostratigraphy from GRAPE tuning (Shackleton et al., this volume) or from a $\delta^{18} \mathrm{O}$ record enables one to determine LSR changes, and thus MAR changes on the order of $10^{4}$ yr. A chronostratigraphy based on linear interpolation between age estimates separated by a long time interval, such as between the core top (Holocene) and the Brunhes/Matuyama geomagnetic reversal, cannot resolve high frequency fluctuations in LSR. As a result, MAR variations that are based on a low-resolution chronostratigraphy are controlled by variations in $\% \mathrm{CaCO}_{3}$ and $\mathrm{DBD}$, which do not necessarily reveal the dynamics of oceanographic change at high frequencies. Similarly, given a temporal resolution of only $10^{4} \mathrm{yr}$, we cannot determine the sedimentation rates of the relatively thin beds of laminated diatom sediments that accumulated in several intervals in the Leg 138 sites (Kemp and Baldauf, 1993).

\section{REGIONAL SETTING}

The modern regional setting of the EEP provides a framework to understand how the interaction of tectonics, oceanography, biology, and climate controls sedimentation. Although the modern setting is not completely analogous to that of the Miocene and Pliocene oceans, numerous similarities exist across time.

\section{Upper Ocean Circulation and Biological Productivity}

Surface-water circulation and biological productivity in the EEP are largely controlled by the westward-blowing trade winds, that are centered on the intertropical convergence zone (ITCZ), just north of the equator. A stronger southern polar high-pressure zone displaces the westerlies and the trade winds to the north (Flöhn, 1978). Sites 846 through 851 sit beneath the westward-flowing South Equatorial Current (SEC) (Fig. 1A), that is forced by the southeast trade winds (SETWs). The SEC is fed by the Peru Current, which advects cool, nutrient-rich waters from the southeast Pacific into the Galãpagos region, and by the North Equatorial Countercurrent (NECC), which carries eastward the return-flow surface waters from the western equatorial "warm-pool." The intensity of the SEC flow is strongly tied to the strength of the SETWs. Thus, SEC flow is greatest during austral winter, when the SETWs are strongest, and weakest during boreal winter.

The surface-water transport at the equator diverges poleward, as a result of the SEC flow direction and the change in sign of the Coriolis acceleration term at the equator. Continuity necessitates that displaced surface waters be replaced by subsurface waters, which upwell from no more than a 40- to 100 -m depth (Bryden and Brady, 1985). These cool, nutrient-rich subsurface waters, which are separated from the thin overlying mixed layer by the thermocline, fuel biological productivity to one of the highest levels in the open ocean (Chavez and Barber, 1987; Fiedler et al., 1991) (Fig. 1B). The cool upwelled waters along the equator maintain an annual mean sea-surface temperature (SST) that is about $4^{\circ}$ colder than surface waters in both the western equatorial Pacific (WEP) and the northern tropical Pacific (Levitus, 1982). A permanent shallow thermocline exists along the equator, which generally deepens to the west (Hayes et al., 1986). From August to November, the thermocline depth ranges from $40 \mathrm{~m}$ near Sites 846 and 847, to $90 \mathrm{~m}$ at Site 852 (Fiedler et al., 1991). 
Table 3. Equations used to predict dry bulk density from $\% \mathrm{CaCO}_{3}$.

\begin{tabular}{llcc}
\hline Site & Third-order polynomial equation & $r=$ \\
\hline $844 \mathrm{DBD}=0.30134087236+0.0027264361238 \cdot \% \mathrm{CaCO}_{3}+0.0000077131753382 \cdot\left(\% \mathrm{CaCO}_{3}\right)^{2}+0.00000054419604339 \cdot\left(\% \mathrm{CaCO}_{3}\right)^{3}$ & 0.974 \\
$845 \mathrm{DBD}=0.25095552914-0.0013982718521 \cdot \% \mathrm{CaCO}_{3}+0.0001393435227 \cdot\left(\% \mathrm{CaCO}_{3}\right)^{2} \cdot 0.00000054621426935 \cdot\left(\% \mathrm{CaCO}_{3}\right)^{3}$ & 0.975 \\
$846 \mathrm{DBD}=0.36053720313+0.0019558970977 \cdot \% \mathrm{CaCO}_{3}-0.000025255288543 \cdot\left(\% \mathrm{CaCO}_{3}\right)^{2}+0.00000095457703974 \cdot\left(\% \mathrm{CaCO}_{3}\right)^{3}$ & 0.834 \\
847 & $\mathrm{DBD}=0.21123819716+0.0038581436591 \cdot \% \mathrm{CaCO}_{3}-0.000039516004855 \cdot\left(\% \mathrm{CaCO}_{3}\right)^{2}+0.00000089831724772 \cdot\left(\% \mathrm{CaCO}_{3}\right)^{3}$ & 0.837 \\
848 & $\mathrm{DBD}=0.14008003890+0.017345672145 \cdot \% \mathrm{CaCO}_{3}-0.00035154812132 \cdot\left(\% \mathrm{CaCO}_{3}\right)^{2}+0.0000027079298865 \cdot\left(\% \mathrm{CaCO}_{3}\right)^{3}$ & 0.731 \\
849 & $\mathrm{DBD}=0.39062890353+0.0075401622797 \cdot \% \mathrm{CaCO}_{3}-0.00017919899013 \cdot\left(\% \mathrm{CaCO}_{3}\right)^{2}+0.0000018414666774 \cdot\left(\% \mathrm{CaCO}_{3}\right)^{3}$ & 0.757 \\
850 & $\mathrm{DBD}=0.35420974687+0.0061204881477 \cdot \% \mathrm{CaCO}_{3}-0.000098071598016 \cdot\left(\% \mathrm{CaCO}_{3}\right)^{2}+0.0000011068795099 \cdot\left(\% \mathrm{CaCO}_{3}\right)^{3}$ & 0.675 \\
851 & $\mathrm{DBD}=0.34917401870-0.00023933750211 \cdot \% \mathrm{CaCO}_{3}+0.0001012355775 \cdot\left(\% \mathrm{CaCO}_{3}\right)^{2} \cdot 0.00000047891652364 \cdot\left(\% \mathrm{CaCO}_{3}\right)^{3}$ & 0.663 \\
852 & $\mathrm{DBD}=0.20567361613+0.028483990014 \cdot \% \mathrm{CaCO}_{3}-0.00050083236901 \cdot\left(\% \mathrm{CaCO}_{3}\right)^{2}+0.000003503605709 \cdot\left(\% \mathrm{CaCO}_{3}\right)^{3}$ & 0.901 \\
853 & $\mathrm{DBD}=0.08442483545+0.012866864196 \cdot \% \mathrm{CaCO}_{3}-0.00013773950954 \cdot\left(\% \mathrm{CaCO}_{3}\right)^{2}+0.00000078471495227 \cdot\left(\% \mathrm{CaCO}_{3}\right)^{3}$ & 0.403 \\
$854 \mathrm{DBD}=0.29869071863-0.0028181902239 \cdot \% \mathrm{CaCO}_{3}+0.0001587263482 \cdot\left(\% \mathrm{CaCO}_{3}\right)^{2} \cdot 0.000001045390705 \cdot\left(\% \mathrm{CaCO}_{3}\right)^{3}$ & 0.805 \\
\hline
\end{tabular}

Note: Dry bulk density in grams per cubic centimeter.

Sites 852 and 853 are beneath the NECC, generally a region characterized by lower primary productivity (Fig. 1B) and a deeper thermocline resulting from convergence of surface waters. NECC flow is closely coupled with that of the NEC and is strongest in boreal summer, when the ITCZ shifts north. This region is referred to as the "doldrums," where winds are light and precipitation is heavy. Site 854 presently lies beneath the NEC, which is forced by the northeast trade winds. Productivity levels here are also generally low (Fig. 1B). Sites 844 and 845 , respectively, are in, and near, the Costa Rica Dome, where seasonal productivity levels are extremely high because of a thermocline doming that results from the curl of the local wind stress (Hofmann, 1981).

The subsurface water mass along the equator is the Equatorial Undercurrent (EUC), which flows from west to east, as a narrow ribbon between $2^{\circ} \mathrm{N}$ and $2^{\circ} \mathrm{S}$ (Lukas, 1986). The nutrient-rich EUC supplies the upwelling region in the equatorial Pacific and along coastal Peru (Wooster and Gilmartin, 1961; Wyrtki, 1967; Farrell et al., this volume). Deep waters in the EEP basins are described by Lyle et al. (this volume). The geochemistry of these waters differs among the basins, as clearly demonstrated by Lyle et al. (this volume) and Mix et al. (this volume).

\section{Tectonic Setting}

The generalized tectonic setting of the EEP is presented in Figure 1C. The sites are divided into three regions on three lithospheric plates. Sites 844 and 845 are on the Cocos Plate within the Guatemala Basin. Sites 846 and 847 lie within the Galãpagos region (and respectively the Bauer and Peru Basins) on the Nazca Plate. The remaining sites (848-854), comprising the $110^{\circ} \mathrm{W}$ equatorial transect, are on the Pacific Plate in the Pacific Basin. This tectonic setting and its evolution through time are complex, and the reader is referred elsewhere for details (e.g., van Andel et al., 1975; Hey, 1977; Hey et al., 1977; Mammerickx and Naur, 1988; Wadge and Burke, 1983; Cox and Engebretson, 1985; Duncan and Clague, 1985; DeMets et al., 1990).

The tectonic plates, and thus the drill sites, have moved away from the East Pacific Rise over time. In general, the $110^{\circ} \mathrm{W}$ transect sites have moved to the northwest, and the others have moved eastward. To reconstruct the migration of the drill sites through time, we adopted the backtracked paths presented by Pisias et al. (this volume) (Fig. 1D). These differ somewhat from the paths presented by Lyle et al. (this volume) and from those in the Leg 138 Initial Results volume (Mayer, Pisias, Janecek, et al., 1992). Reconstruction of the paleopositions beyond $10 \mathrm{~m} . \mathrm{y}$. grows progressively tenuous in any EEP reconstruction because of the uncertainty in the poles of rotation, the angular rotation rates, and in the timing and location of ridge jumps. Nevertheless, we show the backtracks at 1-m.y. increments (e.g., 0, 1, 2, $3 \mathrm{Ma}$, etc.) in Figure 1D.

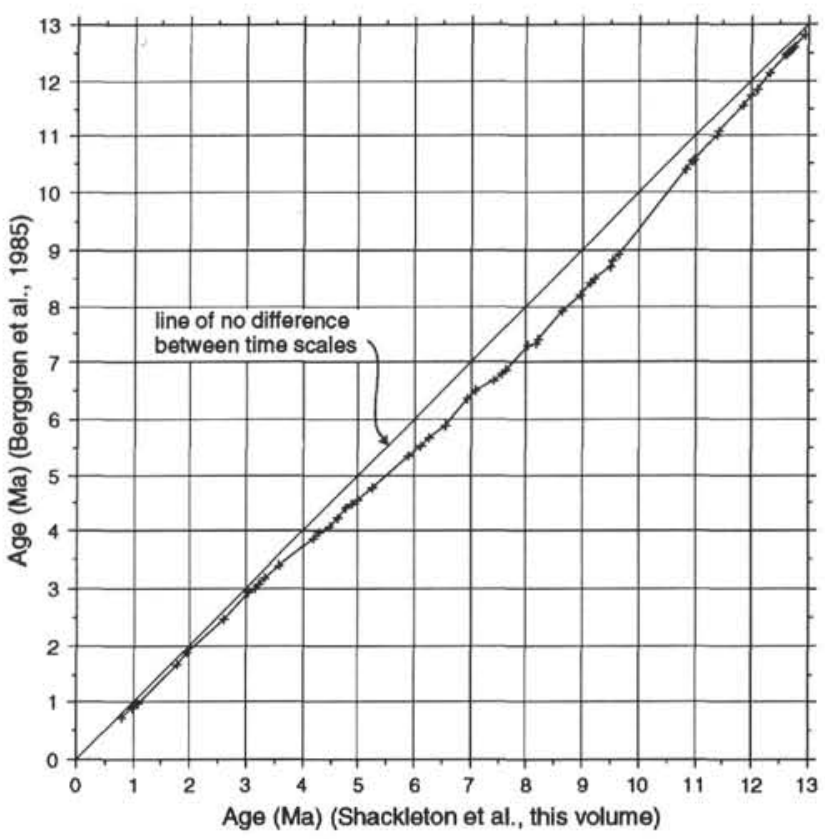

Figure 4. Graphic comparison between Berggren et al.'s (1985) time scale and that of Shackleton et al. (this volume), adopted here, shows the ages assigned to the 52 magnetic reversals and anomalies extending back to, and including, C5AAn ( $\mathrm{t}$ ). Over this interval, the Shackleton et al. ages are older by 50 to 824 k.y., around a mean age difference of 407 k.y.

The modern tectonic setting is significantly different from that in the Miocene or even the Pliocene. For example, a seaway existed between the Pacific and the Atlantic (proto-Caribbean) oceans over much of the Cenozoic. Ocean circulation was significantly different when the seaway was open (Maier-Reimer et al., 1990), as discussed below. Tectonic closure of the Indonesian Passage, between 8.7 and $10.5 \mathrm{Ma}$, probably created, or at least intensified, the EUC (Leinen, 1979; Kennett, 1985).

\section{RESULTS AND DISCUSSION}

\section{Calcareous Nannofossil Assemblages}

Calcareous nannofossils are numerous and well preserved in the EEP, with the highest abundances and best preservation occurring at the equatorial sites in the $110^{\circ} \mathrm{W}$ transect (Figs. 5 and 6). In addition, these nannofossils are minimally etched and show only minor over- 


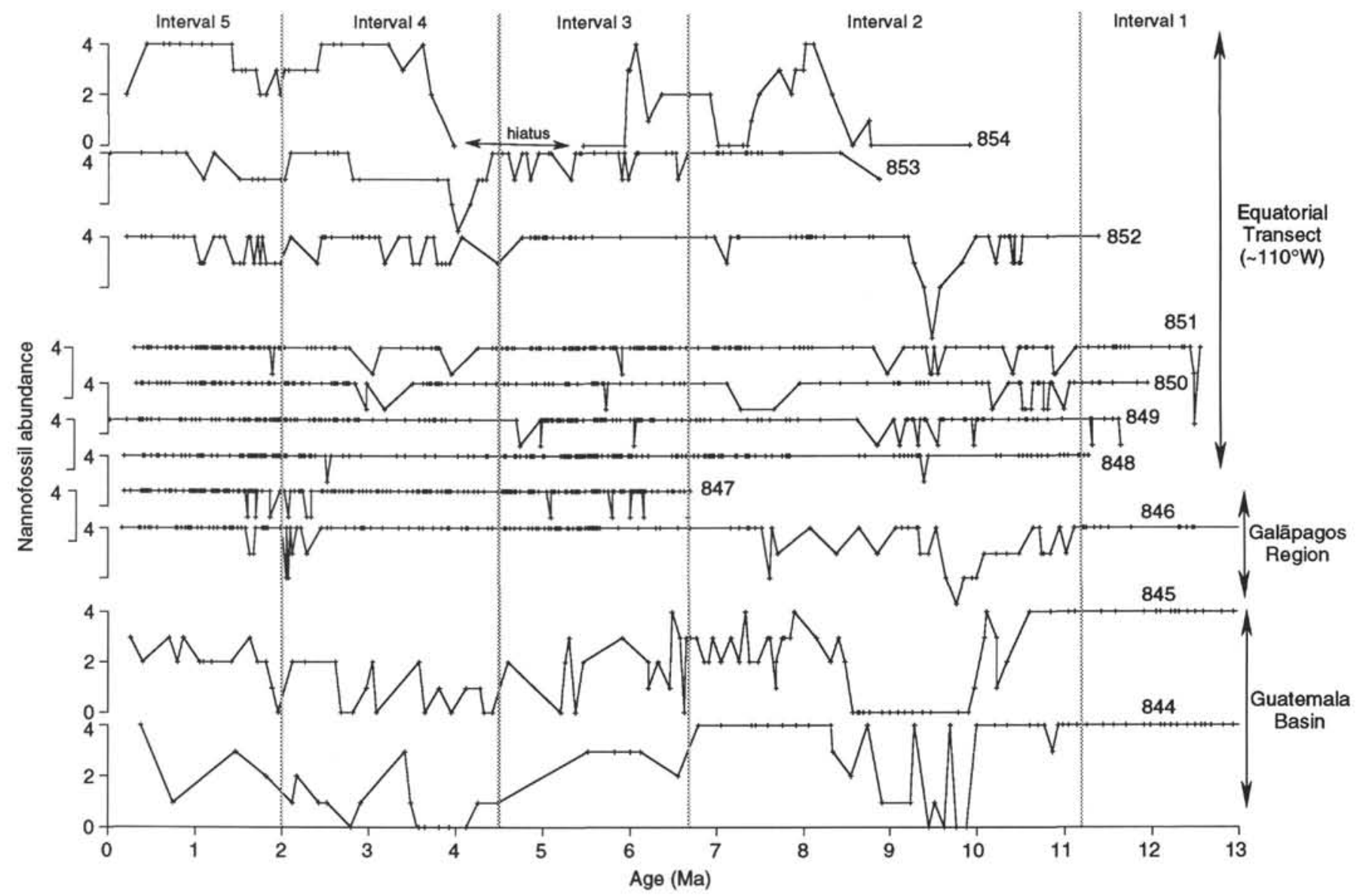

Figure 5. The semiquantitative abundance of nannofossils in the floral assemblage vs. age in the Leg 138 sites. The abundance scale ranges from 0 to 4 , with higher values indicating greater abundance. The record is subdivided into five intervals.

growth, if any at all (Figs. 7 and 8). Abundant and well-preserved floral assemblages reflect a combination of high production, rapid flux from the surface waters to the seafloor, relatively swift burial, enhanced preservation, and minimal recrystallization within the sediment column. Nannofossil assemblages characterized by low abundances, poor preservation, discernible etching, and overgrowth were more frequently observed in the Guatemala Basin and along the northern portion of the $110^{\circ} \mathrm{W}$ transect (Sites 853 and 854 ), where $\mathrm{CaCO}_{3}$ accumulation has been slow. In general, a close correspondence exists among the four different characterizations (abundance, preservation, etching, and overgrowth) of the nannofossil assemblages. Samples having low nannofossil abundances generally show poor preservation, greater etching, and more overgrowth. Despite the close correspondence, we observed more structure and higherfrequency variability in preservation than in the other characterizations. For example, at Site 848, nannofossil abundance was nearly always the highest value (four), whereas the preservation record clearly shows a gradual increase in preservation from 11 to $0 \mathrm{Ma}$ with superimposed higher frequency changes.

The nannofossil record of the last $13 \mathrm{~m} . \mathrm{y}$. was divided into five distinct intervals: (1) 13-11.2 Ma, (2) 11.2-6.7 Ma, (3) 6.7-4.5 Ma, (4) 4.5-2 Ma, and (5) 2-0 Ma. Intervals 2 and 4 were periods when nannofossil abundance was low and preservation was notably reduced at many sites. These intervals represent times when bottom waters were particularly corrosive to carbonate and/or when nannofossil productivity was lower. The other intervals (1,3, and 5) appear to have been periods of high nannofossil flux and/or enhanced preservation. For example, nearly all sites showed distinctive increases in nannofossil abundance and preservation and decreases in etching and overgrowths during the Quaternary $(2-0 \mathrm{Ma})$.

In Miocene Interval 2, nannofossil abundance and preservation values as low as one, and even zero, are recorded in the Guatemala Basin, the Galãpagos region, and along the $110^{\circ} \mathrm{W}$ transect. The lowest values of the entire record cluster near $9.5 \mathrm{Ma}$. The abundance values in the equatorial sites along the $110^{\circ} \mathrm{W}$ transect (Sites 848 851 ) decrease by less, from four to three, but this interval clearly is distinguished from the others in terms of the greater frequency of lower values. Dissolution was particularly severe in the Guatemala Basin sites, where many samples are barren.

The effects of dissolution in Pliocene Interval 4 are clearly noticeable in the Guatemala Basin, where abundance and preservation of nannofossils are among the lowest of any time or place within the late Neogene record. This interval at the other sites is marked by declines in abundance and preservation values, from four to three or two. In addition, a greater tendency for etching and overgrowth is found in this interval than in Intervals 1, 3, and 5.

Periods when nannofossils were abundant and well preserved are less easily discerned than periods that experienced strong dissolution. However, Interval 3 was generally a period of good preservation. The nannofossils in this interval, spanning from the late Miocene to the early Pliocene, are well preserved and less etched at all sites except Site 854 , which has a hiatus over much of this interval. The clearest nannofossil trend common to all sites extends from 2 to $0 \mathrm{Ma}$ and is characterized by increases in abundance and preservation and decreases in etching and overgrowths. Compared to the Pliocene and much of the Miocene, the Quaternary appears to be a time when 


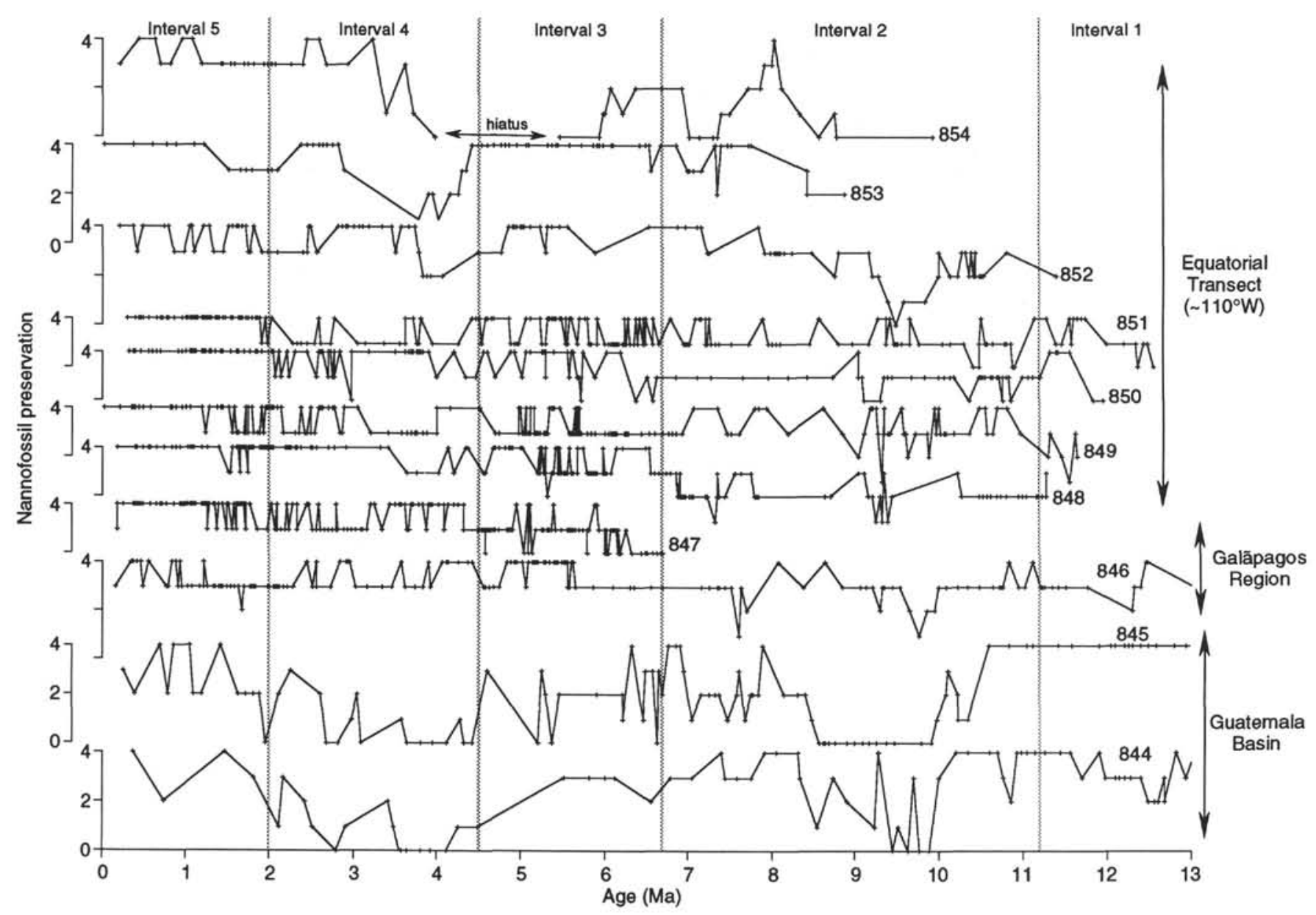

Figure 6. The semiquantitative preservation state of nannofossils in the floral assemblage vs. age in the Leg 138 sites. Higher values indicate better preservation.

bottom waters were less corrosive and/or nannofossil productivity and flux were higher. This pattern matches that observed in $\% \mathrm{CaCO}_{3}$ records farther to the west, in the central equatorial Pacific (CEP), where the $\% \mathrm{CaCO}_{3}$ of the Quaternary sediments was significantly higher than that of the Pliocene sediments (Farrell and Prell, 1991).

One of the most important uses of the nannofossil data was for constraining the interpretation of bulk-sediment composition changes, particularly in $\% \mathrm{CaCO}_{3}$. As we shall see, the nannofossil data helped us to discriminate among dilution, dissolution, and production as the dominant control of sedimentary $\% \mathrm{CaCO}_{3}$ in this region.

\section{General Characteristics of Sediment Composition and Flux}

Figures 9 through 14 show time series of $\mathrm{CaCO}_{3}$, opal, and terrigenous concentration and flux from 0 to $13 \mathrm{Ma}$. In all but three sites $(844,845$, and 854$)$, the sediment composition is dominated by $\mathrm{CaCO}_{3}$, indicating that nannofossils and foraminifers constitute the primary biogenic flux. Opal concentrations (except in the northern $110^{\circ} \mathrm{W}$ transect sites) are generally between $10 \%$ and $20 \%$, with larger values occurring in the Galãpagos region, where present-day productivity is highest (Berger et al., 1987). Most of the opal is in the form of diatom frustrules, especially where discrete beds of Thalassiothrix were rapidly deposited as mats (Kemp and Baldauf, 1993). Radiolarians are the other major opal component and they dominate in the off-equatorial sites, where productivity levels are lower and carbonate dissolution is greater. Terrigenous concentrations are great- est at the sites nearest the continents (Sites 844 and 845) and farthest from the equatorial high-productivity region (Site 854 ), where dissolution of biogenic material concentrates the clay minerals. The mean estimate for the \%terrigenous is greater than $40 \%$ in these lowsedimentation-rate regions, as compared to less than $25 \%$ at all other sites. Riverine flux dominates the terrigenous fraction at the Guatemala Basin sites, whereas eolian flux is proportionally greater in the $110^{\circ} \mathrm{W}$ transect sites (Hovan, this volume).

The MARs of biogenic sediments are greatest beneath surface waters of highest productivity and, thus, are greatest along the equatorial divergence and within the "cold tongue" (Toggweiler et al., 1991) of nutrient-rich waters south of Galãpagos (Site 846). Although seasonal-productivity levels in the Costa Rica Dome region (Site 844) are extremely high for an open-ocean site, biogenic MARs were lower in this region than in the equatorial regions, even during the past $1 \mathrm{~m} . \mathrm{y}$., when Site 844 was situated directly beneath the dome. $\mathrm{CaCO}_{3}$ and opal MARs increase toward the equator, and during the past 13 m.y., the highest mean values of both were found in the $110^{\circ} \mathrm{W}$ transect equatorial sites, not in the Galãpagos region as might be expected. Our estimates of terrigenous MAR suggest that the highest rates were in the Galãpagos region and along the $110^{\circ} \mathrm{W}$ transect sites near the equator, rather than in the Guatemala Basin. We are suspicious of this result, because of our likely overestimation of the \%terrigenous content. Instead, we think that the highest rates of terrigenous MAR have been in the Guatemala Basin. Along the $110^{\circ} \mathrm{W}$ transect, Hovan (this volume) shows that the highest terrigenous concentrations and MARs were at the northernmost sites. 


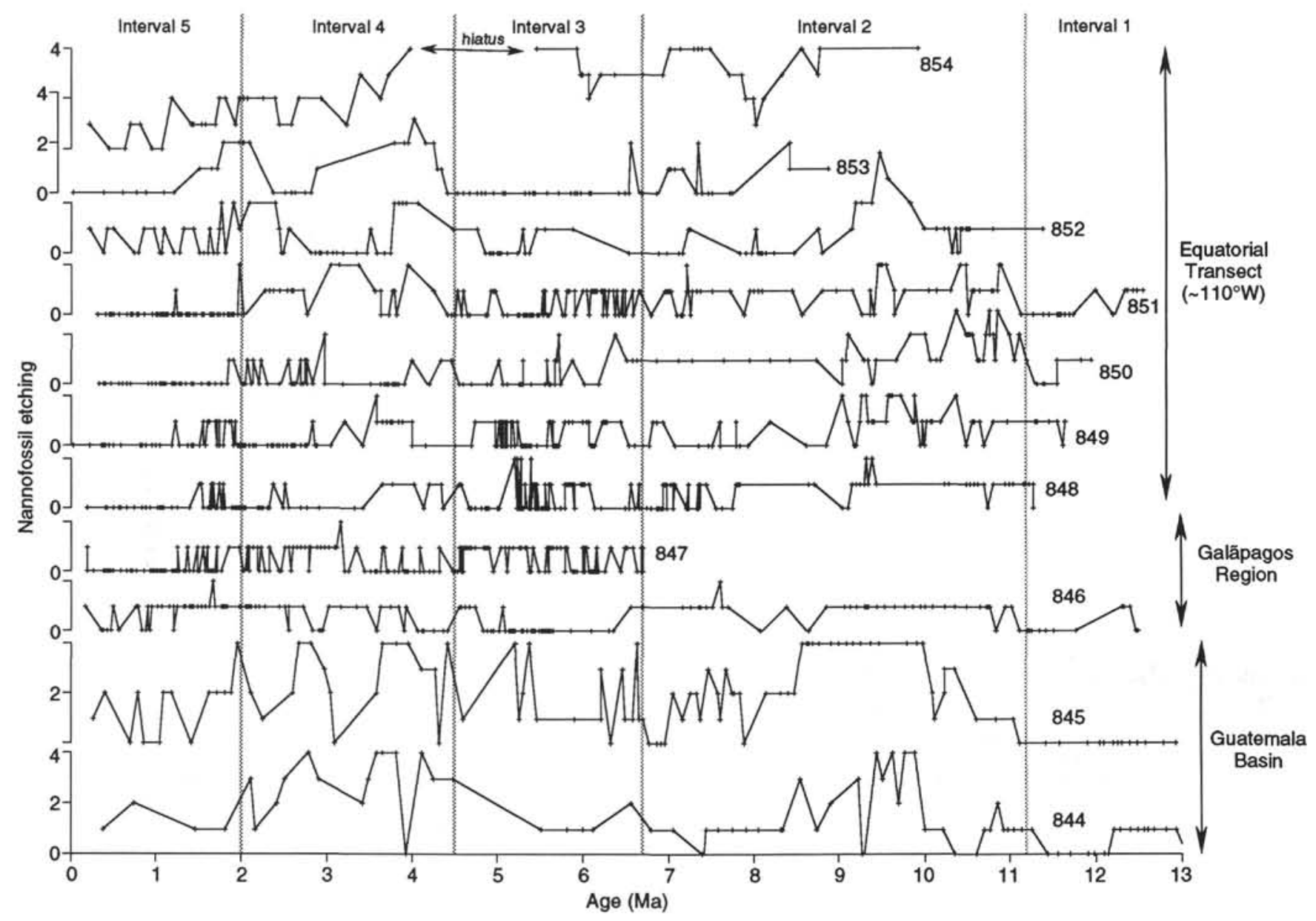

Figure 7. The semiquantitative evaluation of the degree of etching of the nannofossils in the floral assemblage vs. age in the Leg 138 sites. Higher values indicate increased etching.

\section{Temporal Variability}

Large changes in composition and flux were observed in sediments over the past 13 m.y. (Figs. 9-14). The major changes, and many minor ones, are easily correlated among most of the sites, mostly because of the internally consistent age models derived for this leg (Shackleton et al., this volume). Variations in sediment composition and flux reflect not only the dynamics of ocean circulation and productivity, but also the slow tectonic drift of the sites into and out of the various equatorial oceanographic and climatic regimes.

We summarized temporal change in sedimentation since $13 \mathrm{Ma}$ by subdivision into five distinct intervals: (1) 13-11.2 Ma, (2) 11.2-9.5 $\mathrm{Ma}$, (3) 9.5-6.7 Ma, (4) 6.7-4.5 Ma, and (5) 4.5-0 Ma. These intervals were chosen because they represent distinct breaks in the sedimentary record and because of the similarity of these intervals to the nannofossil subdivisions. During the first interval (13-11.2 Ma), $\mathrm{CaCO}_{3}$ concentrations and MARs were moderately high, especially at Site 844 , which was closer to the equator at this time. In fact, $\mathrm{CaCO}_{3}$ sedimentation dominated Sites 844,845 , and 846 back to the earliest portion of these records, near $18 \mathrm{Ma}$ (Appendixes A and B; Mayer, Pisias, Janecek, et al., 1992). $\mathrm{CaCO}_{3}$ concentrations at these sites were greater than $70 \%$, and fluxes were 6 to 20 times higher than opal fluxes between 17 and 11.2 Ma. Nevertheless, a few intervals in Site 844 contain high \%opal values, indicative of diatom-rich beds. These may represent rapid, relatively ephemeral events of high opal flux, but documentation of this will require finer-resolution age control.

During the second interval ( 11.2 to about $9.5 \mathrm{Ma}$ ), $\mathrm{CaCO}_{3}$ concentrations and fluxes significantly declined in all records, in a series of steps, with minima centered at about 10.9, 10.3, and 9.5 Ma. Not sur- prisingly, the \%opal peaked where $\% \mathrm{CaCO}_{3}$ declined, particularly at 10.9 and $9.5 \mathrm{Ma}$. Some of the highest opal percentages in the entire record were observed in this interval, especially at Site 850 , which was located near $1^{\circ} \mathrm{S}$ at this time (Fig. 10). These extremely high values generally reflect measurements on sediments that are almost entirely composed of diatoms. The intervals of elevated \%opal are often times of elevated opal MAR, suggesting greater opal production. The interval from 11.2 to about $9.5 \mathrm{Ma}$ is characterized by instability and by pronounced swings in the dominance of carbonate vs. opal accumulation, which possibly reflect shifts in surface ecology. These swings, and the sharp decline in $\mathrm{CaCO}_{3}$ flux and MAR, also signal the initiation of the "carbonate crash" (Lyle et al., this volume).

The lowest sedimentation rates, $\% \mathrm{CaCO}_{3}$, and $\mathrm{CaCO}_{3}$ MARs observed at many of the Leg 138 sites occurred during the "carbonate crash" centered at about $9.5 \mathrm{Ma}$, which marks the beginning of the third interval. This was one of the greatest regional events in the EEP(Lyle et al., this volume). The $\% \mathrm{CaCO}_{3}$ and $\mathrm{CaCO}_{3}$ flux values at Sites 844 , 845 , and 846 declined to near zero between 9.7 and $9.5 \mathrm{Ma}$ (Fig. 15). Values in the $110^{\circ} \mathrm{W}$ transect sites appear to have declined more slowly, reaching bottom by about $9.5 \mathrm{Ma}$. This interval of declining $\mathrm{CaCO}_{3}$ sedimentation coincides with the interval of poorly preserved nannofossil assemblages (Fig. 6), attesting to the severity of the dissolution. Recovery from the crash began at about $9.4 \mathrm{Ma}$. After a brief dissolution event at $8.9 \mathrm{Ma}$, recovery resumed, even in the Guatemala Basin. Recovery at Sites 844 and 845 continued until about $8 \mathrm{Ma}$, but $\mathrm{CaCO}_{3}$ accumulation essentially ceased after that. These sites drifted to the northwest, out of the region influenced by equatorial divergence and into the NECC. Today, Site 844 is just above the regional CCD at $\sim 3600 \mathrm{~m}$ (Lyle et al., this volume), whereas Site 845 is just below the 


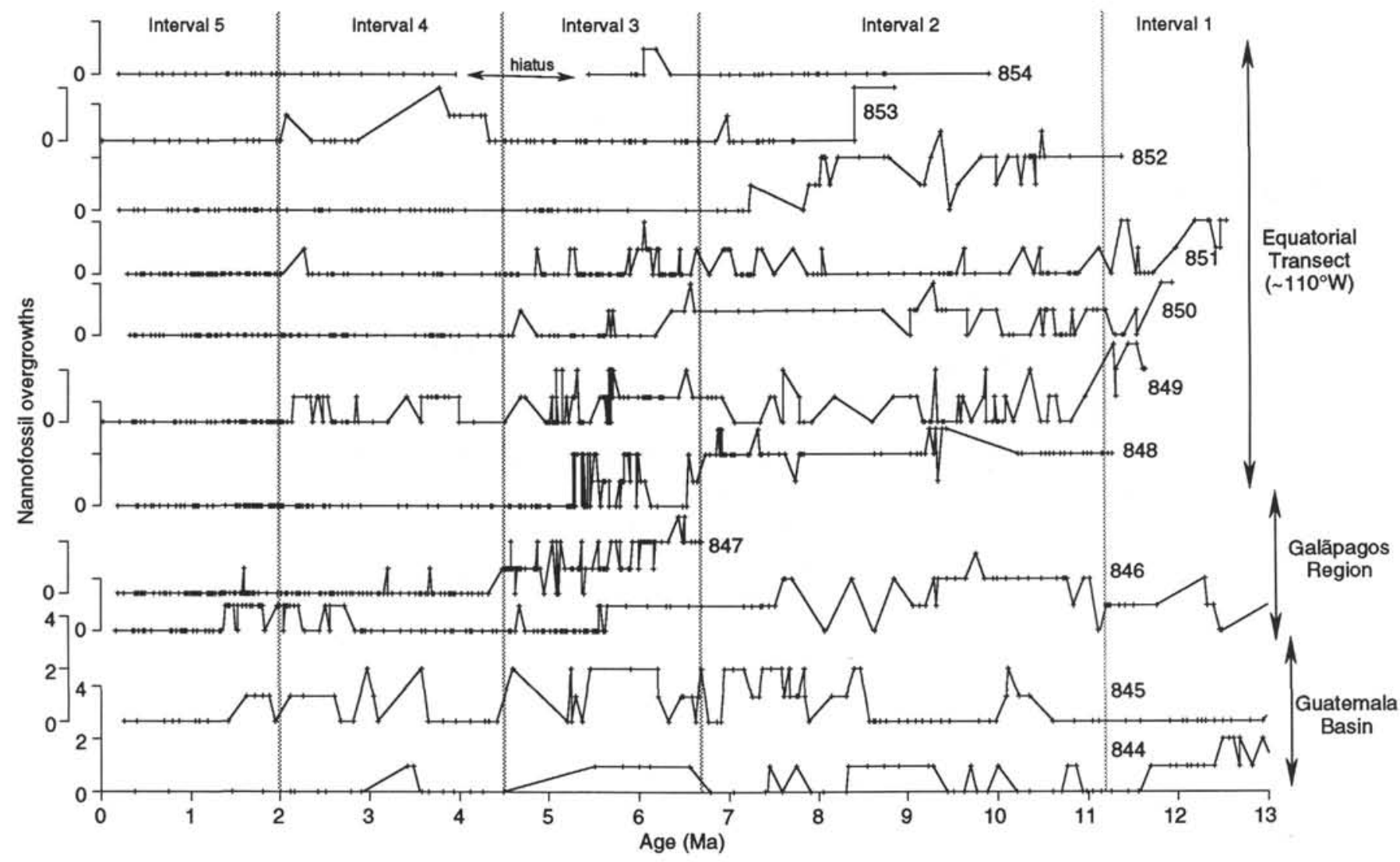

Figure 8 . The semiquantitative evaluation of calcite overgrowth observed on the nannofossils in the floral assemblage vs. age in the Leg 138 sites. Higher values indicate increased overgrowth.

CCD. At the other sites, levels of $\% \mathrm{CaCO}_{3}$ and $\mathrm{CaCO}_{3}$ flux returned to pre-crash levels between 8 and $7 \mathrm{Ma}$. A particularly sharp rise in $\mathrm{CaCO}_{3}$ accumulation occurred at Site 846 between 7.5 and $7 \mathrm{Ma}$ (Fig. 15).

The distinguishing characteristic of the fourth interval (between 6.7 and $4.5 \mathrm{Ma}$ ) is the extremely high rates of biogenic accumulation, particularly at the sites nearest the equator. The mean sediment fluxes during this $\sim 2-$ m.y. "biogenic bloom" were higher than those in any other 2-m.y. interval in the records from all sites (except Sites 844, 845, and 854 ). This interval is characterized by highly variable fluxes as well as by high mean values of all parameters measured. Particularly high opal fluxes, often in excess of $2 \mathrm{~g} / \mathrm{cm}^{2} / \mathrm{k}$.y., were recorded at 6.6 , $6.0,5.7$, and $4.6 \mathrm{Ma}$ at Sites 849 through 851 . This time interval was the last in which higher opal fluxes occurred in the western sites, rather than in the Galãpagos region (Sites 846 and 847). Terrigenous accumulation rates were also high in this interval, but again, we are suspicious of these values because \%terrigenous values have been overestimated. Finally, although large fluxes were occurring at most sites, erosion removed sediment at Site 854, producing a hiatus from 5.9 to $3.7 \mathrm{Ma}$ (between 19.93 and $19.50 \mathrm{rmcd}$ ). Based on the timing of this hiatus, we interpreted it as hiatus "NH7" (Keller and Barron, 1983).

Brief intervals of extremely high opal accumulation (occasionally in excess of $2 \mathrm{~g} / \mathrm{cm}^{2} / \mathrm{k}$.y.) occurred between 5 and $7 \mathrm{Ma}$ and may have been linked to widespread deposition of laminated diatom mats (Kemp and Baldauf, 1993). Although a careful comparison of the diatom mats and the opal concentration and flux data is incomplete, we were able to correlate between opal MAR and laminations in some intervals. For example, the interval of high opal MAR between 5.75 and $5.78 \mathrm{Ma}$ at Sites 847,849 , and 850 contains well-laminated diatom mats at Sites 847 and 849 . Curiously, no mats of any kind were reported anywhere in the same interval at Site 850 (Kemp and Baldauf, this volume), despite the proximity to Site 849 and the fact that the opal MARs were highest at Site 850 . Also puzzling is why no mats, or even mat frag- ments, were observed at Site 851 at this time. Both Sites 850 and 851 were closer to the equator, and thus presumably the locus of mat formation (Kemp and Baldauf, 1993), than Site 847, where welllaminated mats were observed. Another apparent inconsistency is that mats were observed in the interval of high opal MAR between 6.50 and $6.63 \mathrm{Ma}$ at Site 849 and also at Site 850 , but not at Site 851 nor at Site 847 , although the sedimentary record at the latter extends to $6.7 \mathrm{Ma}$ (rather than $6 \mathrm{Ma}$, as indicated by Fig. 1 of Kemp and Baldauf, 1993).

Following the great deposition during the "biogenic bloom," sedimentation rates in the EEP declined to moderate levels and remained relatively stable during the fifth interval (between 4.5 and $0 \mathrm{Ma}$ ). Two interesting changes were observed in this interval. First, the locus of maximum opal MAR shifted from the $110^{\circ} \mathrm{W}$ transect sites to the Galãpagos region at about $4.4 \mathrm{Ma}$, as discussed below. Second, elevated opal percentages and MARs occurred in the Galãpagos region between 3 and $1.5 \mathrm{Ma}$, with a distinct maximum at about $1.9 \mathrm{Ma}$. This maximum corresponds to a minimum in $\% \mathrm{CaCO}_{3}$ and $\mathrm{CaCO}_{3}$ flux, discussed in greater detail by Murray et al. (this volume).

We noted the absence of distinct shifts in the sedimentary response to changes in the cryosphere, and thus presumably global climate conditions, at about 2.7 and $0.9 \mathrm{Ma}$. These times demarcated, respectively, the initiation of significant Northern Hemisphere glaciation (Shackleton et al., 1984; Sikes et al., 1993) and the 100-k.y. cyclicity of late Pleistocene ice sheet waxing and waning (Prell, 1982; Start and Prell, 1984). These events, and the inferred changes in global ice volume, were clearly identified in several Leg 138 oxygen isotope records (e.g., Ravelo et al., this volume; Farrell et al., this volume; Mix et al., this volume; and Shackleton et al., this volume). Furthermore, $100-\mathrm{k}$.y. variability in $\% \mathrm{CaCO}_{3}$ and \%opal during the past 0.9 m.y. was observed in the detailed record from Site 847 (Murray et al., this volume). Nevertheless, no distinct or large shift is apparent toward higher or lower sediment accumulation rates in the EEP that 


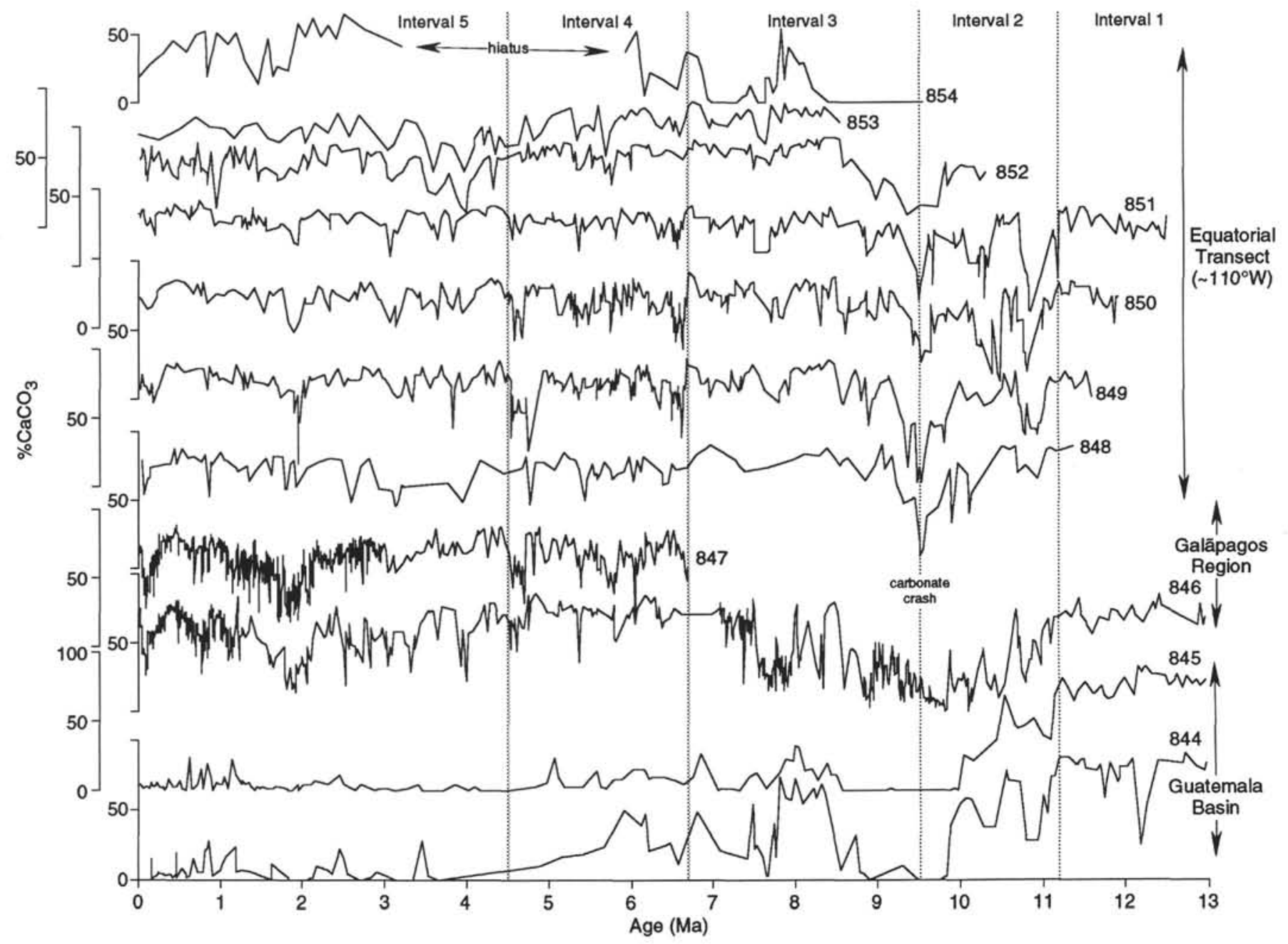

Figure 9. Percentage of $\mathrm{CaCO}_{3}$ in bulk sediments vs. age in the Leg 138 sites.

corresponds to these events. This lack of correspondence suggests that the gross sedimentation patterns in the EEP were not strongly affected by these cryosphere changes.

\section{Spatial Variability}

Sedimentation patterns in the EEP should be examined in a spatial as well as a temporal framework because of the sharp oceanic and climatic gradients in this region, and the complicated tectonic framework that resulted in not only different absolute and relative positions of the drill sites through time, but also changes in ocean circulation from ocean seaway openings and closings (e.g., Panama and Indonesia). We calculated mean values of all sediment concentrations and fluxes for 1-m.y. time intervals at seven critical times in the evolution of the EEP (Table 4). Several of these intervals were chosen to correspond to those selected by van Andel et al. (1975) to facilitate comparisons of sedimentary patterns between the EEP and the CEP. Sedimentation maps were constructed from these values for the following intervals: $11-12 \mathrm{Ma}, 10-11 \mathrm{Ma}, 9-10 \mathrm{Ma}, 8-9 \mathrm{Ma}, 5-6 \mathrm{Ma}$, 3-4 Ma, and 0-1 Ma (Figs. 16-22). For comparative purposes, the maps are presented in reverse chronology (youngest to oldest), as in van Andel et al. (1975). Time series of these mean MAR values are presented in Figure 23.

\section{0-1 Ma}

Maps of the 0-1 Ma interval (Fig. 16) are generally similar to those showing Holocene (Lyle, 1992) and Quaternary (Snoeckx and
Rea, this volume; Leinen, 1979) sedimentation patterns. Highest concentrations of $\mathrm{CaCO}_{3}$ are beneath the equator, and farthest from the continental margin, whereas the reverse is true of terrigenous and opal concentrations. The isopleths converge in specific regions when converted to MAR. Highest fluxes of both $\mathrm{CaCO}_{3}$ and opal occur in a relatively narrow equatorial band centered between $0^{\circ}$ and $3^{\circ} \mathrm{S}$. The opal concentrations and fluxes are higher at Sites 844 and 845 than at the $110^{\circ} \mathrm{W}$ transect sites at the same approximate latitude (Sites 853 and 854 ). This result may be attributed to higher opal production in the Costa Rica Dome region. The sediments in the Galãpagos region (Site 846) have the highest opal accumulation and concentration, and the values are twice those observed in the western transect. The reverse is true of the $\mathrm{CaCO}_{3}$ maximum, though the east-west gradient in flux and concentration was less than a factor of two. The flux at transect Site 849 was only $25 \%$ higher than that at Sites 846 or 847 . The spatial distribution of terrigenous concentration shows highest values near the continental margin and farthest from the equator, as does the terrigenous MAR distribution, although more complicated patterns can be observed in the $110^{\circ} \mathrm{W}$ transect.

\section{$3-4 M a$}

During the mid-Pliocene (3-4 Ma), the overall MARs were lower than during the late Pleistocene, but the sediment distribution patterns (Fig. 17) were not significantly different. Small changes include a steepening of the opal MAR gradient toward the equator and decreases in the $\% \mathrm{CaCO}_{3}$ and $\mathrm{CaCO}_{3}$ MAR. No evidence of high pro- 


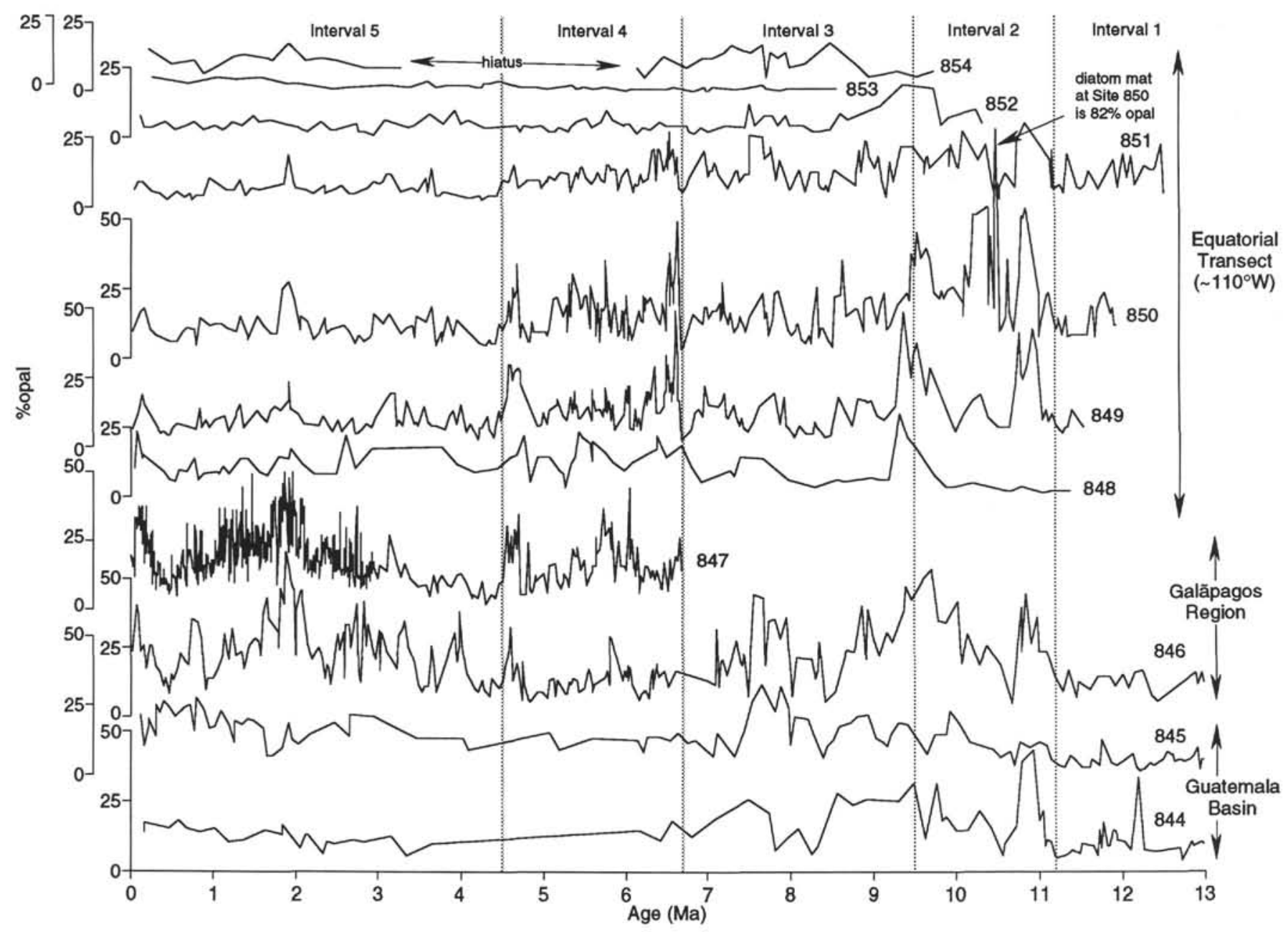

Figure 10. Percentage of opal in bulk sediments vs. age in the Leg 138 sites.

ductivity under the Costa Rica Dome was observed because (1) this oceanic feature was weaker or did not exist at this time; (2) residual, surface-water flow of Caribbean waters through the Panamanian seaway prevented dome formation; or (3) Sites 844 and 845 were situated southwest of the upwelling region, outside the area of influence. The terrigenous MAR distribution shows a distinctly different spatial pattern, with highest values along the equator, but this is likely an artifact of overestimated \%terrigenous values.

\section{5-6 Ma}

The 5-6 Ma interval was marked by significantly higher accumulation rates (Fig. 18). Mean $\mathrm{CaCO}_{3}$ concentrations increased at the offequatorial sites by up to $23 \%$, whereas the $\% \mathrm{CaCO}_{3}$ change at equatorial sites was minor. Opal contents remained about the same, except in the western equatorial sites, where they increased slightly. The concentration of terrigenous sediments decreased at every site, but especially so at off-equatorial sites, where decreases of as much as $30 \%$ were observed. On average, the $\mathrm{CaCO}_{3} \mathrm{MAR}$ increased at this time by $360 \%$ and the opal MAR by $270 \%$, compared to those during the midPliocene time slice (3-4 Ma) (Table 4). Our values for opal MARs are somewhat higher than those observed by Leinen (1979) for the 4- to 7-Ma interval, most likely because of our higher sedimentation rates. Despite the overall increase in MAR, the spatial patterns of sedimentation remained the same, with two key exceptions. As during more recent periods, the highest accumulation occurred within a narrow belt along the equator. However, during the interval from 5 to $6 \mathrm{Ma}$, the highest opal MAR was in the $110^{\circ} \mathrm{W}$ equatorial sites, rather than in the Galãpagos region. The other notable difference was a steepening of the latitudinal gradient in sediment accumulation. Compared to the subsequent interval (3-4 Ma), and especially the previous interval (8-9 $\mathrm{Ma}$ ), the greatest increases in MAR during the interval from 5 to $6 \mathrm{Ma}$ occurred at the sites nearest the equator. Off-equatorial sites showed progressively smaller MAR increases with increasing latitude. A hiatus, indicating nondeposition or erosion, was identified at this interval in Site 854 , the northernmost site along the $110^{\circ} \mathrm{W}$ transect.

\section{8-9 Ma}

Figure 19 shows the sedimentary patterns that evolved between 8 and $9 \mathrm{Ma}$, during the recovery from the carbonate crash (9-10 Ma). Although strong trends paralleled the equator, as in other intervals, a marked steepening was seen in the east-west gradient in biogenic MAR at 8 to $9 \mathrm{Ma}$. Comparison of Site 846 with the $110^{\circ} \mathrm{W}$ transect sites near the equator indicates significantly lower MARs in the east, compared to those at subsequent times. The steepening of the $\mathrm{CaCO}_{3}$ MAR gradient was especially distinct. During the 8- to 9-Ma interval, a sixfold difference in $\mathrm{CaCO}_{3}$ MAR occurred between Sites 846 and $850\left(0.35\right.$ and $2.17 \mathrm{~g} / \mathrm{cm}^{2} / \mathrm{k}$.y., respectively), whereas the difference was about onefold in all subsequent intervals.

\section{9-10 Ma}

The 9-10 Ma interval is distinguished by an enormous decline in $\% \mathrm{CaCO}_{3}$ and a smaller decrease in $\mathrm{CaCO}_{3}$ MAR (Figs. 15 and 20). 
Table 4. Mean sediment content and MAR over selected time intervals.

\begin{tabular}{|c|c|c|c|c|c|c|c|}
\hline Site & $\begin{array}{l}\text { Interval } \\
(\mathrm{Ma})\end{array}$ & $\begin{array}{c}\mathrm{CaCO}_{3} \\
(\%)\end{array}$ & $\begin{array}{l}\text { Opal } \\
(\%)\end{array}$ & $\begin{array}{c}\text { Terrigenous } \\
\text { (\%) }\end{array}$ & $\begin{array}{c}\mathrm{CaCO}_{3} \\
\mathrm{MAR} \\
\left(\mathrm{g} / \mathrm{cm}^{2} / \mathrm{k} . \mathrm{y} .\right)\end{array}$ & $\begin{array}{c}\text { Opal } \\
\text { MAR } \\
\left(\mathrm{g} / \mathrm{cm}^{2} / \mathrm{k} . \mathrm{y} .\right)\end{array}$ & $\begin{array}{l}\text { Terrigenous } \\
\text { MAR } \\
\left(\mathrm{g} / \mathrm{cm}^{2} / \mathrm{k} \text {.y. }\right)\end{array}$ \\
\hline \multirow[t]{8}{*}{844} & $0-1$ & 7.74 & 15.90 & 74.14 & 0.03 & 0.07 & 0.31 \\
\hline & $3-4$ & 4.51 & 9.55 & 89.73 & 0.01 & 0.01 & 0.09 \\
\hline & $5-6$ & 27.77 & ND & ND & 0.08 & ND & ND \\
\hline & $8-9$ & 35.92 & 18.16 & 44.78 & 0.14 & 0.06 & 0.14 \\
\hline & $9-10$ & 9.10 & 23.05 & 67.84 & 0.04 & 0.08 & 0.25 \\
\hline & $10-11$ & 54.99 & 19.90 & 27.89 & 0.59 & 0.19 & 0.25 \\
\hline & $11-12$ & 77.08 & 10.23 & 13.11 & 2.27 & 0.28 & 0.35 \\
\hline & $0-17.5$ & 45.90 & 12.53 & 31.50 & 1.16 & 0.21 & 0.31 \\
\hline \multirow[t]{8}{*}{845} & $0-1$ & 5.41 & 21.07 & 74.05 & 0.03 & 0.13 & 0.46 \\
\hline & $3-4$ & 2.33 & 13.32 & 85.76 & 0.01 & 0.03 & 0.21 \\
\hline & $5-6$ & 7.73 & 12.72 & 73.25 & 0.03 & 0.05 & 0.28 \\
\hline & $8-9$ & 16.58 & 73.38 & 0.04 & 0.08 & 0.38 & \\
\hline & $9-10$ & 0.72 & 14.89 & 84,36 & 0.00 & 0.06 & 0.34 \\
\hline & $10-11$ & 42.39 & 10.27 & 47.33 & 0.26 & 0.06 & 0.26 \\
\hline & $11-12$ & 69.59 & 5.68 & 24.43 & 0.98 & 0.08 & 0.32 \\
\hline & $0-16.6$ & 35.89 & 10.54 & 43.74 & 0.77 & 0.11 & 0.36 \\
\hline \multirow[t]{8}{*}{846} & $0-1$ & 60.46 & 21.28 & 17.49 & 1.52 & 0.49 & 0.39 \\
\hline & $3-4$ & 54.64 & 22.34 & 22.61 & 1.29 & 0.48 & 0.51 \\
\hline & $5-6$ & 70.18 & 14.04 & 14.94 & 3.27 & 0.63 & 0.64 \\
\hline & $8-9$ & 34.60 & 21.63 & 38.39 & 0.35 & 0.19 & 0.34 \\
\hline & $9-10$ & 22.84 & 37.93 & 36.67 & 0.17 & 0.24 & 0.24 \\
\hline & $10-11$ & 32.75 & 27.59 & 41.24 & 0.29 & 0.21 & 0.28 \\
\hline & $11-12$ & 66.61 & 14.41 & 18.82 & 0.79 & 0.17 & 0.22 \\
\hline & $0-18.1$ & 52.28 & 20.25 & 21.69 & 1.21 & 0.43 & 0.41 \\
\hline \multirow[t]{8}{*}{847} & $0-1$ & 68.35 & 17.82 & 13.30 & 1.46 & 0.35 & 0.26 \\
\hline & $3-4$ & 67.89 & 12.28 & 18.82 & 1.15 & 0.2 & 0.32 \\
\hline & $5-6$ & 64.71 & 17.87 & 17.55 & 1.71 & 0.44 & 0.44 \\
\hline & $8-9$ & ND & ND & ND & ND & ND & ND \\
\hline & $9-10$ & ND & ND & ND & ND & ND & ND \\
\hline & $10-11$ & ND & ND & ND & ND & ND & ND \\
\hline & $11-12$ & ND & ND & ND & ND & ND & ND \\
\hline & $0-6.7$ & 61.94 & 21.1 & 16.95 & 1.33 & 0.41 & 0.33 \\
\hline \multirow[t]{8}{*}{848} & $0-1$ & 75.52 & 11.18 & 12.61 & 0.84 & 0.11 & 0.13 \\
\hline & $3-4$ & 54.43 & 15.20 & 29.13 & 0.10 & 0.03 & 0.06 \\
\hline & $5-6$ & 71.49 & 14.38 & 12.84 & 0.75 & 0.15 & 0.13 \\
\hline & $8-9$ & 78.42 & 5.80 & 15.75 & 0.32 & 0.02 & 0.07 \\
\hline & $9-10$ & 51.02 & 12.28 & 28.64 & 0.22 & 0.04 & 0.08 \\
\hline & $10-11$ & 69.82 & 3.32 & 18.94 & 0.31 & 0.01 & 0.08 \\
\hline & $11-12$ & 86.65 & 2.30 & 11.20 & 0.46 & 0.01 & 0.06 \\
\hline & $0-11.4$ & 70.02 & 11.72 & 15.44 & 0.49 & 0.08 & 0.10 \\
\hline \multirow[t]{8}{*}{849} & $0-1$ & 80.49 & 8.87 & 9.85 & 1.90 & 0.20 & 0.22 \\
\hline & $3-4$ & 74.89 & 11.46 & 12.98 & 1.62 & 0.24 & 0.26 \\
\hline & $5-6$ & 75.36 & 13.81 & 10.76 & 4.53 & 0.84 & 0.64 \\
\hline & $8-9$ & 76.07 & 9.75 & 13.29 & 1.67 & 0.18 & 0.21 \\
\hline & $9-10$ & 42.53 & 25.36 & 34.08 & 0.44 & 0.21 & 0.28 \\
\hline & $10-11$ & 56.11 & 22.39 & 21.74 & 0.81 & 0.32 & 0.29 \\
\hline & $11-12$ & 75.30 & 9.38 & 13.44 & 1.36 & 0.17 & 0.25 \\
\hline & $0-11.6$ & 71.13 & 14.16 & 12.91 & 2.50 & 0.55 & 0.41 \\
\hline 850 & $0-1$ & 77.19 & 10.87 & 12.36 & 1.17 & 0.16 & 0.19 \\
\hline & $3-4$ & 69.63 & 11.77 & 17.26 & 1.11 & 0.18 & 0.26 \\
\hline & $5-6$ & 69.89 & 17.34 & 12.28 & 3.79 & 0.86 & 0.60 \\
\hline & $8-9$ & 73.03 & 14.10 & 11.96 & 2.17 & 0.38 & 0.34 \\
\hline & $9-10$ & 57.20 & 25.18 & 18.18 & 1.08 & 0.44 & 0.32 \\
\hline & $10-11$ & 49.95 & 32.55 & 17.38 & 1.49 & 0.83 & 0.41 \\
\hline & $11-12$ & 72.29 & 15.17 & 12.69 & 1.94 & 0.4 & 0.33 \\
\hline & $0-12.0$ & 68.56 & 17.59 & 13.66 & 2.31 & 0.61 & 0.44 \\
\hline 851 & $0-1$ & 82.01 & 5.90 & 10.24 & 1.23 & 0.08 & 0.14 \\
\hline & $3-4$ & 74.09 & 8.27 & 16.98 & 0.91 & 0.1 & 0.20 \\
\hline & $5-6$ & 75.46 & 11.39 & 11.90 & 2.23 & 0.35 & 0.35 \\
\hline & $8-9$ & 72.86 & 12.23 & 13.81 & 1.97 & 0.33 & 0.36 \\
\hline & $9-10$ & 57.10 & 15.69 & 21.06 & 1.17 & 0.32 & 0.43 \\
\hline & $10-11$ & 55.47 & 14.15 & 19.01 & 1.54 & 0.38 & 0.52 \\
\hline & $11-12$ & 73.29 & 10.57 & 16.24 & 1.74 & 0.24 & 0.36 \\
\hline & $0-12.6$ & 72.21 & 11.58 & 14.20 & 1.79 & 0.33 & 0.36 \\
\hline 852 & $0-1$ & 73.76 & 4.65 & 18.79 & 0.59 & 0.03 & 0.14 \\
\hline & $3-4$ & 63.69 & 6.19 & 29.81 & 0.35 & 0.03 & 0.14 \\
\hline & $5-6$ & 78.10 & 4.88 & 17.07 & 0.92 & 0.05 & 0.18 \\
\hline & $8-9$ & 82.69 & 4.32 & 10.81 & 0.91 & 0.04 & 0.09 \\
\hline & $9-10$ & 54.87 & 11.89 & 31.93 & 0.18 & 0.03 & 0.09 \\
\hline & $10-11$ & 68.43 & 7.90 & 26.10 & 0.35 & 0.04 & 0.13 \\
\hline & $11-12$ & ND & ND & ND & ND & ND & ND \\
\hline & $0-11.4$ & 75.65 & 5.17 & 18.94 & 0.71 & 0.04 & 0.14 \\
\hline 853 & $0-1$ & 70.24 & 3.84 & 25.47 & 0.16 & 0.01 & 0.05 \\
\hline & $3-4$ & 59.57 & 2.39 & 38.46 & 0.20 & 0.01 & 0.12 \\
\hline & $5-6$ & 73.99 & 1.46 & 23.45 & 0.52 & 0.01 & 0.16 \\
\hline & $8-9$ & 81.48 & 1.1 & 17.42 & 0.86 & 0.01 & 0.17 \\
\hline & $9-10$ & ND & ND & ND & ND & ND & ND \\
\hline & $10-11$ & ND & ND & ND & ND & ND & ND \\
\hline
\end{tabular}


Table 4 (continued).

\begin{tabular}{cccccccc}
\hline Site & $\begin{array}{c}\text { Interval } \\
(\mathrm{Ma})\end{array}$ & $\begin{array}{c}\mathrm{CaCO}_{3} \\
(\%)\end{array}$ & $\begin{array}{c}\text { Opal } \\
(\%)\end{array}$ & $\begin{array}{c}\text { Terrigenous } \\
(\%)\end{array}$ & $\begin{array}{c}\mathrm{CaCO}_{3} \\
\mathrm{MAR} \\
\left(\mathrm{g} / \mathrm{cm}^{2} / \mathrm{k} . \mathrm{y} .\right)\end{array}$ & $\begin{array}{c}\text { Opal } \\
\text { MAR } \\
\left(\mathrm{g} / \mathrm{cm}^{2} / \mathrm{k} . \mathrm{y} .\right)\end{array}$ & $\begin{array}{c}\text { Terrigenous } \\
\text { MAR } \\
\left(\mathrm{g} / \mathrm{cm}^{2} / \mathrm{k} . \mathrm{y} .\right)\end{array}$ \\
\hline \multirow{4}{*}{854} & $11-12$ & $\mathrm{ND}$ & $\mathrm{ND}$ & $\mathrm{ND}$ & $\mathrm{ND}$ & $\mathrm{ND}$ & $\mathrm{ND}$ \\
& $0-8.9$ & 72.83 & 1.81 & 24.00 & 0.48 & 0.01 & 0.14 \\
& $0-1$ & 36.44 & 7.98 & 47.54 & 0.08 & 0.02 & 0.10 \\
& $3-4$ & 42.47 & 5.57 & 51.96 & 0.02 & 0.00 & 0.02 \\
& $5-6$ & Hiatus & Hiatus & Hiatus & Hiatus & Hiatus & Hiatus \\
& $8-9$ & 8.51 & 7.64 & 84.70 & 0.03 & 0.01 & 0.13 \\
& $9-10$ & 0.18 & 3.54 & 96.25 & 0.00 & 0.01 & 0.16 \\
& $10-11$ & ND & ND & ND & ND & ND & ND \\
& $11-12$ & ND & ND & ND & ND & ND & ND \\
& $0-9.9$ & 23.47 & 8.13 & 68.23 & 0.07 & 0.02 & 0.18 \\
\hline
\end{tabular}

Note: $\mathrm{ND}=$ No data.

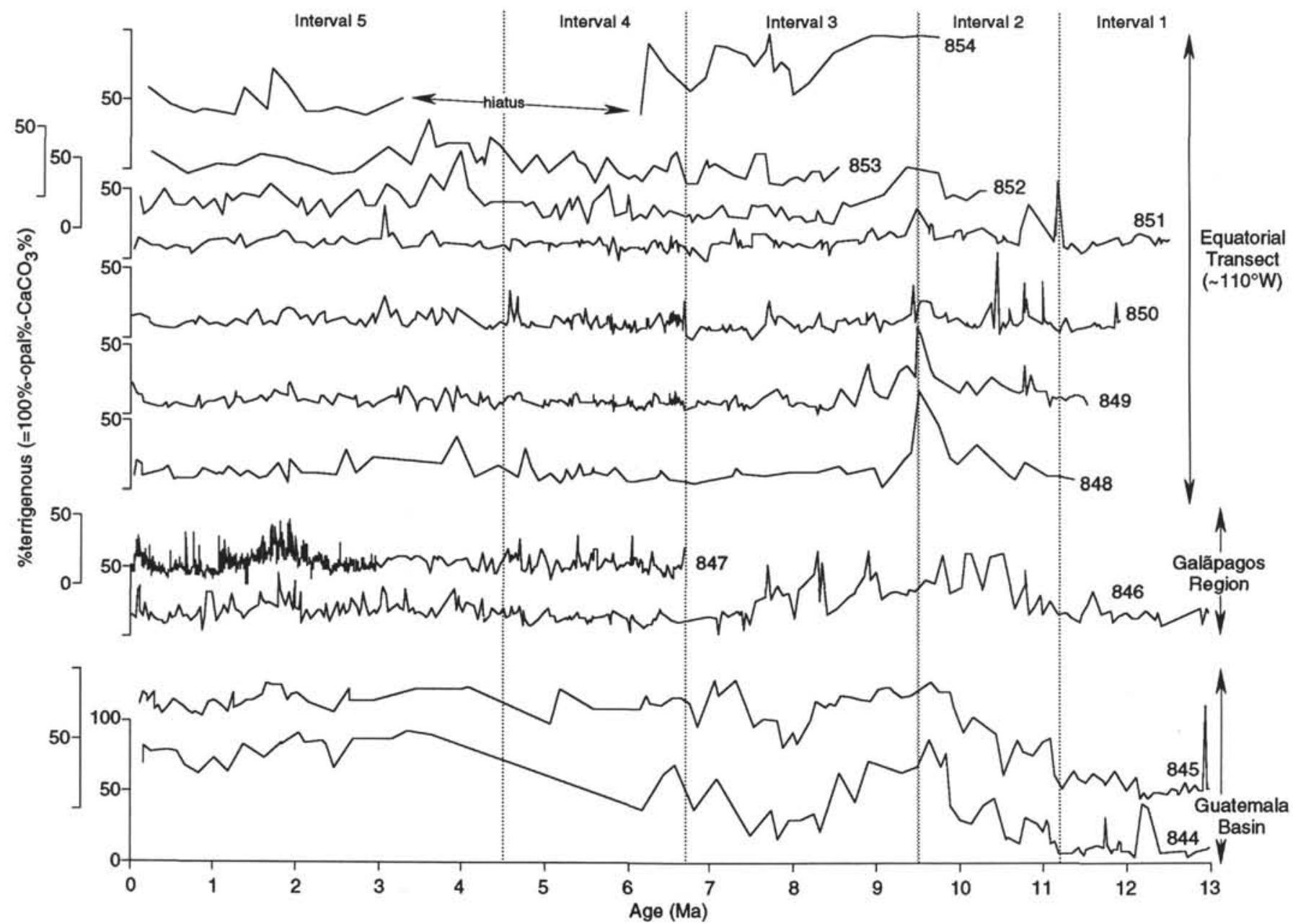

Figure 11. Estimated \%terrigenous material in bulk sediments vs. age in the Leg 138 sites.

Only Sites 850 and 851 maintained mean $\mathrm{CaCO}_{3}$ MARs above 1 $\mathrm{g} / \mathrm{cm}^{2} / \mathrm{k}$.y., whereas four sites had levels above $2 \mathrm{~g} / \mathrm{cm}^{2} / \mathrm{k}$.y. at 5 to 6 Ma. Highest $\mathrm{CaCO}_{3}$ concentrations and MARs occurred near the equator, as in other times.

The "carbonate crash" was not accompanied by a similar collapse of opal sedimentation. In fact, opal percentages and MARs at this time were not significantly different from the long-term average (Fig. 23). Values in the 9- to 10-Ma interval were similar to those observed in the middle Miocene (11-12 Ma) and were slightly higher than those in middle Pliocene (3-4 Ma). Compared to Leinen's (1979) opal MAR map for the 7- to 10-Ma interval, our MARs are at least $50 \%$ lower for the equatorial region near $105^{\circ} \mathrm{W}$. Some of this difference can undoubtedly be attributed to contrasts in backtracks, age models, and different time interval binning. The absence of a complementary opal crash argues against a change in surface-water productivity (i.e., changes in nutrient influx, temperature, etc.) that would affect both the carbonate and opal producers.

\section{$10-11 \mathrm{Ma}$}

The $10-11 \mathrm{Ma}$ interval immediately preceded the "carbonate crash" (Fig. 21). This interval is characterized by its variability in 


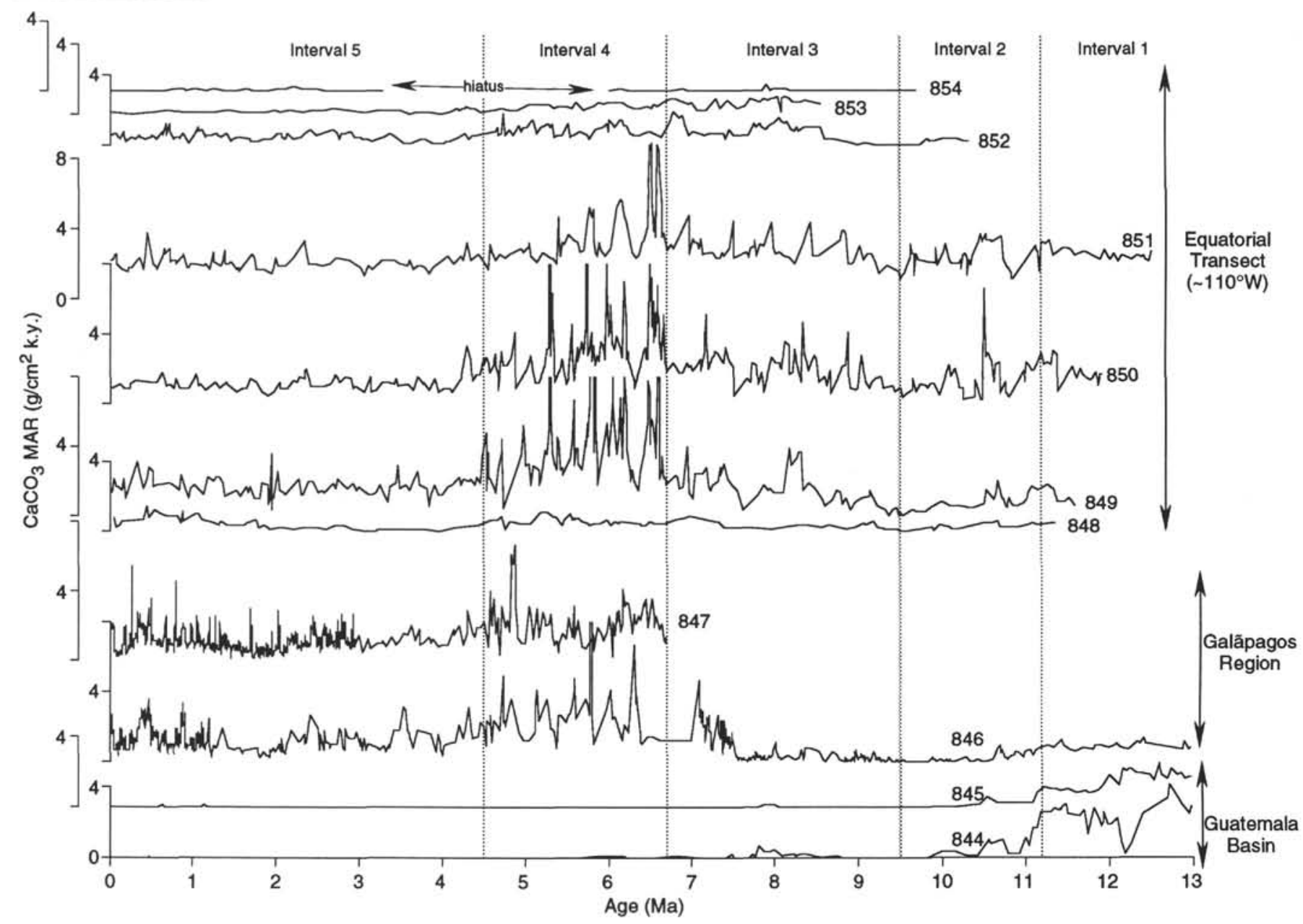

Figure 12. $\mathrm{CaCO}_{3}$ MAR vs. age in the Leg 138 sites.

biogenic accumulation and, particularly, concentration, which is better seen by comparing time series (Figs. 9-14). This time interval witnessed the widespread presence of diatom mats at various sites in the equatorial Pacific (Kemp and Baldauf, 1993), including Sites 844, 850 , and 851 . The second highest mean opal MAR of any site or time interval was recorded at Site 850 at this time, and it probably reflects the occurrence of diatom deposits (Kemp and Baldauf, 1993).

\section{1-12 Ma}

The 11-12 Ma time interval is interesting because the $\mathrm{CaCO}_{3}$ MARs at Sites 844 and 845 were as much as three times higher than those at Site 846, even though Site 845 was farther from the equator (Fig. 22). This results in a spatial pattern that shows a weak northeast-southwest gradient. This pattern was also observed in the opal MAR distribution.

\section{SYNOPSIS OF HIGHLIGHTS}

Three major highlights that emerged from the evolving pattern of EEP sedimentation since 13 Ma were (1) the "carbonate crash" in the middle late Miocene (centered at $9.5 \mathrm{Ma}$ ); (2) the "biogenic bloom," which lasted from the late Miocene to the early Pliocene (6.7-4.5 $\mathrm{Ma}$ ); and (3) a shift in locus of maximum opal accumulation at $4.4 \mathrm{Ma}$ that coincided with the final closure of the Panamanian seaway. Here, we examine these events with a broader paleoceanographic and geologic perspective, and we speculate about their causes and effects.

\section{"Carbonate Crash"}

The $\mathrm{CaCO}_{3}$ dissolution event centered at $9.5 \mathrm{Ma}$ had previously been described (van Andel et al., 1975; Vincent, 1981; and Theyer et al., 1985), but the results from Leg 138 enable us to examine this event in significantly greater detail. Vincent (1981) first identified this event, on the basis of low $\% \mathrm{CaCO}_{3}$ values, in records from the Panama Basin (Site 158) and the Hess Rise (Site 310) (north central Pacific). She named the event "Mid Epoch 10" because of its location within the paleomagnetic stratigraphy. Mayer et al. (1986) correlated this event, as identified in sedimentary records from Leg 85 , to seismic reflector "IM-P," which they associated with hiatus "NH4" (Barron et al., 1985a). In a continuation of this effort, Bloomer et al. (this volume) correlate IM-P to reflector "R8-b," which was observed throughout the Leg 138 sites. Correlation of the sedimentary and seismic records has led to the mapping of this dissolution event over a large portion of the equatorial Pacific. Here, we (1) reconstruct the chronology of the carbonate crash, as expressed in the various EEP basins; (2) demonstrate that the crash extended far beyond the EEP; and (3) speculate about the origin of the crash.

\section{Chronology of the Carbonate Crash}

The decrease in $\mathrm{CaCO}_{3}$ percentages and MARs observed in the Guatemala Basin (Sites 844 and 845 ) between 12 and 12.5 Ma (Fig. 15) may be considered the initiation of the carbonate crash, or a precursory event. Increased carbonate dissolution from 12 to $12.5 \mathrm{Ma}$ 


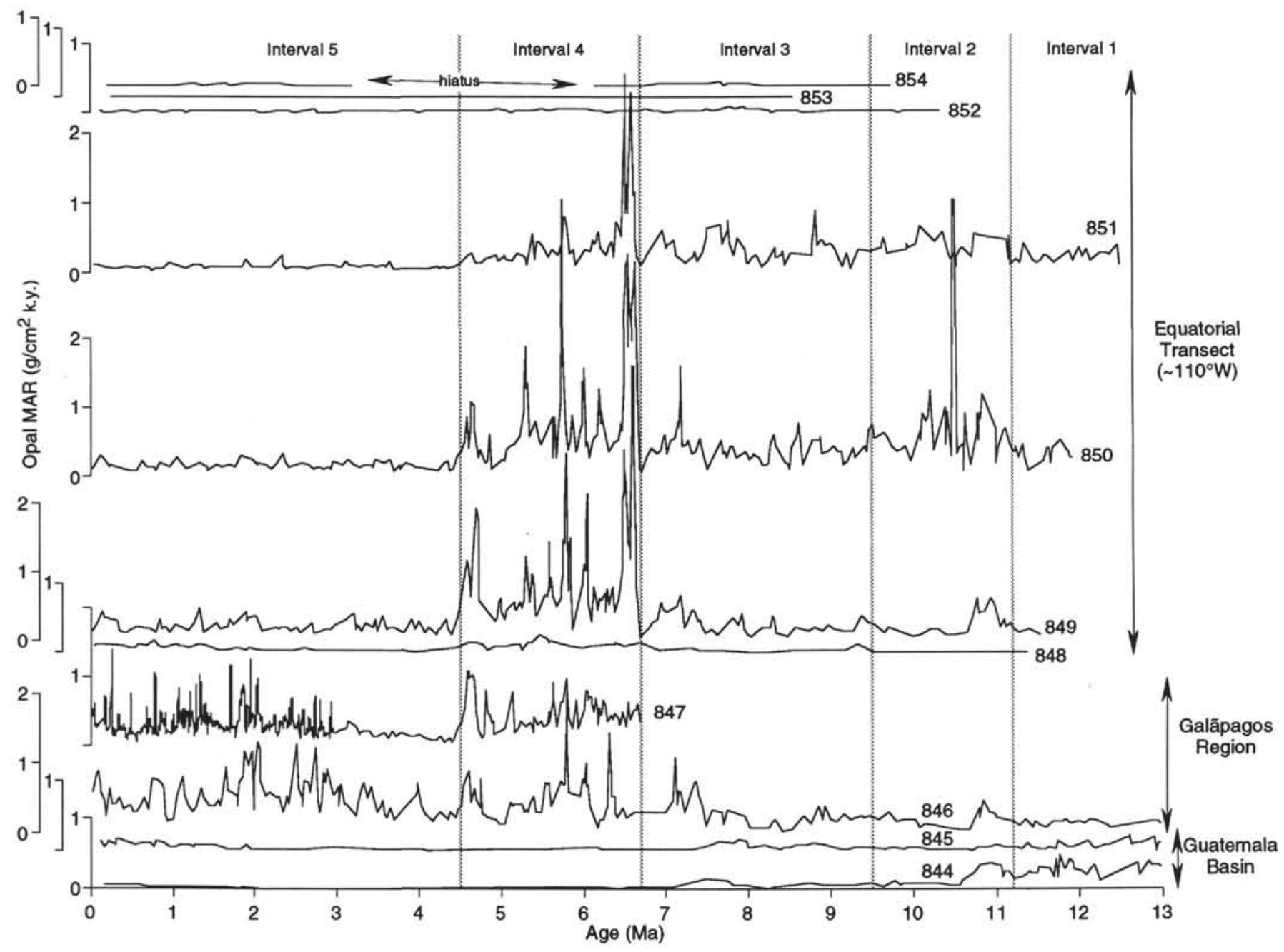

Figure 13. Opal MAR vs. age in the Leg 138 sites.

is also indicated by declines in nannofossil preservation observed at Sites 844, 846, and 851 (Fig. 5). This initial decrease in $\mathrm{CaCO}_{3}$ preservation was followed by a brief increase in preservation, and then by a major decrease in carbonate sedimentation beginning at about 11.2 $\mathrm{Ma}$. This decline in $\mathrm{CaCO}_{3}$, which may be interpreted as the genuine initiation of the crash, was observed at all sites, but was particularly severe in the Guatemala Basin (Fig. 15). $\mathrm{CaCO}_{3}$ percentages and MARs decreased in a series of steps from 11.2 to $9.5 \mathrm{Ma}$, which is more clearly observed at the sites having higher sedimentation rates (e.g., Site 846). Correlatable $\% \mathrm{CaCO}_{3}$ and $\mathrm{CaCO}_{3} \mathrm{MAR}$ minima in this transitional interval can be observed at about 10.9 (Event 9), 10.3 (Event 7), and 9.5 Ma (Event 5) (Figs. 24 and 25). The \% $\mathrm{CaCO}_{3}$ minima in this transition are \%opal maxima because of greater opal production and/or concentration of the opal by $\mathrm{CaCO}_{3}$ dissolution. Increases in opal MARs also occurred at 10.9 and $10.3 \mathrm{Ma}$, when $\mathrm{CaCO}_{3} \mathrm{MARs}$ declined (Fig. 12). Taken together, these observations support the contention that influx of opal was greater at these times, particularly at Site 850 . The fluctuations between dominance by $\mathrm{CaCO}_{3} \mathrm{MAR}$ vs. opal MAR, from 11.2 to $9.5 \mathrm{Ma}$, suggest changes in the abyssal water chemistry as well as the surface ocean ecosystem.

The interval at $9.5 \mathrm{Ma}$ in the Leg 138 sites was the nadir of the crash and is characterized by what was possibly the strongest dissolution of the entire late Neogene, as inferred from the extremely low $\mathrm{CaCO}_{3}$ percentages and MARs and from the poor nannofossil preservation. This interval, here dubbed Event 5 (Figs. 24 and 25), has been correlated to the characteristic "Mid Epoch 10" event (Vincent, 1981) in Site 158, which was also called Event 10e by Barron et al. (1985a). For a brief period, near $9.5 \mathrm{Ma}, \mathrm{CaCO}_{3} \mathrm{MAR}$ essentially ceased at most of the sites, including many in the Pacific Basin. From 9.6 to 9.4 $\mathrm{Ma}$, only Sites 850 and 851 maintained mean $\mathrm{CaCO}_{3}$ MAR levels above $0.2 \mathrm{~g} / \mathrm{cm}^{2} / \mathrm{k}$.y. This suggests that the CCD shoaled above the most of the Leg 138 sites, which were at paleodepths of less than $\sim 3400 \mathrm{~m}$ at $9.5 \mathrm{Ma}$ (except for Site 845 , which was at $3500 \mathrm{~m}$ ) (Lyle et al., this volume). This shoaling, though short-lived, raised the CCD by more than $1400 \mathrm{~m}$ relative to the long-term average of $4800 \mathrm{~m}$ for the equatorial Pacific (van Andel et al., 1975). Although this change in CCD appears to have been unusually rapid and large, similar CCD movements have been observed in the northeast Pacific during the late Quaternary (Karlin et al., 1992).

Recovery from the carbonate crash began by about $9.4 \mathrm{Ma}$ and continued to $9.2 \mathrm{Ma}$, before the onset of another dissolution event (Event 3, which was subdivided into $3 \mathrm{a}$ and $3 \mathrm{~b}$ in the more highly resolved records; Figs. 24 and 25). After Event 3, centered at about $8.9 \mathrm{Ma}, \% \mathrm{CaCO}_{3}$ and $\mathrm{CaCO}_{3} \mathrm{MARs}$ continued to rise and reached a peak (Event 2) between 8.5 and $8.0 \mathrm{Ma}$. After that, another carbonate decline occurred, centered at $\sim 7.9 \mathrm{Ma}$. This was followed by a rise at $7.5 \mathrm{Ma}$, which was especially distinct in the $\mathrm{CaCO}_{3}$ MARs at Sites 846 and 850 (Figs. 15 and 25). This rise is considered the end of the crash, except in the Guatemala Basin (Sites 844 and 845). There, $\mathrm{CaCO}_{3}$ MAR increased slightly after $8.9 \mathrm{Ma}$, but the recovery was 


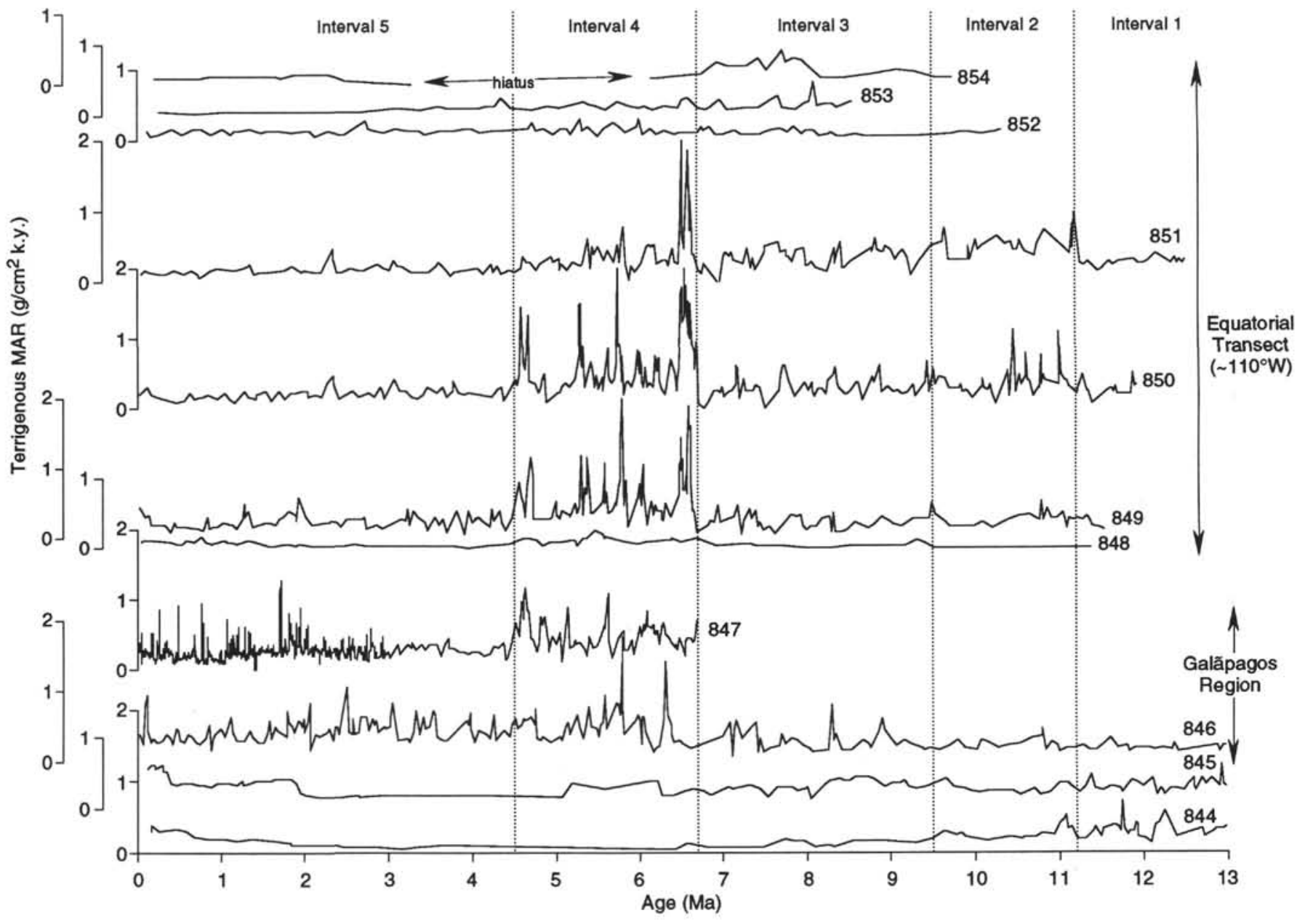

Figure 14. Terrigenous MAR vs. age in the Leg 138 sites.

short-lived (Fig. 15). Carbonate accumulation declined and essentially had ceased by $7.5 \mathrm{Ma}$. The Guatemala Basin sites have remained near, or below, the regional CCD ever since.

\section{Spatial Extent of the Carbonate Crash}

Stratigraphic correlation demonstrates that the carbonate crash extended well beyond the EEP. Here, we show that sedimentary records from the CEP clearly indicate the event. The crash is also evident in records from the WEP and the north central Pacific, though correlation into the latter region is less certain.

Identification of the carbonate crash in the CEP was accomplished by correlating the Leg 138 records with those from RC12-65 (Saito et al., 1975), RC12-66 (Saito et al., 1975), and Site 574 (Weinreich and Theyer, 1985; Pisias et al., 1985; Farrell, 1991; Fig. 24). The original age models for these $\% \mathrm{CaCO}_{3}$ records were based on the paleomagnetic stratigraphies (Foster and Opdyke, 1970; Weinreich and Theyer, 1985). These age models have been updated (e.g., Dunn and Moore, 1981; Barron et al., 1985a; Farrell and Prell, 1991; this study) and are now compatible with the Leg 138 time scale. The CEP $\% \mathrm{CaCO}_{3}$ records were converted to MAR records (Fig. 25) by using the sedimentation rates from these age models and estimates of dry bulk density (DBD in $\mathrm{g} / \mathrm{cm}^{3}$ ) based on this equation from Farrell (1991),

$$
\begin{gathered}
\mathrm{DBD}=0.32003+1.1114 \mathrm{E}-3\left(\% \mathrm{CaCO}_{3}\right)-5.4727 \mathrm{E}-6\left(\% \mathrm{CaCO}_{3}\right)^{2} \\
+7.5043 \mathrm{E}-7\left(\% \mathrm{CaCO}_{3}\right)^{3} .
\end{gathered}
$$

The events observed in the EEP are clearly recognized in the CEP, as demonstrated by the correlation of $\mathrm{CaCO}_{3}$ Events 0 to 11 into Site
574 (Figs. 24 and 25). The transition into the carbonate crash at Site 574 was observed to be between 11.2 and $9.5 \mathrm{Ma}$, and at the dissolution maximum, the $\% \mathrm{CaCO}_{3}$ values are less than $10 \%$ (Pisias et al., 1985). Recovery from the crash (9.4-7.5 Ma) was observed at Sites 574 and $\mathrm{RC} 12-65$. The $\mathrm{CaCO}_{3}$ MAR records from the CEP and the EEP show a strikingly similar pattern during the crash (Fig. 25). In addition, the absolute values of the MARs at Sites 574 and 846 were nearly identical over the interval from 7 to $12 \mathrm{Ma}$, averaging 0.60 and $0.66 \mathrm{~g} / \mathrm{cm}^{2} / \mathrm{k}$.y., respectively, whereas the MARs at Site 850 were approximately three times higher $\left(1.86 \mathrm{~g} / \mathrm{cm}^{2} / \mathrm{k}\right.$.y.; note the scale difference in Fig. 25). The similarity of the MARs at Sites 846 and 574 , despite the shallower depth of Site 846 , may be attributed to lower carbonate influx at Site 846. The latitude of Site 846 was about $3^{\circ} 20^{\prime} \mathrm{S}$ at this time, which may have been south of the high-carbonate productivity zone. The higher MARs at Site 850 are attributed to the shallower depth of the site (compared to Site 574) and to higher carbonate production in the overlying surface waters. The $\mathrm{CaCO}_{3}$ MAR at Core RC12-65 was lower than at other sites, primarily because of the greater water depth of this site, but also because of its northwestern location beneath less productive surface waters. The east-west similarity in the equatorial response of the carbonate system during the carbonate crash changed significantly after 7.5 Ma (Fig. 25 ), when the biogenic bloom began.

Evidence suggests that the carbonate crash extended into the WEP and perhaps even the north central Pacific. We correlated the crash into the WEP through seismic Reflector R3, which was observed at all Leg 130 sites and was assigned an age that ranges between 9.1 and 9.7 Ma on Berggren et al.'s (1985) time scale (Mosher et al., 1993). When converted to the Shackleton et al. (this volume) time scale 


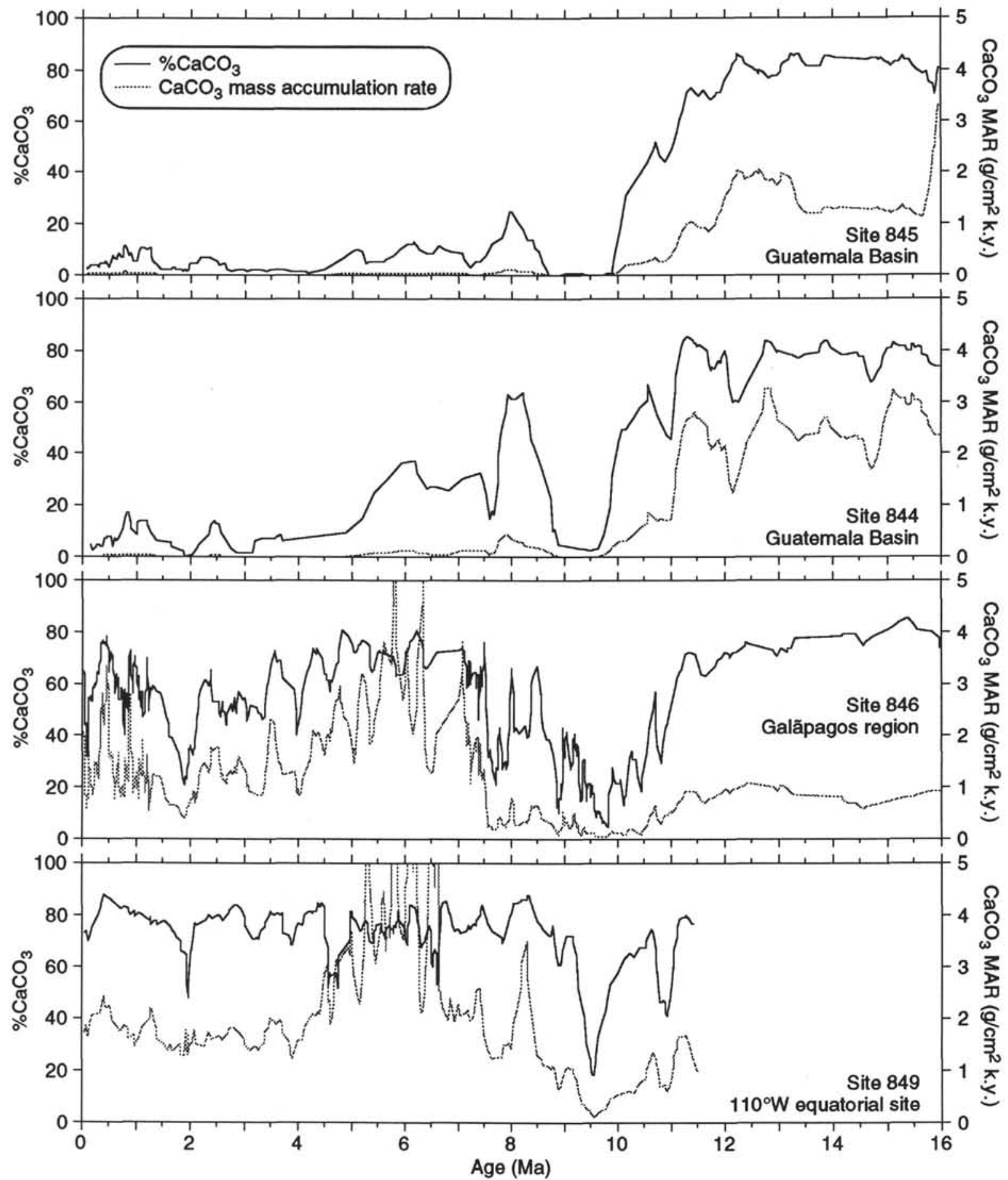

Figure 15. Time series of $\% \mathrm{CaCO}_{3}$ and $\mathrm{CaCO}_{3}$ MAR from Sites $845,844,846$, and 849 highlighting the carbonate crash centered at $9.5 \mathrm{Ma}$. The time series were smoothed with a five-point moving average.

(thus, 9.8 to $10.3 \mathrm{Ma}$ ), this age slightly precedes the nadir of the carbonate crash in the EEP. The lead is probably insignificant, however, given the combined stratigraphic and chronostratigraphic resolutions of the WEP and EEP sites. Mosher et al. (1993) associated Reflector R3 with a strong dissolution event that marked a sharp rise in the lysocline depth and a steepening of the vertical carbonate dissolution gradient. This is consistent with the shoaling of the CCD in the EEP(Lyle et al., this volume). Additional evidence of increased dissolution in the WEP are the extremely low sedimentation rates that occurred near $10 \mathrm{Ma}$ at all five of the Leg 130 sites (Berger et al.,
1993). Berger et al. raised the possibility that these low rates resulted from an artifact in the age models. If subsequent work substantiates the existing age models, then we suggest that the low rates represent increased carbonate dissolution that occurred during the carbonate crash. Finally, identification of the crash in the north central Pacific is based on the identification of the "Mid Epoch 10" event in the $\% \mathrm{CaCO}_{3}$ record from Site 310, on the Hess Rise (Vincent, 1981). This correlation is tenuous, however, given the low resolution of this record, the high probability of gaps in the record, and the relatively minor expression of the event. 

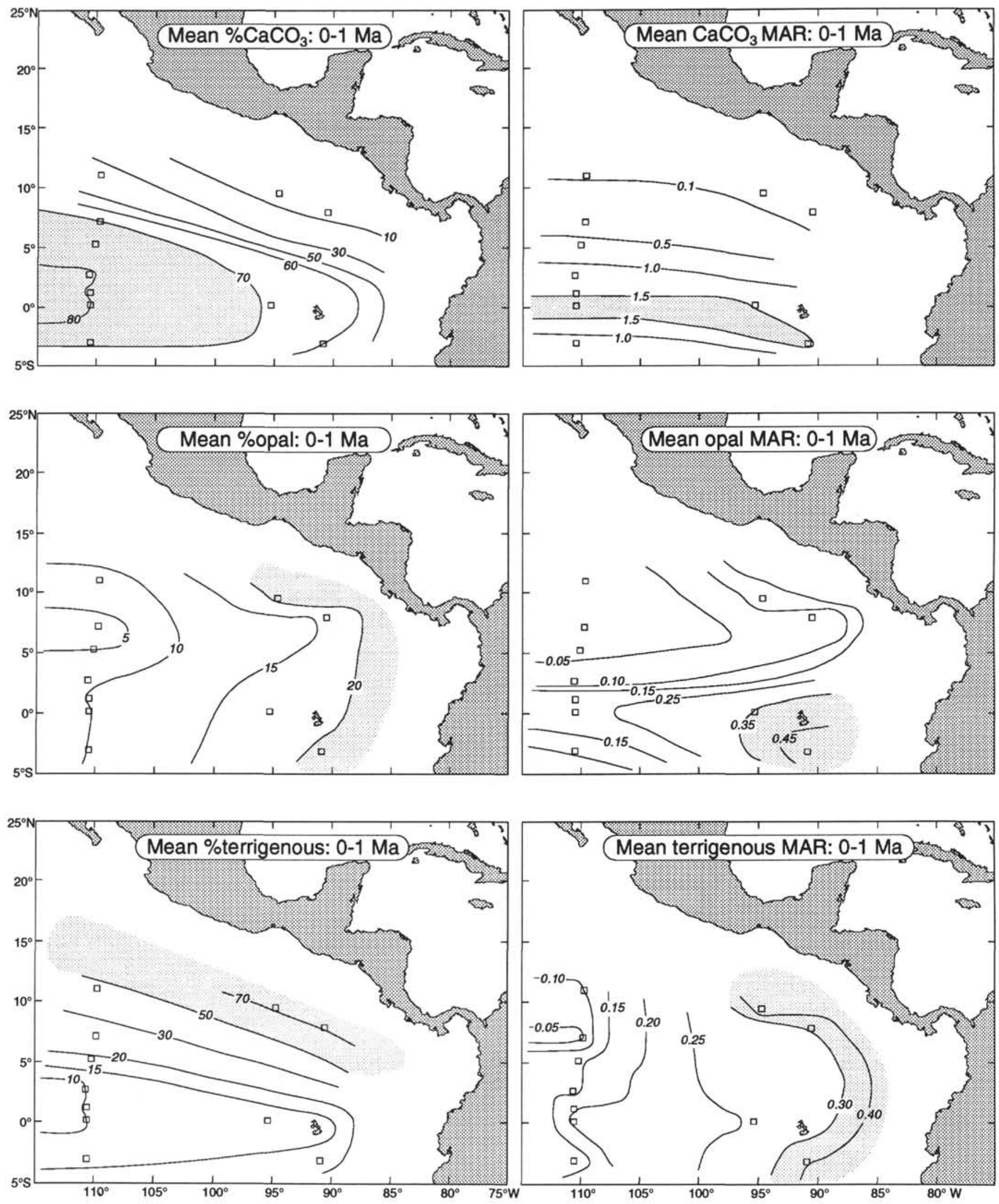

Figure 16. Maps of the mean concentration and $\mathrm{MAR}$ of $\mathrm{CaCO}_{3}$, opal, and terrigenous (estimated) sediments during the 0-1 Ma interval. Isopleths are in weight percent and in $\mathrm{g} / \mathrm{cm}^{2} / \mathrm{k}$.y. Shaded regions in the concentration maps correspond to areas where the sediments contain more than $70 \% \mathrm{CaCO}_{3}, 20 \%$ opal, and $50 \%$ terrigenous, respectively. Shaded regions in the flux maps correspond to areas where accumulation rates exceeded $1.5 \mathrm{~g} / \mathrm{cm}^{2} / \mathrm{k} . \mathrm{y} . \mathrm{CaCO}, 0.35 \mathrm{~g} / \mathrm{cm}^{2} / \mathrm{k} . \mathrm{y} . \mathrm{opal}$, and $0.30 \mathrm{~g} / \mathrm{cm}^{2} / \mathrm{k}$.y. terrigenous sediment, respectively. Drill sites are marked by open squares. 

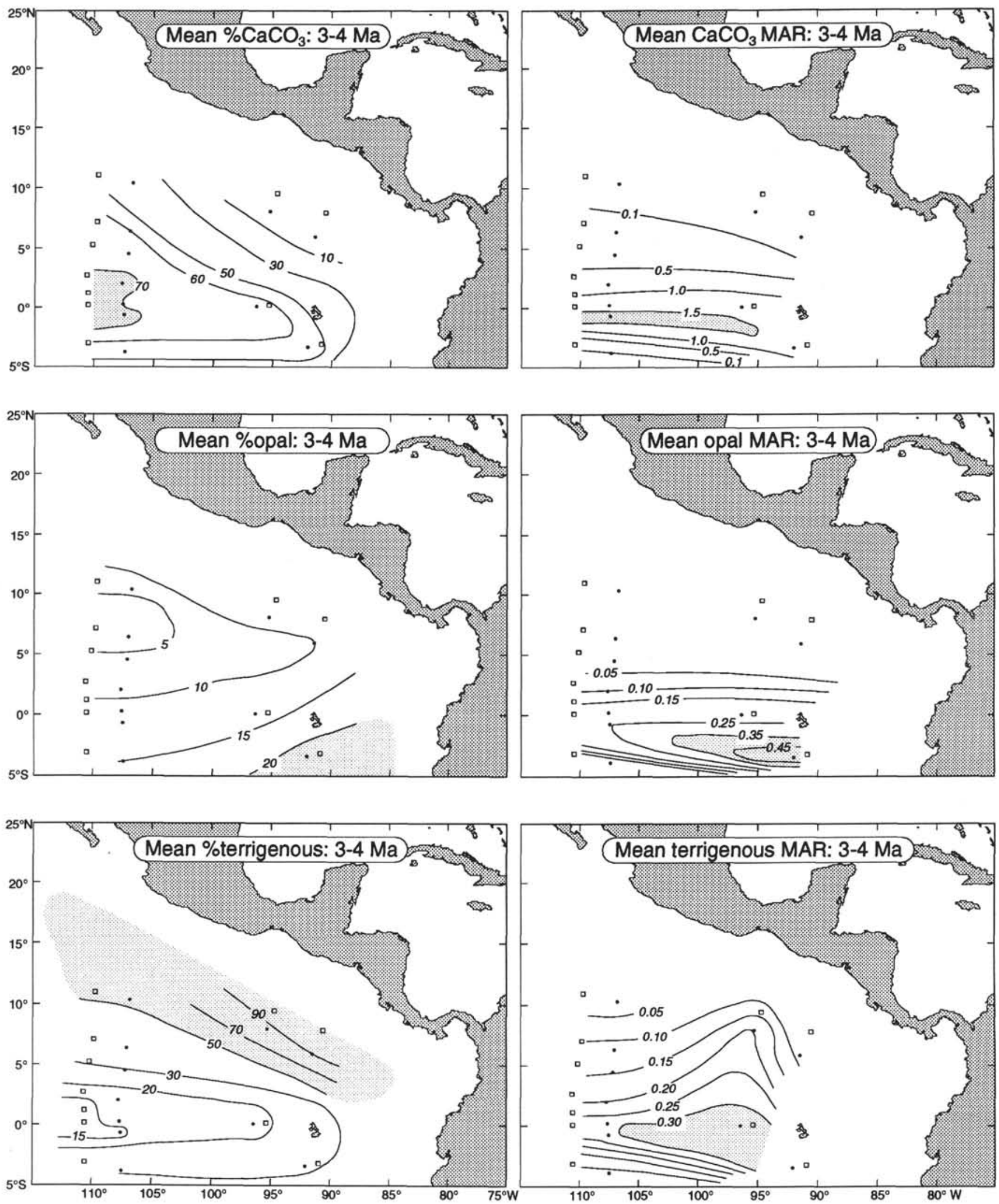

Figure 17. Sedimentation maps for the 3-4 Ma interval. Paleopositions of the sites are marked by solid circles and the modern coastline is shown. Other conventions as in Figure 16. 

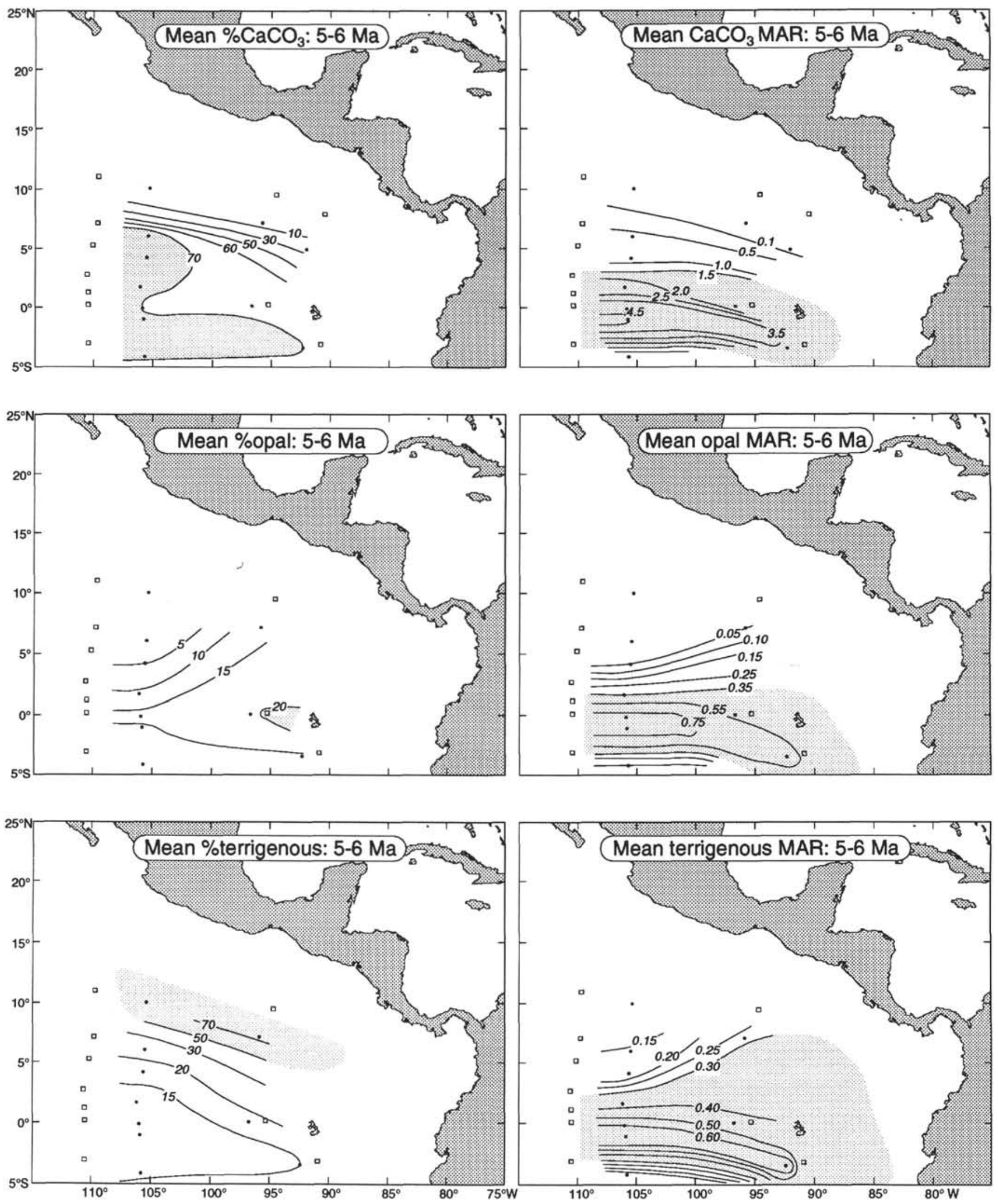

Figure 18. Sedimentation maps for the 5-6 Ma interval, characterized by the biogenic bloom. Sites having no data over this interval (as listed in Table 4) have been removed. For example, the square and circle marking the modern and paleopositions, respectively, for Site 854 , have been deleted because this interval is a hiatus. Other conventions as in Figures 16 and 17. 

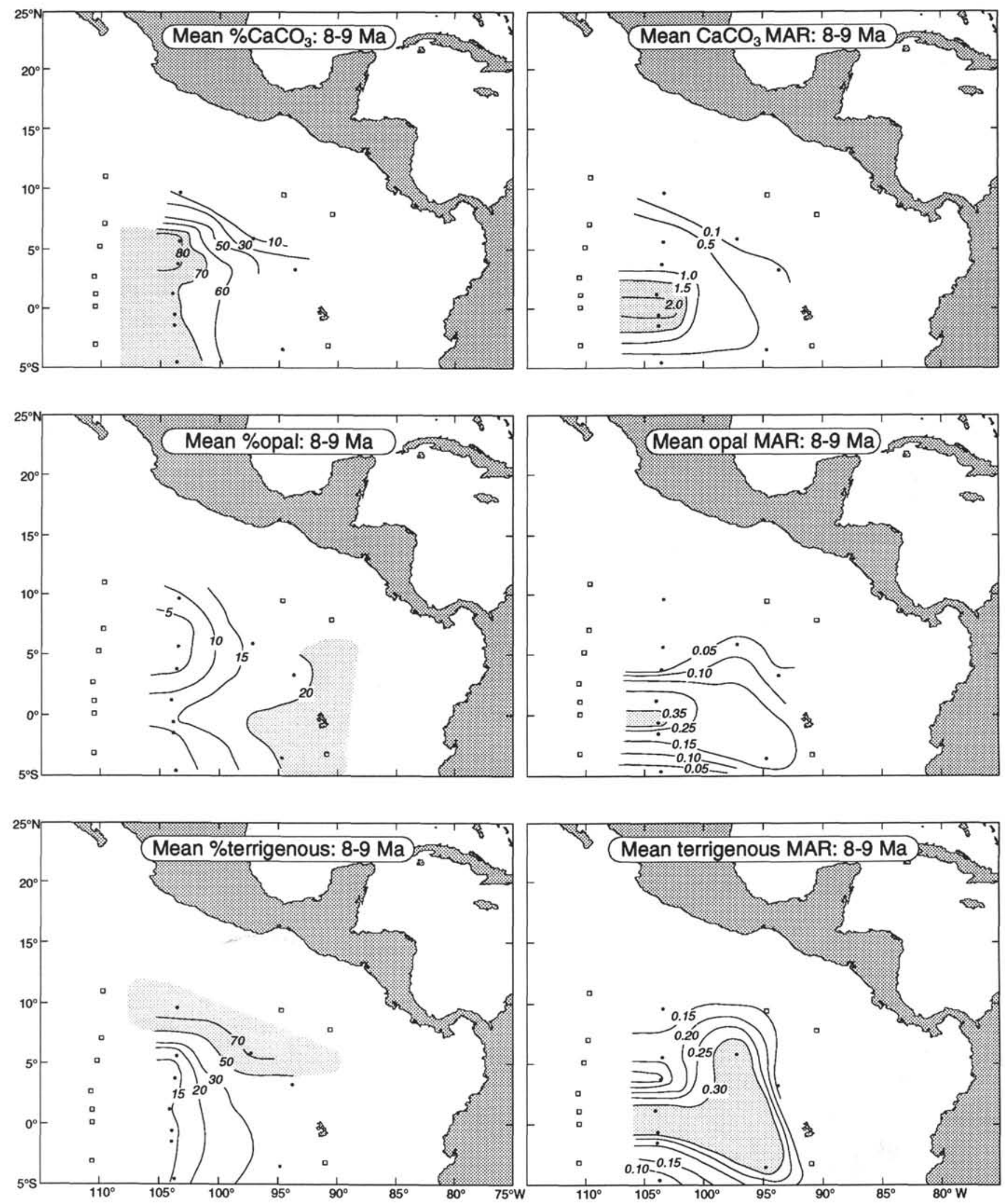

Figure 19. Sedimentation maps for the 8-9 Ma interval. Other conventions as in Figures 16 through 18. 

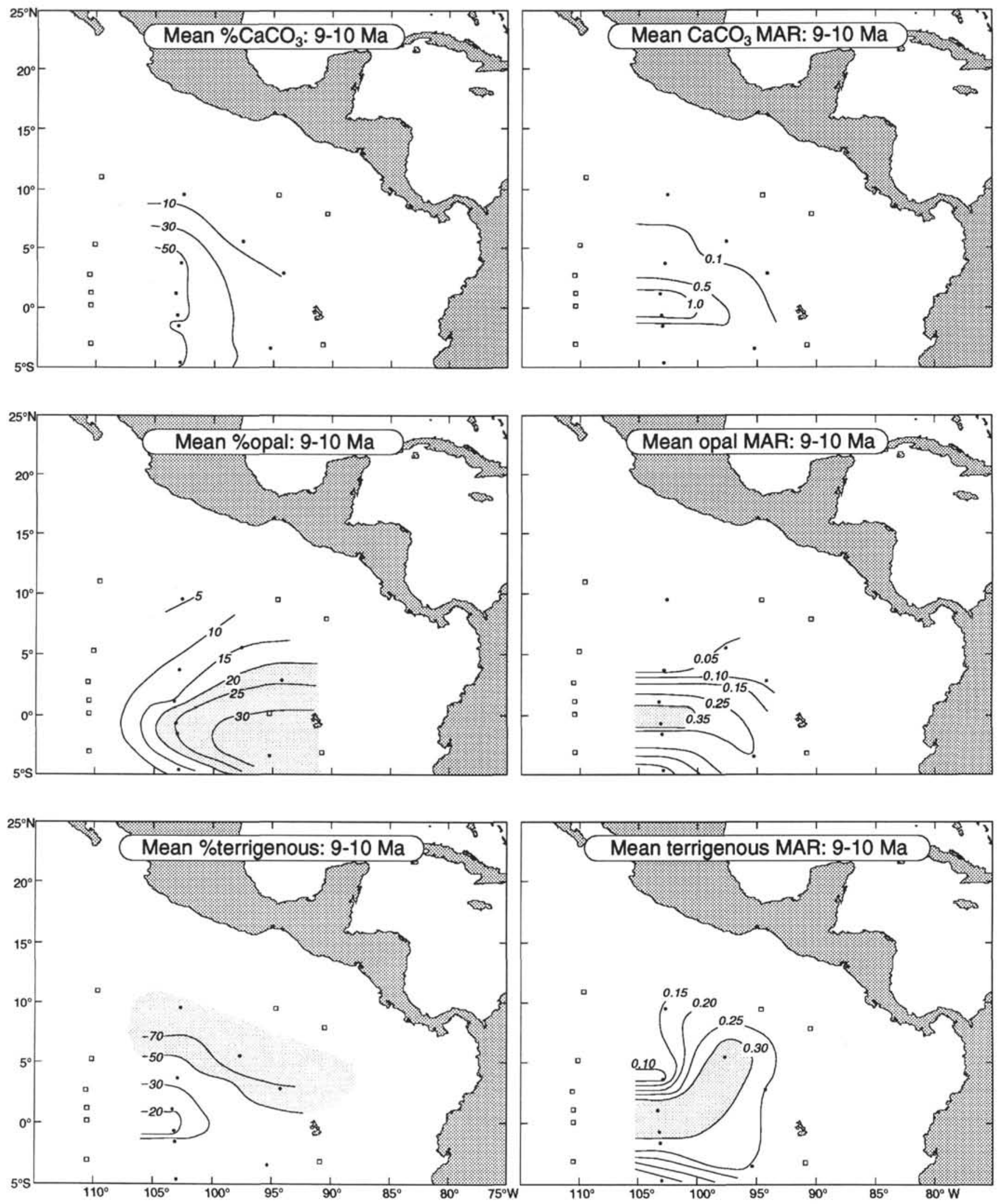

Figure 20. Sedimentation maps for the 9-10 Ma interval, characterized by the carbonate crash. Other conventions as in Figures 16 through 18. 

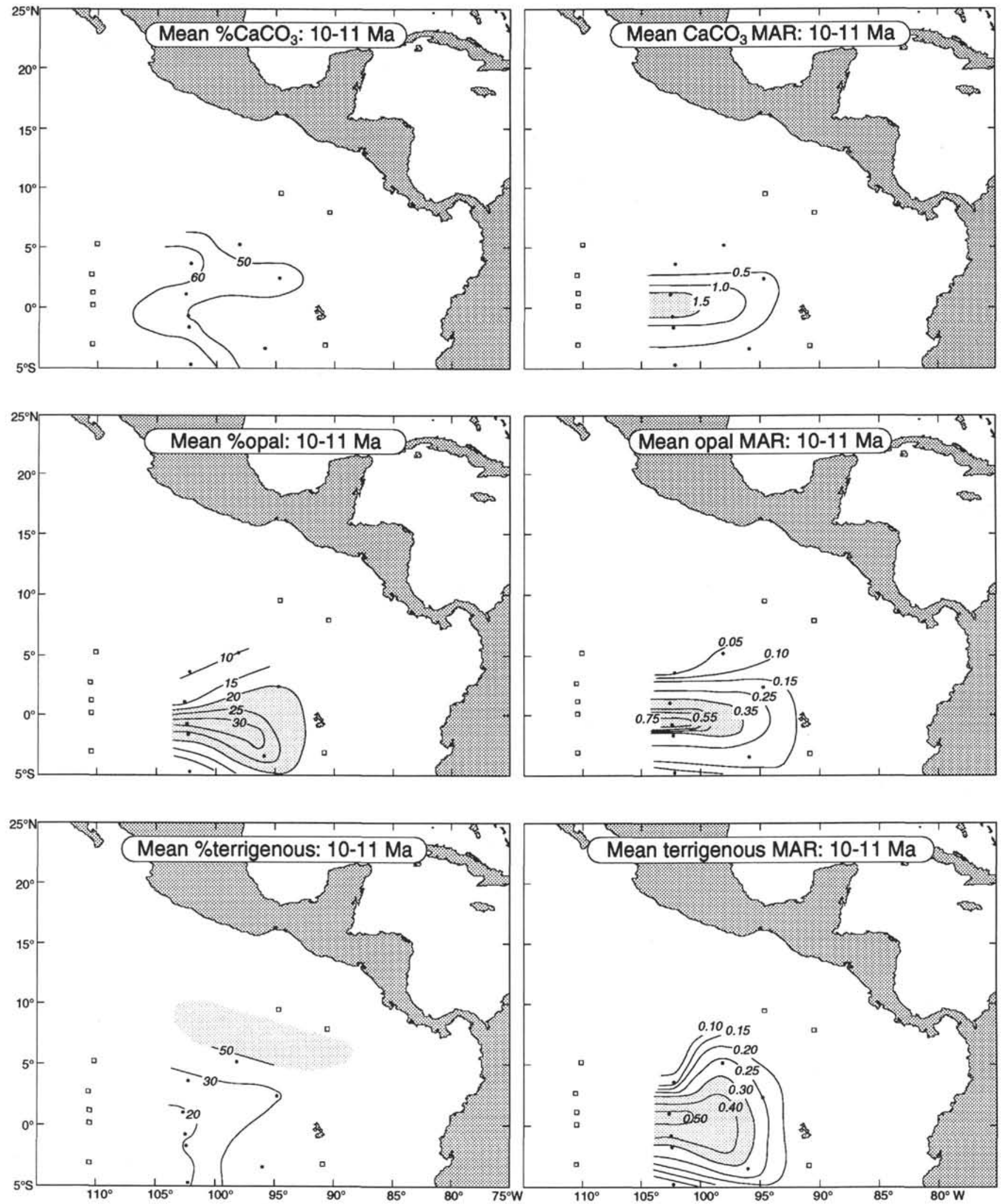

Figure 21. Sedimentation maps for the 10-11 Ma interval. Other conventions as in Figures 16 through 18. 

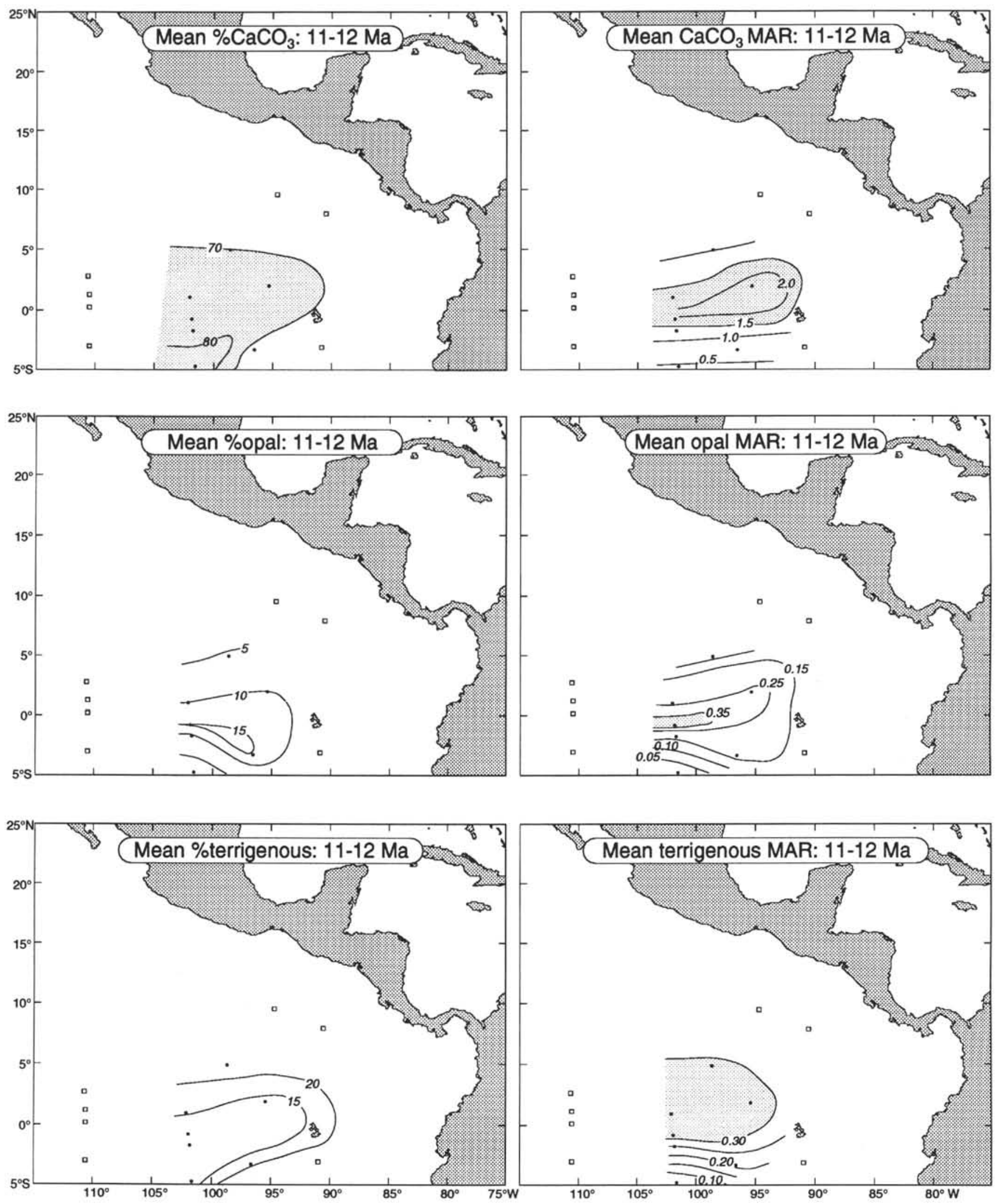

Figure 22. Sedimentation maps for the 11-12 Ma interval. Other conventions as in Figures 16 through 18. 

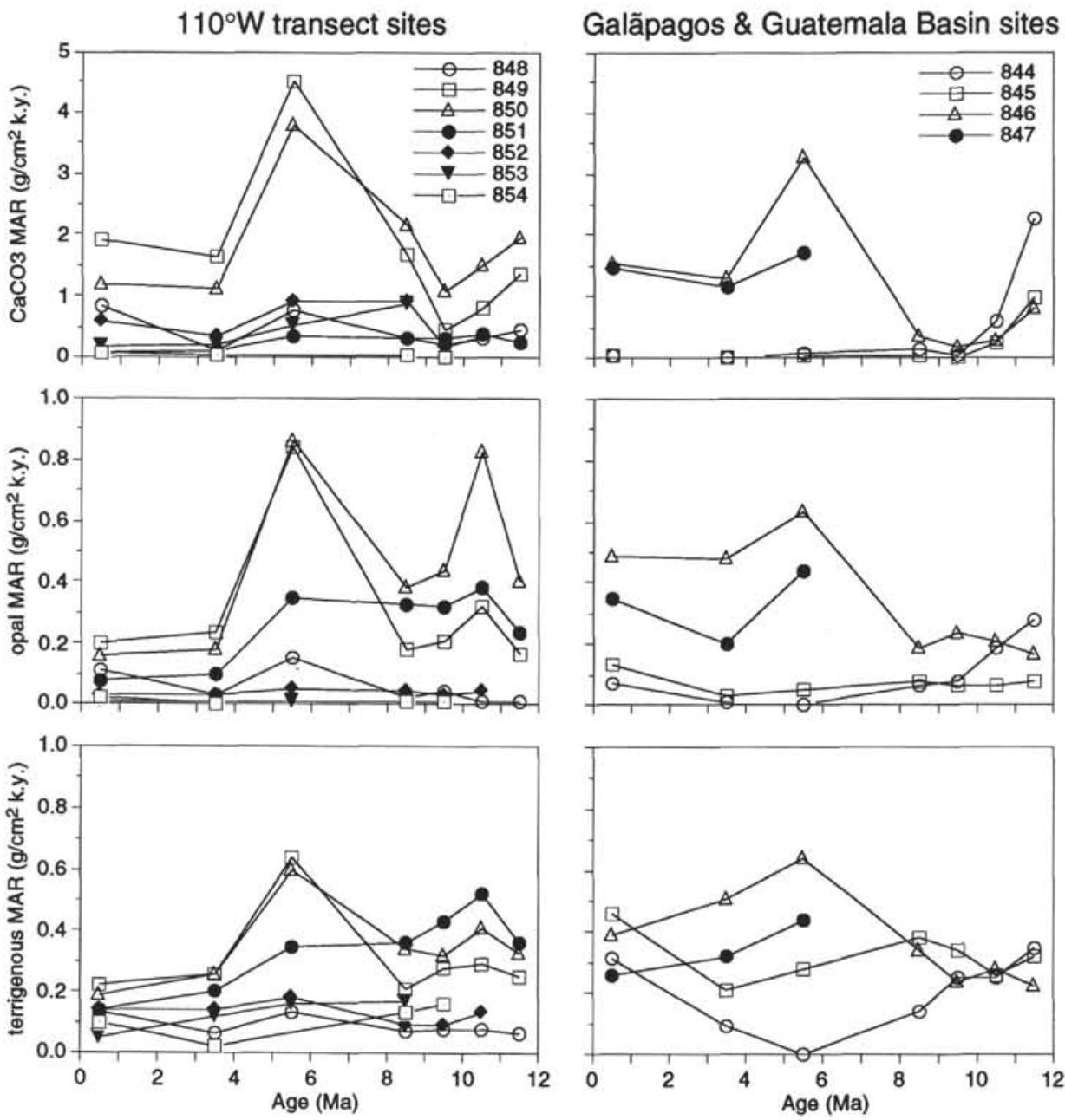

Figure 23. Time series of the mean concentration and mass accumulation rate of $\mathrm{CaCO}_{3}$, opal, and terrigenous (estimated) sediments at the Leg 138 sites during seven selected time intervals (Table 4). The sites have been divided by longitude.

\section{Cause of the Carbonate Crash}

The carbonate crash occurred at about the same time as several major events, including a decline in sea level (Barron et al., 1985b; Haq et al., 1987), reorganization of global deep-water circulation (Wright et al., 1991, 1992), a high productivity event (Theyer et al., 1985), and greater restriction in the Indonesian and Panamanian seaways (Kennett, 1985; Coates et al., 1992). The timing of these events has proven difficult to reconstruct, especially those of the seaway closings. Improved chronologies would help to determine whether any of these events were causatively linked to the carbonate crash. Without the assistance of such chronologies, Lyle et al. (this volume) consider the impact of these events on carbonate sedimentation in the EEP to determine if these might be responsible for causing the carbonate crash. Lyle et al. argue against a change in productivity or sea level as the causative agent, and instead prefer a shift in deepwater chemistry. Two mechanisms capable of causing such a shift have been proposed. The first was a constriction of the Panamanian seaway and, thus, a decrease in the flow of relatively high $\left[\mathrm{CO}_{3}=\right]$ deep water (less corrosive to $\mathrm{CaCO}_{3}$ ) from the Atlantic to the EEP. The second was the onset of North Atlantic Deep Water (NADW) formation and the reorganization of global abyssal circulation.

The Panamanian Seaway mechanism is promising for the following three reasons. First, there appears to be a link between sill depth changes between the Caribbean and the Pacific, as outlined in Table
5 , and $\mathrm{CaCO}_{3}$ events that occurred during the crash. For example, the sill depth was thought to have shoaled between 13 and $12 \mathrm{Ma}$, and then to a shallower depth between 9.9 and $8.7 \mathrm{Ma}$. These shoalings would have restricted the flow of less corrosive deep water into the EEP, resulting in increased dissolution. The first interval corresponds to the precursory dissolution event, just before the initiation of the carbonate crash. The sill shoaling between 9.9 and 8.7 Ma coincides with the time of maximum dissolution, centered at $9.5 \mathrm{Ma}$. Second, as discussed below, ocean modeling efforts (Maier-Reimer et al. 1990; Mikolajewicz et al., 1993) indicated that the flow of deep water through an open seaway would indeed have been from the Caribbean to the Pacific. Steady flow of high $\left[\mathrm{CO}_{3}=\right]$ deep water into the Pacific before $13 \mathrm{Ma}$ would help to explain the high and generally constant levels of carbonate accumulation in the EEP. Third, as discussed by Lyle et al. (this volume), the spatial pattern of the carbonate crash strongly suggests a link to the Panamanian seaway. The affects of the crash were greatest in the eastern Pacific basins near the seaway, such as the Guatemala Basin, where the CCD shoaling was permanent. The affects were less severe in the Pacific Basin, such as at Site 850, where the CCD shoaled only briefly. The second mechanism that may have caused the carbonate crash was a change in NADW flow (Lyle et al., this volume). The two mechanisms are not mutually exclusive, however. The change in deep-water chemistry that produced the crash may have been related to both NADW flow and the closing of the Panamanian seaway. Ocean models suggest that NADW production 
Table 5. Chronology of events marking the closure of the Isthmus of Panama.

\begin{tabular}{|c|c|c|c|}
\hline \multicolumn{2}{|c|}{ Age of event (Ma) } & \multirow[b]{2}{*}{ Source } & \multirow[b]{2}{*}{ Event } \\
\hline $\begin{array}{l}\text { Shackleton } \\
\text { et al. (this } \\
\text { volume) } \\
\text { time scale }\end{array}$ & $\begin{array}{l}\text { Originally } \\
\text { published }\end{array}$ & & \\
\hline & $16.1-15.1$ & Duque-Caro (1990) & $\begin{array}{l}\text { "Tectonic disturbance" triggered the initial uplift of the Panama sill to "lower bathyal depths," } \\
\text { effectively closing the Pacific-Caribbean deep-water connection. Changes in bottom-water } \\
\text { circulation were inferred from near-shore benthic foraminifer assemblage variations and from } \\
\text { sedimentation patterns. }\end{array}$ \\
\hline 13-12 & $12.9-11.8$ & $\begin{array}{l}\text { Duque-Caro (1990) } \\
\text { Keller and Barron } \\
\quad(1983)\end{array}$ & $\begin{array}{l}\text { Panama sill shoaled to about } 1000 \mathrm{~m} \text { ("middle bathyal") based on diversification of benthic } \\
\text { foraminifer fauna. Intermediate-water connection between the Pacific and the Caribbear was } \\
\text { broken. }\end{array}$ \\
\hline $9.9-8.7$ & $9.3-8.0$ & $\begin{array}{l}\text { Marshall (1988) } \\
\text { Webb (1985) } \\
\text { Marshall (1988) }\end{array}$ & $\begin{array}{l}\text { Interchange of some North and South American mammals ("island hoppers") overlaps with the } \\
\text { "carbonate crash." }\end{array}$ \\
\hline 9.5 & & Lyle et al. (this volume) & $\begin{array}{l}\text { Nadir of the "carbonate crash," a dissolution event attributed to the shoaling of the Panama sill } \\
\text { which prevented the flow of less corrosive Caribbean intermediate and deep water into the } \\
\text { Pacific. } \\
\text { Seismic reflector IM-P, formed throughout the equatorial Pacific. }\end{array}$ \\
\hline $9.3-7.8$ & $8.6-7.0$ & Duque-Caro (1990) & $\begin{array}{l}\text { Panama sill shoaled to "upper bathyal" depths based on benthic foraminifer fauna. The shallow } \\
\text { water connection was open. }\end{array}$ \\
\hline $7.8-6.9$ & $7.0-6.3$ & Duque-Caro (1990) & $\begin{array}{l}\text { Sill shoaled to approximately } 150 \mathrm{~m} \text { based on benthic foraminifers. Pacific-Caribbean shallow- } \\
\text { water connection was restricted. }\end{array}$ \\
\hline $6.9-4.0$ & $6.3-3.7$ & Duque-Caro (1990) & Sill shoaled to less than $50 \mathrm{~m}$ based on benthic foraminifer fauna. \\
\hline \multirow[t]{2}{*}{$6.8-6.6$} & $6.2-6.0$ & Keigwin (1982b) & $\begin{array}{l}\text { Shoaling of sill interpreted from increased contrast between Pacific and Caribbean benthic } \\
\text { foraminifer } \delta^{13} \mathrm{C} \text {. Termination of deep-to-intermediate water exchange through the } \\
\text { Pacific-Caribbean gateway. }\end{array}$ \\
\hline & & Keller et al. (1989) & $\begin{array}{l}\text { Planktonic foraminifer faunal assemblage data indicate that significant upwelling began in the } \\
\text { western Caribbean, indicating restricted flow of intermediate-water across the seaway. }\end{array}$ \\
\hline $6.0-3.7$ & & Moore et al. (1993) & $\begin{array}{l}\text { Steep oceanographic gradients formed between the Guatemala and Pacific Basins, as inferred } \\
\text { from the temporal distribution of radiolarian events. These gradients may have been linked to } \\
\text { the flow of Caribbean waters into the Pacific. }\end{array}$ \\
\hline 4.6 & 4.2 & $\begin{array}{l}\text { Keigwin (1982a) } \\
\text { Prell (1982) } \\
\text { Keller et al. (1989) }\end{array}$ & $\begin{array}{l}\text { Caribbean surface-water salinity increased relative to that in the eastern Pacific based on }{ }^{18} \mathrm{O}- \\
\text { enrichment of Caribbean planktonic foraminifers. Changes in the planktonic foraminifer } \\
\text { fauna (greater abundances of } G \text {. sacculifer) also indicated higher salinity in the Caribbean. }\end{array}$ \\
\hline 4.4 & & This chapter & $\begin{array}{l}\text { The locus of maximum opal accumulation abruptly shifted eastward, from Site } 850\left(\sim 0^{\circ} \mathrm{N} \text {, }\right. \\
\left.107^{\circ} \mathrm{W}\right) \text { to Site } 846\left(\sim 3^{\circ} \mathrm{S}, 92^{\circ} \mathrm{W}\right) \text {. }\end{array}$ \\
\hline $4-3$ & & Moore et al. (1993) & $\begin{array}{l}\text { Radiolarian events indicate a northward shift of the southern boundary of the North Equatorial } \\
\text { Countercurrent and a weakening of the oceanographic between the Guatemala and Pacific } \\
\text { basins. }\end{array}$ \\
\hline $4.4-2.6$ & $4.0-2.5$ & $\begin{array}{l}\text { E.g., Kaneps (1970) } \\
\text { Saito (1976) } \\
\text { Keigwin (1978, 1982a) } \\
\text { Lundelius (1987) } \\
\text { Coates et al. (1992) }\end{array}$ & $\begin{array}{l}\text { Complete emergence of the Panama isthmus. Initiation of the Great American Interchange } \\
\text { (vertebrates). Divergence and provinciality of near-shore and open-ocean faunas and floras } \\
\text { increased significantly. }\end{array}$ \\
\hline $2.5-1.9$ & $2.4-1.8$ & $\begin{array}{l}\text { Keller et al. (1989) } \\
\text { Gartner et al. (1987) } \\
\text { Crouch and Poag (1979) }\end{array}$ & $\begin{array}{l}\text { Closure of Pacific-Caribbean gateway and "cessation of sustained surface current flow" (Keller et } \\
\text { al., 1989). Permanent divergence of faunas and floras. }\end{array}$ \\
\hline 1.9 & 1.8 & Keller et al. (1989) & $\begin{array}{l}\text { Maximum divergence of faunal provinces began. "At least incipent littoral-neritic leakage" } \\
\text { occurred cross the seaway until } 1.8 \mathrm{Ma} \text {. }\end{array}$ \\
\hline
\end{tabular}

was related to the restriction of surface-water flow from the Pacific to the Atlantic through the Panamanian seaway (Maier-Reimer et al. 1990; Mikolajewicz et al., 1993). Greater restriction was linked to increased NADW production. Nevertheless, the response of the carbonate system in the equatorial Pacific to greater NADW production is difficult to predict, as previously discussed (Lyle et al., this volume; Berger et al., 1993). Furthermore, our comparison of the chronologies of NADW production and of the carbonate crash suggests that the two are not linked.

We summarized the history of NADW production from 15 to $7 \mathrm{Ma}$ from recent publications (Bohrmann et al., 1990; Wright et al., 1991, 1992) and converted the chronology to Shackleton et al.'s (this volume) time scale. Carbon isotope data suggest little or no production of NADW from 15 to $12.5 \mathrm{Ma}$ (Wright et al., 1992). The initially minor flow of NADW began at $12.5 \mathrm{Ma}$ and was replaced by greater production at either $10.7 \mathrm{Ma}$ (Bohrmann et al., 1990) or $10.3 \mathrm{Ma}$ (Wright et al., 1991). Increased production continued until about 9.9 Ma. From 9.9 to $8.0 \mathrm{Ma}$, NADW production decreased significantly, except for a brief increase near $9.2 \mathrm{Ma}$ (actually, between 9.5 and 8.9 $\mathrm{Ma}$, according to Bohrmann et al., vs. 9.2 to $9.0 \mathrm{Ma}$, according to Wright (pers. comm., 1994).

Variations in NADW production (dubbed the "master modulator" of WEP paleoceanography by Berger et al. (1993)) did not coincide with the EEP sedimentation changes during the carbonate crash. Increased NADW flow between about 10.5 and 9.9 Ma corresponded to the transition from high $\mathrm{CaCO}_{3}$ MARs at 11 Ma to low MARs at 


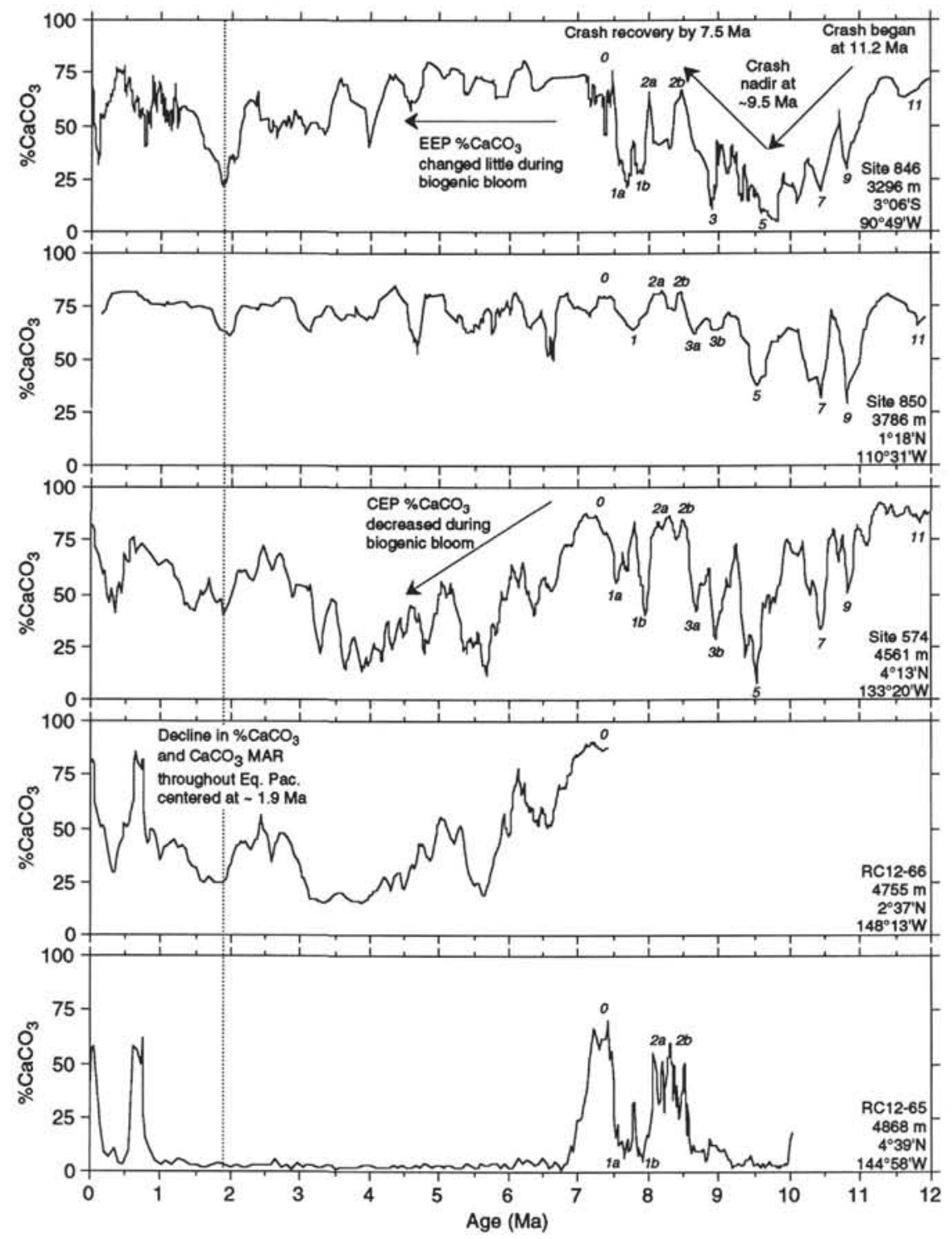

Figure 24. Stratigraphic correlation of $\% \mathrm{CaCO}_{3}$ records from EEP Sites 846 and 850 and from CEP Sites 574, RC12-66, and RC12-65. The carbonate crash began with Event 11 and ended with Event 0 . Maximum dissolution occurred at about $9.5 \mathrm{Ma}$ (Event 5 ). The east-west similarities in the records ended during the biogenic bloom (6.7-4.5 Ma), when changes in the EEP percentage of $\mathrm{CaCO}_{3}$ were minor, although values declined significantly in the CEP. A common decrease in $\% \mathrm{CaCO}_{3}$ was observed at all sites near $1.9 \mathrm{Ma}$ and is discussed by Murray et al. (this volume). The $\% \mathrm{CaCO}_{3}$ records from all sites, except RC12-65, were smoothed with a five-point moving average.

9.5 Ma. The decrease in NADW flow, beginning at 9.9 Ma and continuing beyond $7 \mathrm{Ma}$, also coincided with the transition toward the carbonate crash nadir and with the carbonate recovery as well. The brief interval near 9.2 Ma, when NADW was thought to have ceased, was marked by increased $\mathrm{CaCO}_{3}$ percentages and MARs in the EEP, denoted as Event 4 (Figs. 24 and 25). However, a similar cessation in NADW flow does not appear to have occurred during subsequent carbonate preservation maxima 2 or 0 .

The gross dissimilarity between opal and $\mathrm{CaCO}_{3}$ MARs during the carbonate crash was unusual. Much of the late Neogene record is characterized by generally synchronous changes in $\mathrm{CaCO}_{3}$ and opal MAR, whether they were at high levels, such as during the "bloom," or at moderately low levels, as during the mid-Pliocene (3-4 Ma; Figs. 12 and 13). Although $\mathrm{CaCO}_{3}$ MARs decreased during the crash, the opal MARs (at 9-10 Ma) were generally similar to levels observed during the preceding and following million years (Figs. 13 and 23; Table 4). Some sites exhibited a gradual decline from 11 to $8 \mathrm{Ma}$ (e.g., Sites $844,849,850,851$ ), whereas other sites showed no change (e.g., Sites 845 and 852), or even moderate increases (e.g., Sites 846 and 848 ). If the carbonate crash were related to productivity, and caused by a radical shift in the surface-water ecosystem from carbonate to opal producers, then we might expect to see increased opal MARs (barring an increase in opal dissolution), which was not the case.

\section{"Biogenic Bloom"}

The rates of biogenic accumulation in the EEP between 6.7 and 4.5 Ma were extraordinarily high, even when compared to other late Neogene records from the global ocean. Nevertheless, the pattern of sediment accumulation was not uniform in the EEP. Instead, we observe a 


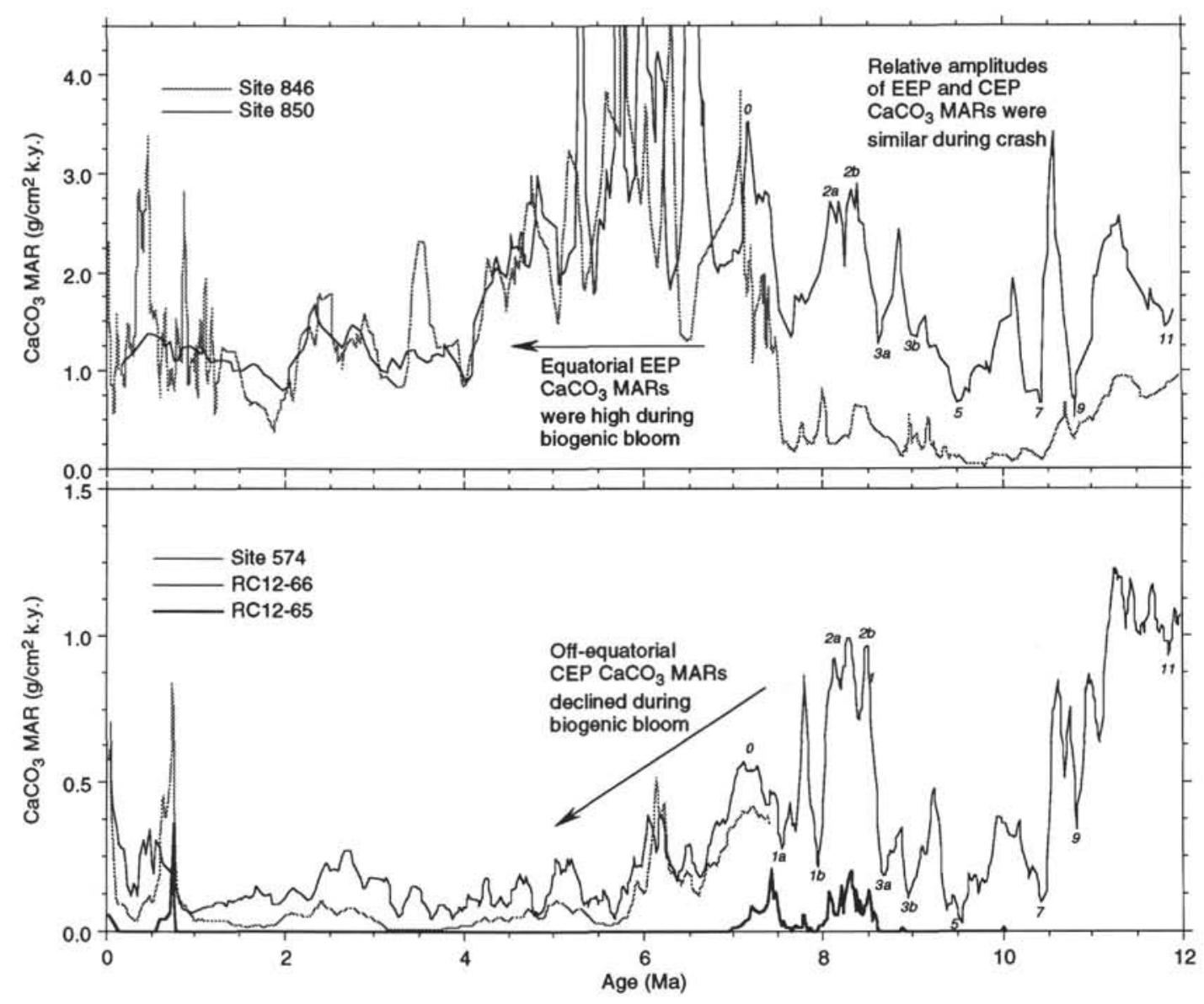

Figure 25. $\mathrm{CaCO}_{3}$ MAR records from Sites 846, 850, 574, RC12-66, and $\mathrm{RC12}-65$ show the same carbonate crash events identified in the $\% \mathrm{CaCO}_{3}$ records (Fig. 24). The relative amplitudes of these MAR records were similar in the EEP and the CEP during the crash $(\sim 11.2-7.5 \mathrm{Ma})$, but were significantly different during the subsequent biogenic bloom $(\sim 6.7-4.5 \mathrm{Ma})$. Note that the MAR scale in the tope figure is three times that in the bottom figure, and that all records, except RC12-65, have been smoothed with a five-point moving average.

complex spatial pattern characterized by a steepening of the latitudinal productivity gradient toward the equator. The biogenic bloom appears to have been concentrated in the tropical Indo-Pacific, although recent evidence indicates it occurred in the North Pacific as well. The wide distribution of this bloom suggests a net increase in the global burial rate of $\mathrm{CaCO}_{3}$ and opal, but additional data will be needed to rule out the possibility of intrabasinal and interbasinal fractionation, which would have resulted in a spatial redistribution of sediment accumulation, rather than a net increase. The bloom has been linked to higher productivity, but the specific mechanisms are uncertain.

\section{Accumulation Patterns in the EEP and CEP}

All Leg 138 sites did not experience increased accumulation during the bloom. For example, accumulation rates in the Guatemala Basin (Sites 844 and 845 ) were actually lower during the bloom (5-6 Ma) than before it (8-9 Ma) (Table 4). At sites where accumulation increased, the rise was not uniform nor always temporally coincident; intrabasinal and interbasinal differences are clearly observed. Accumulation increased in the Galãpagos region, but the peaks in opal and $\mathrm{CaCO}_{3}$ MARs at Sites 846 and 847 often occurred at different times with respect to each other, and with respect to the peaks in the $110^{\circ} \mathrm{W}$ transect sites. For example, the peak at $6.5 \mathrm{Ma}$ in $\mathrm{CaCO}_{3} \mathrm{MARs}$ in the $110^{\circ} \mathrm{W}$ transect sites (Sites 849,850 , and 851 ) was only a minor event in the Site 847 record, and was a valley of low MAR in the Site 846 record (Fig. 25). On the other hand, the $\mathrm{CaCO}_{3} \mathrm{MAR}$ peak at $\sim 5.8 \mathrm{Ma}$ was observed at all equatorial sites except Site 847. Although we think the differences in the times of peak accumulation during the biogenic bloom reflected true variations in sediment accumulation at these sites, we cannot completely eliminate the possibility that the differences are artifacts resulting from inaccuracies in the data, or in the construction of the composite depth sections and age models.

A distinct intrabasinal and latitudinal trend in MARs was noted to be in the $110^{\circ} \mathrm{W}$ transect sites during the biogenic bloom. Comparison of the MARs from 5 to $6 \mathrm{Ma}$ with those from 8 to $9 \mathrm{Ma}$ (Table 4) showed a stronger latitudinal trend in the Pacific Basin (at 5-6 Ma) that was characterized by great increases in MARs at the equatorial sites, but by MAR decreases at the off-equatorial sites. For example, during the interval from 5 to $6 \mathrm{Ma}$, opal and $\mathrm{CaCO}_{3}$ MARs increased by a factor of two or three at equatorial Sites 848 and 849 and by a factor of one or two at Site 850. Sites 851 and 852, farther north, showed no change in MARs, whereas a decrease was recorded at Site 853. The hiatus in Site 854 , the northernmost site in the $110^{\circ} \mathrm{W}$ transect, indicates no net accumulation and perhaps even erosion. Depth-dependent dissolution was not responsible for this latitudinal trend, since the water depths of the sites did not increase with latitude (Table 1). Instead, we attribute the latitudinal flux pattern to a steepening of the productivity gradient characterized by greater production at the equator and by lower production at off-equatorial sites.

Sediments from the CEP, recovered during Leg 85 , also show an enhanced latitudinal gradient in sediment accumulation rates during 
the late Miocene and early Pliocene. Figure 7 in Theyer et al. (1985) shows highest rates at equatorial Site $573\left(133^{\circ} \mathrm{W}, 0.5^{\circ} \mathrm{N}, 4301 \mathrm{~m}\right)$, lower rates at Site $574\left(133^{\circ} \mathrm{W}, 4^{\circ} \mathrm{N}, 4561 \mathrm{~m}\right)$, and a hiatus, or a condensed section, at Site $575\left(135^{\circ} \mathrm{W}, 6^{\circ} \mathrm{N}, 4536 \mathrm{~m}\right)$. Given the small differences in water depth among these sites, we think that an enhanced productivity gradient, rather than depth-dependent dissolution, was primarily responsible for the biogenic accumulation pattern.

From the beginning to the end of the biogenic bloom, $\mathrm{CaCO}_{3}$ MARs progressively declined in the off-equatorial sites in both the CEP, such as Sites 574 and RC12-66 (Fig. 25), and in the EEP, such as Sites 852 and 853 (Fig. 12). $\mathrm{CaCO}_{3}$ percentages also decreased in the CEP, occasionally to the levels reached during the carbonate crash (Fig. 24). This carbonate decline at off-equatorial sites, in both the CEP and the EEP, occurred in the face of significant $\mathrm{CaCO}_{3} \mathrm{MAR}$ increases in the equatorial region of the EEP and the CEP (e.g., Sites 572 and 573; Theyer et al., 1985). We conclude that the response of the carbonate system during the biogenic bloom was clearly bimodal in the tropical Pacific, with distinct equatorial and off-equatorial signals. This bimodal response was significantly different from the uniform response observed during the carbonate crash, when the cross-latitude $\mathrm{CaCO}_{3}$ sedimentation patterns were more similar (Figs. 24 and 25).

The increased frequency of diatom mats in the biogenic bloom interval may be considered evidence of increased opal productivity. However, as previously discussed, some of the EEP peaks in opal MAR during the bloom occurred in sedimentary intervals that contain diatom mats, whereas others do not (Kemp and Baldauf, 1993; Kemp and Baldauf, this volume). We doubt that the opal-MAR peaks that do not correspond to diatom-rich sediments predominantly consist of radiolarians, because such an assemblage would generally imply enhanced $\mathrm{CaCO}_{3}$ dissolution, generally lower sedimentation rates, and reduced MARs. The spatial distribution of the mats is spotty at any given time. In fact, laminations observed in one hole at a site were often not observed in the same sedimentary interval in the adjacent holes (generally less than $30 \mathrm{~m}$ apart; Kemp, pers. comm., 1993). Intersite distribution patterns are also interesting. It is odd that laminations were observed to be between 5 and $6 \mathrm{Ma}$ at Sites 847 and 849 , but not Site 850 . Similarly curious was the observation of mats at Sites 849 and 850 in sediments of between 6 and $7 \mathrm{Ma}$, but not at Site 847 sediments. Finally, why no mats occurred at Site 846, at any time, despite having one of the highest opal concentrations and MARs, was also peculiar. Closer examination of the diatom mats and their stratigraphic distribution is warranted.

What was the fate of the organic carbon $\left(\mathrm{C}_{\mathrm{org}}\right)$ associated with the increased production of opal and $\mathrm{CaCO}_{3}$ organisms during the bloom? Because opal and $\mathrm{CaCO}_{3}$ MARs increased by up to a factor of three at the equatorial sites, we might expect $\% \mathrm{C}_{\mathrm{org}}$ and $\mathrm{C}_{\mathrm{org}}$ MARs to increase, although perhaps not linearly with opal and $\mathrm{CaCO}_{3}$ MARs (Dymond and Lyle, 1994). Results, however, showed that the \% $\mathrm{C}_{\text {org }}$ did not increase. Shipboard measurements of $\% \mathrm{C}_{\text {org }}$ at Sites $846,847,849$, 850 , and 851 indicated values of less than $0.5 \%$ between 6.7 and 4.5 $\mathrm{Ma}$, which were similar to values from the preceding and following million years (Mayer, Pisias, Janecek, et al., 1992). Corg $_{\text {org }}$ MARcreased by up to a factor of two between 6.7 and $4.5 \mathrm{Ma}$, in response to higher sedimentation rates. The absence of higher $\% \mathrm{C}_{\mathrm{org}}$ and $\mathrm{C}_{\mathrm{org}}$ MAR values in the sedimentary record may have been caused by relatively greater remineralization in the water column, or at the sediment/water interface during the biogenic bloom. Today, as much as $85 \%$ of the $\mathrm{C}_{\text {org }}$ reaching the seafloor in the Panama Basin remineralizes within $1 \mathrm{yr}$ (Cole et al., 1987). If a significant portion of the $\mathrm{C}_{\mathrm{org}}$ were incorporated into the surface-sediment mixed layer before degradation, then we might expect $\mathrm{CaCO}_{3}$ dissolution to occur in response to the addition of $\mathrm{CO}_{2}$ to the pore waters (Emerson and Bender, 1981). Whether the degree of dissolution was large enough to be recognized in the sedimentary record depends on the $\left[\mathrm{CO}_{3}{ }^{ }\right]$of the overlying waters and on the rain ratio of $\mathrm{C}_{\mathrm{org}}: \mathrm{C}_{\mathrm{CaCO}}$. The nannofossil data, however, suggest good $\mathrm{CaCO}_{3}$ preservation during the bloom, even at the off-equatorial sites.

\section{Global Extent of the Biogenic Bloom}

The bloom was not restricted to the EEP, as shown by Leg 85 results from the CEP (Theyer et al., 1985, 1989) and by Leg 130 results from the WEP (Berger et al., 1993). All Pacific equatorial regions experienced a dramatic increase in MAR during the Tortonian-Messinian interval. Sedimentation rates in the WEP were highest near the Miocene/Pliocene boundary, peaking at about $6.6 \mathrm{Ma}$ (e.g., see fig. 12 in Berger et al., 1993). Compelling evidence that the biogenic bloom occurred throughout the entire tropical Indo-Pacific was presented by Peterson et al. (1992), who showed large $\mathrm{CaCO}_{3}$ MAR increases in the Arabian Sea (Leg 117), on the Mascarene Plateau (Leg 115), on the Ninetyeast Ridge (Leg 121), and on the northwest Australian Margin (Leg 122) between 7 and $4 \mathrm{Ma}$. Whether such a "bloom" occurred in the tropical Atlantic remains to be seen.

Evidence of a biogenic bloom has been found in some high-latitude regions, but not others. The bloom was not observed at the Kerguelen Plateau, in the southern Indian Ocean (Leg 119/120) (Peterson et al., 1992; Barron, Larsen, et al., 1991; Schlich, Wise, et al., 1989). In fact, this interval is characterized by hiatuses at most sites. In other regions, however, a major increase in opal MARs occurred in the Southern Ocean at about 5.5 Ma (Barron and Baldauf, 1989; Brewster, 1980). This high-latitude increase was thought to have coincided with a significant decline in equatorial Pacific opal MARs (Leinen, 1979), but the Leg 138 results do not support a "switching off" of opal MAR in the EEP at this time. On the contrary, we observed high opal MARs in the EEP(Fig. 12). In the northern high latitudes, opal MARs increased significantly between 7 and $4 \mathrm{Ma}$ (Leg 145 Shipboard Scientific Party, 1993), whereas $\mathrm{CaCO}_{3}$ MARs, at least at Site 882, were variable and low (G. Haug, pers. comm., 1993).

\section{Speculations Concerning the Cause of the Bloom}

The biogenic bloom is thought to have been caused by increased productivity (Peterson et al., 1992; Berger et al., 1993). Berger et al.'s productivity hypothesis was based on microfossil and $\delta^{13} \mathrm{C}$ data and predicated on the idea that the bloom resulted from greater nutrient concentrations in Pacific waters caused by increased production of NADW (basin-basin fractionation). However, a temporal link between NADW flow and the biogenic bloom is not apparent. Reconstructions suggest reduced NADW flow from 7.8 to $6.3 \mathrm{Ma}$ (Wright et al., 1991) and increased flow from 6.4 to $5.9 \mathrm{Ma}$ (Bohrmann et al., 1991); these intervals are not closely linked to either the initiation or the culmination of the biogenic bloom. Nevertheless, if circulation changes did result in greater nutrient concentrations in the Pacific, increased opal production would have been likely. Diatom abundances increased in the WEP, but not significantly, and Berger et al. attributed this to extraction of silica in upwelling systems in the Southern Ocean and in coastal regions. This silica fractionation model is not consistent with the high opal MARs observed during the bloom in the EEP and in the North Pacific (Leg 145 Shipboard Scientific Party, 1993) that are outside the influence of coastal upwelling. The WEP-EEP difference in opal MAR remains to be explained. One possibility is that the upwelling of silica into the surface waters of the WEP was less than that in the EEP, as observed today. Enhanced flow of the EUC and a thickening of the mixed layer in the WEP may have increased silica injection into the surface waters of the EEP and decreased it in the WEP. On the other hand, if the silicainjection levels were similar, then perhaps the greater MAR levels in the EEP can be explained by longitudinal differences in a variety of parameters, such as silica dissolution, surface-water ecosystems, bulk sedimentation rates, or micronutrient distributions.

A likely consequence of increased production on a near-global scale would be an expansion of the intermediate water oxygen minimum zone (OMZ) (Woodruff et al., 1981). Geochemical and faunal evidence of such an expansion has been observed in upper Miocenelower Pliocene sediments from the Indian Ocean (Dickens and Owen, 
1994). These authors identified sedimentary intervals with lower Mn fluxes and $\mathrm{Mn} / \mathrm{Sc}$ ratios and attributed them to a productivity-induced expansion of the OMZ.

Critical to the interpretation of the biogenic bloom is determining whether it represented a global increase in the burial rates of $\mathrm{CaCO}_{3}$ and opal or whether it represented a large-scale redistribution of these materials within the ocean, resulting in no net increase in burial rates. If the ocean maintains itself at steady state with respect to the carbonate and opal systems, then global increases in burial must be balanced by greater influxes of $\mathrm{Ca}, \mathrm{Si}$, and nutrients to the ocean. If the bloom represents fractionation of $\mathrm{CaCO}_{3}$ and opal within, and between, ocean basins, then no change in $\mathrm{Ca}$ and $\mathrm{Si}$ influxes to the ocean is required. Distinguishing between these two possibilities will require quantitative flux data from more regions in the global ocean. With such data, we may find that MAR increases in regions such as the equatorial Pacific were offset by MAR decreases in other regions, such as continental margins and perhaps the Atlantic. With respect to the possibility of intrabasinal redistribution, we have observed a latitudinal fractionation of $\mathrm{CaCO}_{3}$ and opal MARs in the EEP and the CEP, characterized by increased MARs at the equator and decreased MARs at off-equatorial sites. This MAR pattern is evidence for a redistribution of accumulation, rather than a global increase, but more data will be needed to determine the mass balance.

The ultimate cause of the MAR increase in the tropics is unknown, but it has been linked to such global-scale processes as sea level, continental weathering, deep-water circulation, and trade-wind fluctuations (Peterson et al., 1992, and references therein). The initiation of the bloom corresponds to a shoaling of the Panamanian sill at about 6.6 to $6.8 \mathrm{Ma}$ (Table 5), but attribution of tropical Indian Ocean sedimentary patterns to this event may be difficult. The bloom was also coeval with the Messinian salinity crisis and the growth of the West Antarctic ice sheet (Kennett, 1985; Theyer et al., 1989), but a causative link has not been established.

\section{"Opal Shift" and the Closure of the Panamanian Seaway}

The late Neogene closure of the Panamanian seaway isolated the Caribbean from the Pacific and significantly affected global circulation patterns. Although most attention has previously been focused on the final closure at $4 \mathrm{Ma}$, which resulted in the isolation of surface waters of these basins, geologic data suggest that restriction of deepwater flow appears to have begun as early as 12 or $13 \mathrm{Ma}$. Our understanding of this seaway closure, and the paleoceanographic ramifications, are based on recent ocean modeling efforts, previously published geologic data, and results from Leg 138, all of which are summarized below.

\section{Implications of Models}

General ocean circulation models indicate that opening the seaway results in a collapse of the thermohaline circulation cell in the North Atlantic and a marked reduction in the formation of NADW (Maier-Reimer et al., 1990; Mikolajewicz et al., 1993). This result was attributed to the injection of low salinity surface waters from the EEP into the Caribbean and, ultimately, the North Atlantic. The direction of this flow is controlled by the difference in hydrostatic head between the Pacific and the Atlantic Oceans. Today, the surface topography in the equatorial Pacific Ocean is as much as $80 \mathrm{~cm}$ higher than in the equatorial Atlantic, because the Pacific has a longer fetch in the trade winds and is less salty (Maier-Reimer et al., 1990). In response to the hydrostatic head, the model predicts a surface-water flow of $10 \mathrm{~Sv}$ from the EEP to the Caribbean. This flow was only slightly countered by a flow of $1 \mathrm{~Sv}$ in the opposite direction, which was attributed to forcing by trade winds. Given these results from modeling, we think the $10-\mathrm{Sv}$ flow from the EEP would largely consist of waters from the NECC, which today transports about $20 \mathrm{~Sv}$
(Wyrtki and Klonsky, 1984) of nutrient-depleted water to the east. The waters in the 1-Sv flow from the Caribbean would be warm, saline, and nutrient-depleted, compared to most surface water in the EEP. With respect to deep water, the Hamburg model indicates flow from the Caribbean to the Pacific, because of colder bottom waters in the Atlantic sector (Maier-Reimer et al. 1990; Mikolajewicz et al., 1993). This is consistent with the flow direction inferred by Lyle et al. (this volume).

In a comparison of two modeling runs, with the isthmus open and closed, and with atmospheric forcing fixed at present-day conditions in both runs, Maier-Reimer et al. (1990) observed little difference in EEP upwelling, which was estimated from the vertical velocity field. Paleoceanographic data from Hayes et al. (1989) were cited as supporting evidence that the final closing of the seaway had little influence on upwelling, as recorded by radiolarian assemblages.

Despite these results, we raise three points that suggest the opening and closing of the seaway may have had a larger impact on the sedimentary record in the EEP than previously implied. First, as noted by Maier-Reimer et al. (1990), upwelling may have been greater if atmospheric forcing were not fixed in the model and if changes were made in the horizontal size of the seaway opening and in the sill depth. Second, constancy in the vertical velocity field does not necessarily imply constancy in the temperature nor the nutrient content of the upwelled waters and thus in surface-water productivity. If the $1-\mathrm{Sv}$ flow of surface waters from the Caribbean depressed the thermocline, in at least a portion of the EEP, then surface-watter ecology would have changed and primary production would have probably decreased. Thus, primary production and sediment accumulation may have been affected by the seaway closure, whereas the vertical velocity field would not have been affected. This scenario is analogous to a comparison between the modern WEP and the EEP. The upwelling velocity in the EEP is only slightly higher than that in the WEP (whereas the highest velocity is in the CEP) (Maier-Reimer et al., 1990; Xie and Hsieh, in press). Nevertheless, productivity levels decline significantly to the west (Berger et al., 1987), because of the progressive thickening of the surface mixed layer. Upwelling in the EEP taps into the cold and nutrient-enriched Equatorial Undercurrent, which fuels high productivity. Upwelled waters in the WEP are warm and nutrient-depleted, because they are derived from the base of the mixed layer. As such, WEP productivity levels are lower. Because vertical velocity is not directly linked to the temperature and nutrient-content of upwelled waters nor to primary production, we think that the closure of the seaway probably changed flow patterns and influenced the spatial distribution of productivity, if not its overall level. The third point is that the paleoceanographic data from Hays et al. (1989) may not be relevant for resolving paleoceanographic change associated with the closure of the seaway. This is because their data extend only to $3.8 \mathrm{Ma}$, which may post-date the closure and because their core site is possibly too far to the west $\left(114^{\circ} \mathrm{W}\right)$ to have experienced oceanographic change associated with the closure, which occurred at about $80^{\circ}$ to $85^{\circ} \mathrm{W}$.

\section{Geologic History of the Closure of the Panamanian Seaway}

The geologic history of the Panama sill uplift and the isolation of Caribbean and EEP waters has been reconstructed from sedimentary records from deep-sea (e.g., Saito, 1976; Keigwin, 1978, 1982a, 1982b; Keller et al., 1989; Moore et al., 1993), near-shore (DuqueCaro, 1990; Coates et al., 1992; Knowlton et al., 1993), and terrestrial environments (Lundelius, 1987; Marshall, 1988). This history has been difficult to reconstruct for several reasons. First, the nature and rate of tectonic evolution in the region remain enigmatic (e.g., Mann and Burke, 1984; Mann and Corrigan, 1990). Second, the emergence of the Panamanian isthmus may have been episodic and perhaps not even unidirectional. For example, an interchange of some terrestrial mammals occurred several million years before the final closure, which precipitated the Great American Interchange (Marshall, 1988). 


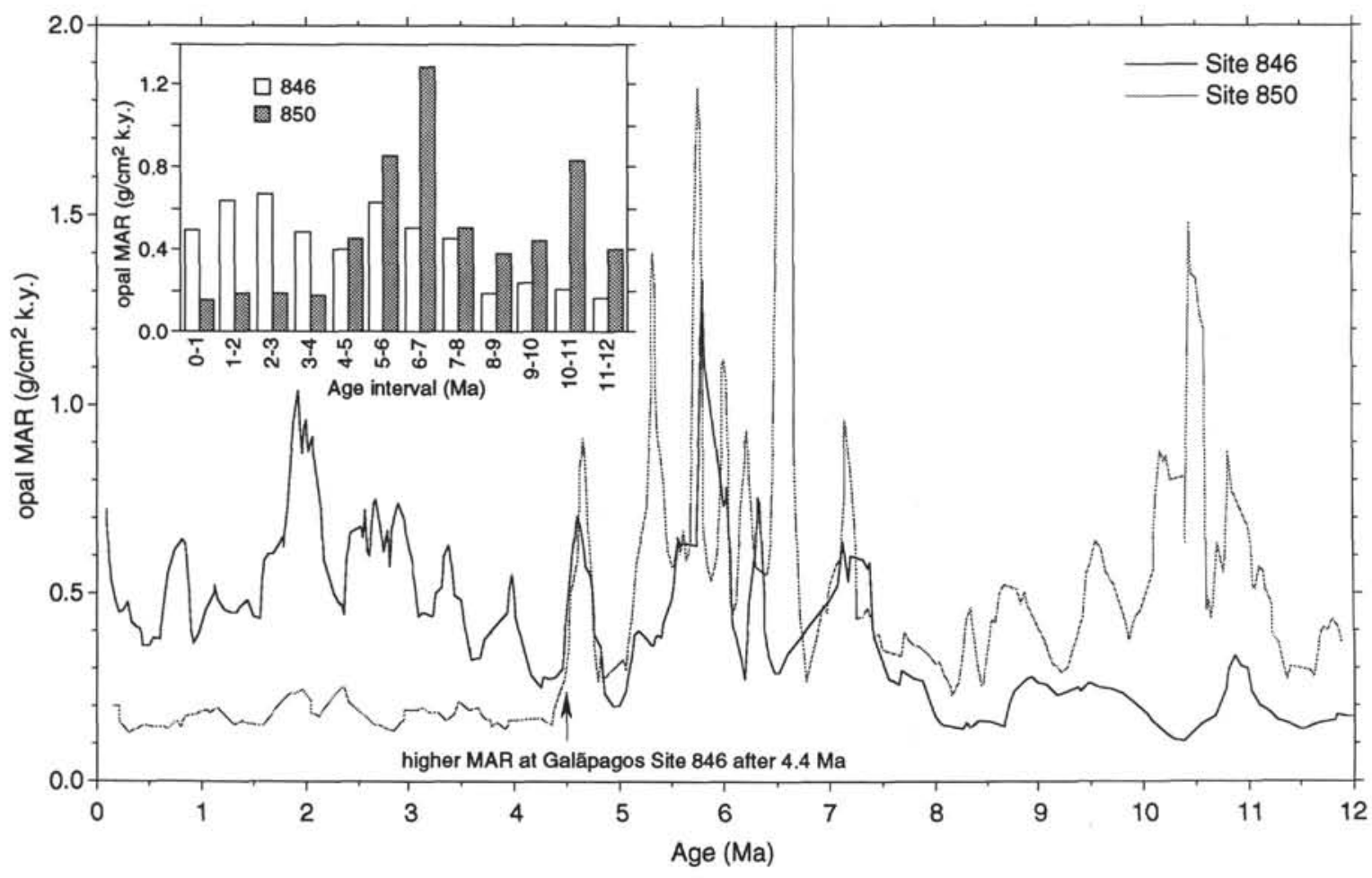

Figure 26. Opal MAR records from the Galãpagos region (Sites 846) and the equatorial zone of the $110^{\circ} \mathrm{W}$ transect (Site 850 ) show the shift in the locus of maximum opal accumulation at $4.4 \mathrm{Ma}$. At that time, which has been associated with the final closure of the Panamanian seaway, opal MARs declined sharply in the Pacific Basin and increased in the Galãpagos region. The records have been smoothed with a five-point moving average. Histogram (inset) shows the opal shift between 3-4 and 4-5 Ma, when the data are expressed as 1-m.y. averages.

Finally, reconstruction of the Panama sill depth, and thus the water masses that flowed between the Caribbean and the Pacific, has often been based on foraminifer faunal assemblage data that are difficult to link accurately to water depth (Duque-Caro, 1990). Despite these difficulties, we have compiled and summarized (Table 5) the results of recent efforts to reconstruct events in the geologic history of the closure of the Panamanian seaway. The events are listed in chronological order, with the age estimates as originally published and as converted to Shackleton et al.'s (this volume) time scale. The results of the various studies do not necessarily agree, especially in terms of the sill depth and the timing of flow constriction. Nevertheless, a general consensus emerges.

The earliest indication of seaway closure occurred between 13 and $12 \mathrm{Ma}$ (Table 5), which was temporally coincident with the large swings in $\% \mathrm{CaCO}_{3}$ and $\mathrm{CaCO}_{3}$ MAR in Sites 844 and 845 (Fig. 15) that signaled the onset of the carbonate crash. This time also coincides with the initial formation of Northern Component Water, the precursor of NADW (Wright et al., 1992). Shoaling of the Panama sill to the point that some mammals were able to interchange between the Americas, between 10 and $9 \mathrm{Ma}$, coincides with the nadir of the carbonate crash and the age of seismic Reflector IM-P (Mayer et al., 1986; Bloomer et al., this volume). Caribbean-Pacific differences in foraminifer faunal assemblages and in benthic foraminifer carbon isotopes between 9 and about 5 Ma suggest continued isolation of the two basins (Table 5). A large body of evidence suggests that the final closure occurred between 4.6 and $2.6 \mathrm{Ma}$ (Table 5). Surface waters in the Caribbean appear to have become significantly saltier than those in the EEP at about $4.6 \mathrm{Ma}$, based on the divergence of planktonic foraminifer $\delta^{18} \mathrm{O}$ (Keigwin, $1982 \mathrm{a}, 1982 \mathrm{~b}$ ) and changes in the planktonic foraminifer assemblage (Keller et al., 1989). These events, which argue for a cessation of surface current flow across the Panamanian seaway, coincide with the eastward shift in the locus of maximum opal accumulation observed in the Leg 138 sites, discussed below.

\section{Results from Leg 138}

Previous work on Leg 138 sediments described in detail, the impact of the seaway closure on radiolarian events (Moore et al., 1993) and on carbonate dissolution (Lyle et al., this volume). Here, we add to this research by linking the shift in the locus of maximum opal accumulation at $4.4 \mathrm{Ma}$ to the final emergence of the isthmus (Fig. 26). Before $4.4 \mathrm{Ma}$, the highest opal MARs were at the $110^{\circ} \mathrm{W}$ transect sites (Sites 849 and 850), which remained within two degrees of the equator since forming at about $12 \mathrm{Ma}$. The opal MARs in the Galãpagos region (Site 846) were consistently lower until 4.4 Ma. At that time, there was a distinct and permanent decline in the opal MAR at Site 850 and in the amplitude of MAR fluctuations. At Site 846, however, opal MAR gradually increased after $4.4 \mathrm{Ma}$, often reaching, or even exceeding, values similar to those recorded during the biogenic bloom interval, between 6.7 and $4.5 \mathrm{Ma}$. Opal MAR values at Site 846 generally ranged between 0.4 and $1.0 \mathrm{~g} / \mathrm{cm}^{2} / \mathrm{k}$.y. after $4.4 \mathrm{Ma}$, whereas those at Site 850 were less than $0.3 \mathrm{~g} / \mathrm{cm}^{2} / \mathrm{k}$.y. Closer examination of the shift in the opal MAR pattern shows that it was the result of changes in sedimentation rate and in opal percentage. Figure 27 shows that during the biogenic bloom $(6.7-4.5 \mathrm{Ma})$, sedimentation patterns at Sites 846 and 850 were similar. Sedimentation rates, opal and $\mathrm{CaCO}_{3} \mathrm{MARs}$, and \%opal and $\% \mathrm{CaCO}_{3}$ covaried at the two sites. Just after the bloom, at about $4.4 \mathrm{Ma}$, the sedimentation rates, \%opal, and opal MARs declined at Site 850 but increased at Site 846. The level of $\mathrm{CaCO}_{3}$ MAR declined at both sites, but no intersite difference developed in $\mathrm{CaCO}_{3}$ MARs. The similarity in the $\mathrm{CaCO}_{3}$ MARs at the two sites reflects the balance between the relative increase in $\% \mathrm{CaCO}_{3}$ and DBD at Site 850 and the relative decrease in sedimentation rates.

Despite the warning from Archer et al. (1993), we interpret higher opal MARs in the EEP as a reflection of greater diatom production, which in turn is attributed to greater nutrient influx to the surface waters. Archer et al. (1993) suggested that opal MAR reflects a signifi- 

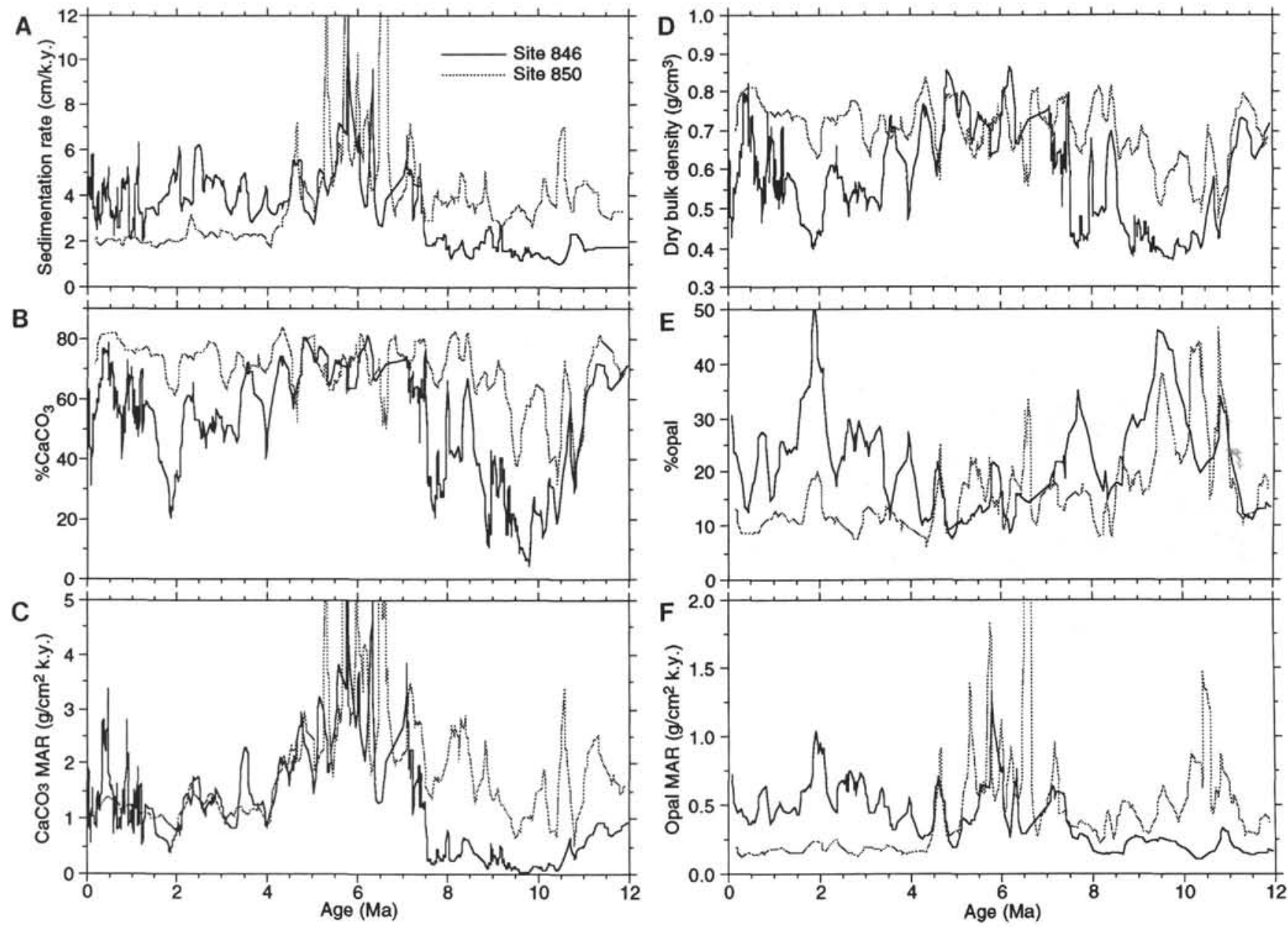

Figure 27. Sedimentary records show that the "opal shift" at $4.4 \mathrm{Ma}(\mathbf{F})$ resulted from a relative increase in both sedimentation rate (A) and opal percentage (E) at Site 846 compared to Site $850 . \mathrm{CaCO}_{3}$ MAR variations (C) at the two sites have remained similar since $7 \mathrm{Ma}$. No intersite $\mathrm{CaCO}_{3} \mathrm{MAR}$ difference began at $4.4 \mathrm{Ma}$ because the relative decrease in sedimentation rates at Site 850 was offset by relatively higher $\% \mathrm{CaCO}_{3}(\mathrm{~B})$ and DBD $(\mathrm{D})$ values at Site 850 .

cant artifact of dilution by other sedimentary components, primarily $\mathrm{CaCO}_{3}$ in the EEP. From a theoretical standpoint, they argued that the $\%$ opal was a better reflector than opal MAR as an index of surfacewater opal production, although they admitted that present-day \%opal data in tropical regions show little or no systematic trend with the flux of opal from the surface waters, whereas opal MAR does (Dymond and Lyle, 1994). Beginning at 4.4 Ma, both opal MAR and \%opal increased at Site 846, relative to Site 850 , whereas no intersite differences in $\mathrm{CaCO}_{3} \mathrm{MAR}$ are observed. These observations bolster our interpretation of opal MAR as an opal paleoproductivity index in this region. In general, opal accumulates in the EEP, but not in significant quantities in the WEP (Lange and Berger, 1993), despite $\mathrm{CaCO}_{3}$ MAR levels that are often similar in the two regions. This east-west difference in opal MAR is linked to the ecology of the surface waters. The EEP hosts a phytoplankton assemblage dominated by diatoms, which flourishes in the nutrient-rich waters (Dymond and Lyle, 1985), whereas in the relatively nutrient-depleted WEP, the phytoplankton assemblage is dominated by coccoliths. In general terms, the eastward shift in the locus of maximum opal MAR at 4.4 Ma can be explained by a tectonicallyinduced change in oceanography that caused nutrients to become more available at Site 846 and less available at Site 850 . We speculate that the shift was related to a disturbance in the surface-water flow regime possibly caused by the cessation of NECC outflow into the Caribbean, resulting in the "backup" of these waters in the EEP, and by the elimination of the minor flow of nutrient-depleted Caribbean waters into the EEP.

\section{CONCLUSIONS}

The accumulation rates of biogenic material have varied greatly in the EEP since the middle Miocene ( $13 \mathrm{Ma}$ ), but the spatial pattern of accumulation has remained relatively constant, with highest values near the equator.

A "carbonate crash" occurred between $\sim 11.2$ and $7.5 \mathrm{Ma}$, when $\mathrm{CaCO}_{3}$ concentrations and MARs declined precipitously, nannofossil preservation was poor, and the CCD shoaled by as much as $1400 \mathrm{~m}$. Opal deposition, however, continued unchanged across this interval. Recovery from the crash was completed by $7.5 \mathrm{Ma}$, except at the Guatemala Basin sites, which remained below the regional CCD. The crash has been identified throughout the tropical Pacific and has been attributed to a tectonically induced change in deep-water circulation across the Panamanian seaway (Lyle et al., this volume).

The highest sedimentation accumulation rates observed in the Leg 138 records occurred between 6.7 and $4.5 \mathrm{Ma}$, when $\mathrm{CaCO}_{3}$ and opal MARs increased between two- and eight-fold at equatorial sites. This great rise in biogenic MARs was not restricted to the EEP; similar increases have been observed throughout tropical Indo-Pacific. This bloom has been attributed to a large-scale increase in surface-water productivity, although specific causal mechanisms remain speculative.

At $4.4 \mathrm{Ma}$, a distinct and permanent eastward displacement in the locus of maximum opal MAR occurred from the Pacific Basin (Site 850 ) to the Galãpagos region (Site 846). This has been attributed to a 
shift in nutrient availability that was temporally, and perhaps causally, linked with the final closure of the Panamanian seaway.

Large-scale changes in deposition were not observed at times corresponding to the initiation of Northern Hemisphere glaciation ( $2.7 \mathrm{Ma})$, nor the shift toward 100-k.y. cyclicity in ice-volume fluctuations during the Pleistocene $(\sim 800 \mathrm{ka})$. This suggests that cryosphere fluctuations, which clearly influenced the sedimentary record at high northern latitude ocean sites (e.g., Leg 145), had less impact of an impact in the EEP. Instead, gross changes in EEP sedimentation patterns are more closely linked to regional events, such as seaway openings and closings.

\section{ACKNOWLEDGMENTS}

We are indebted to the crew and scientific party of Leg 138 for their hard work and generous collaboration, which led to the collection of such fine data. We thank many colleagues, especially Larry Mayer, Nick Pisias, Nick Shackleton, Alan Mix, Jim Wright, and Steve Bloomer for providing helpful information, stimulating E-mail conversation, and useful suggestions. The manuscript benefited by thoughtful reviews from Larry Peterson and James Gardner. Financial support from the U.S. National Science Foundation (through JOI/USSAC Grants TAMRF-20528 to JF and TAMRF-20590 to TJ) is gratefully acknowledged.

\section{REFERENCES $*$}

Archer, D., Lyle, M., Rodgers, K., and Froelich, P., 1993. What controls opal preservation in tropical deep-sea sediments? Paleoceanography, 8:7-21.

Arrhenius, G., 1952. Sediment cores from the East Pacific. In Pettersson, H. (Ed.), Rep. Swed. Deep-Sea Exped. 1947-1948, 5:189-201.

Barron, J., Larsen, B., et al., 1991. Proc. ODP, Sci. Results, 119: College Station, TX (Ocean Drilling Program).

Barron, J., Nigrini, C.A., Pujos, A., Saito, T., Theyer, F., Thomas, E., and Weinrich, N., 1985a. Synthesis of biostratigraphy, central Equatorial Pacific, Deep Sea Drilling Project Leg 85: refinement of Oligocene to Quaternary biochronology. In Mayer, L., Theyer, F., Thomas, E., et al., Init. Repts. DSDP, 85: Washington (U.S. Govt. Printing Office), 905-934.

Barron, J.A., and Baldauf, J.G., 1989. Tertiary cooling steps and paleoproductivity as reflected by diatoms and biosiliceous sediments. In Berger, W.H., Smetacek, V., and Wefer, D. (Eds.), Productivity of the Ocean: Present and Past: Chichester (Wiley), 341-354.

Barron, J.A., Keller, G., and Dunn, D.A., 1985b. A multiple microfossil biochronology for the Miocene. In Kennett, J.P. (Ed.), The Miocene Ocean: Paleoceanography and Biogeography. Mem.-Geol. Soc. Am., 163:21-36.

Berger, W.H., Fisher, K., Lai, C., and Wu, G., 1987. Ocean productivity and organic carbon flux. Part I. Overview and maps of primary production and export production. Univ. of California, San Diego, SIO Reference 97-30.

Berger, W.H., Leckie, R.M., Janecek, T.R., Stax, R., and Takayama, T., 1993. Neogene carbonate sedimentation on Ontong Java Plateau: highlights and open questions. In Berger, W.H., Kroenke, L.W., Mayer, L.A., et al., Proc. ODP, Sci. Results, 130: College Station, TX (Ocean Drilling Program), 711-744.

Berggren, W.A., Kent, D.V., Flynn, J.J., and Van Couvering, J.A., 1985. Cenozoic geochronology. Geol. Soc. Am. Bull., 96:1407-1418.

Bohrmann, G., Henrich, R., and Thiede, J., 1990. Miocene to Quaternary paleoceanography in the northern North Atlantic: variability in carbonate and biogenic opal accumulation. In Bleil, U., and Thiede, J. (Eds.), Geological History of the Polar Oceans: Arctic versus Antarctic. NATO ASI Series C, 647-675.

Brewster, N.A., 1980. Cenozoic biogenic silica sedimentation in the Antarctic Ocean. Geol. Soc. Am. Bull., 91:337-347.

Bryden, H.L., and Brady, E.C., 1985. Diagnostic model of the three-dimensional circulation in the upper Equatorial Pacific Ocean. J. Phys. Oceanogr., 15:1255-1273

\footnotetext{
-Abbreviations for names of organizations and publications in ODP reference lists follow the style given in Chemical Abstracts Service Source Index (published by American Chemical Society).
}

Chavez, F.P., and Barber, R.T., 1987. An estimate of new production in the equatorial Pacific. Deep-Sea Res. Part A, 34:1229-1243.

Coates, A.G., Jackson, J.B., Collins, L.S., Cronin, T.M., Dowsett, H.J., Bybell, L.M., Jung, P., and Obando, J.A., 1992. Closure of the Isthmus of Panama: the near-shore marine record of Costa Rica and Western Panama. Geol. Soc. Am. Bull., 104:814-828.

Cole. J.J., Honjo, S., and Erez, J., 1987. Benthic decomposition of organic matter at a deep-water site in the Panama Basin. Nature, 327:703-704.

Cox, A., and Engebretson, D., 1985. Changes in motion of the Pacific plate at 5 Myr BP. Nature, 313:472-474.

Crouch, R.W., and Poag, W.C., 1979. Amphistegina gibbosa D'Orbigny from the California borderlands: the Caribbean connection. J. Foraminiferal Res., 9:85-105.

Demets, C., Gordon, R.G., Argus, D.F., and Stein, S., 1990. Current plate motions. Geophys. J. Int., 101:425-478.

Dickens, G.R., and Owens, R.M., 1994. Late Miocene-early Pliocene manganese redirection in the central Indian Ocean: expansion of the intermediate water oxygen minimum zone. Paleoceanography, 9:169-181.

Duncan, R.A., and Clague, D.A., 1985. Pacific plate motion recorded by linear volcanic chains. In Nairn, A.E.M., Stehli, F.G., and Uyeda, S. (Eds.), The Ocean Basins and Margins (Vol. 7A): The Pacific Ocean: New York (Plenum), 89-121.

Dunn, D.A., and Moore, T.C., Jr., 1981. Late Miocene-Pliocene (magnetic epoch 9-Gilbert magnetic epoch) calcium-carbonate stratigraphy of the equatorial Pacific Ocean. Geol. Soc. Am. Bull., 92:104-107.

Duque-Caro, H., 1990. Neogene stratigraphy, paleoceanography and paleobiogeography in the northwest South America and the evolution of the Panama Seaway. Palaeogeogr., Palaeoclimatol., Palaeoecol., 77:203-234.

Dymond, J., and Lyle, M., 1985. Flux comparisons between sediments and sediment traps in the eastern tropical Pacific: implications for atmospheric $\mathrm{CO}_{2}$ variations during the Pleistocene. Limnol. Oceanogr., 30:699-712.

, 1994. Particle fluxes in the ocean and implications for sources and preservation of ocean sediments. In Hey, W. (Ed.), Material Fluxes on the Surface of the Earth: Washington, D.C. (National Academy Press).

Emerson, S., and Bender, M., 1981. Carbon fluxes at the sediment-water interface of the deep-sea: calcium carbonate preservation. J. Mar. Res., 39:139-162.

Farrell, J.W., and Janecek, T.R., 1991. Late Neogene paleoceanography and paleoclimatology of the northeast Indian Ocean (Site 758). In Weissel, J., Peirce, J., Taylor, E., Alt, J., et al., Proc. ODP, Sci. Results, 121: College Station, TX (Ocean Drilling Program), 297-358.

Farrell, J.W., and Prell, W.L., 1991. Pacific $\mathrm{CaCO}_{3}$ preservation and $\delta^{18} \mathrm{O}$ since 4 Ma: paleoceanic and paleoclimatic implications. Paleoceanography, 6:485-498.

Farrell, J.W., III, 1991. Late Neogene paleoceanography of the central Equatorial Pacific: evidence from carbonate preservation and stable isotopes [Ph.D. dissert.]. Brown Univ., Providence, RI.

Fiedler, P.C., Philbrick, V., and Chavez, F.P., 1991. Oceanic upwelling and productivity in the eastern tropical Pacific. Limnol. Oceanogr., 36:1834 1850.

Flöhn, H., 1978. Climate and Weather: New York (McGraw-Hill).

Foster, J.H., and Opdyke, N.D., 1970. Upper Miocene to Recent magnetic stratigraphy in deep-sea sediments. J. Geophys. Res., 75:4465-4473.

Gartner, S., Chow, J., and Stanton, R.J., 1987. Late Neogene paleoceanography of the eastern Caribbean, the Gulf of Mexico and the eastern equatorial Pacific. Mar. Micropaleontol., 12:255-304.

Hagelberg, T., Shackleton, N., Pisias, N., and Shipboard Scientific Party, 1992. Development of composite depth sections for Sites 844 through 854. In Mayer, L., Pisias, N., Janecek, T., et al., Proc. ODP, Init. Repts., 138 (Pt. 1): College Station, TX (Ocean Drilling Program), 79-85.

Haq, B.U., Hardenbol, J., and Vail, P.R., 1987. Chronology of fluctuating sea levels since the Triassic. Science, 235:1156-1167.

Hayes, S.P., Mangum, L.J., Barber, R.T., Huyer, A., and Smith, R.L., 1986. Hydrographic variability west of the Galãpagos Islands during the 198283 El Niño. Prog. Oceanogr., 17:137-162.

Hays, P.E., Pisias, N.G., and Roelofs, A.K., 1989. Paleoceanography of the eastern equatorial Pacific during the Pliocene: a high-resolution radiolarian study. Paleoceanography, 4:57-73.

Herbert, T.D., and Mayer, L.A., 1991. Long climatic time series from sediment physical property measurements. J. Sediment. Petrol., 61:1089-1108.

Hey, R., 1977. Tectonic evolution of the Cocos-Nazca spreading center. Geol. Soc. Am. Bull., 88:1404-1420.

Hey, R., Johnson, G.L., and Lowrie, A., 1977. Recent plate motions in the Galãpagos area. Geol. Soc. Am. Bull., 88:1385-1403. 
Hofmann, E.E., Busalacchi, A J., and O'Brian, J.J., 1981. Wind generation of the Costa Rica Dome. Science, 214:552-554.

Jackson, J.B.C., Jung, P., Coates, A.G., and Collins, L.S., 1993. Diversity and extinction of tropical American mollusks and emergence of the Isthmus of Panama. Science, 260:1624-1626.

Jones, G.A., and Kaiteris, P., 1983. A vacuum-gasometric technique for rapid and precise analysis of calcium carbonate in sediments and soils. $J$. Sediment. Petrol., 53:655-660.

Kaneps, A.G., 1970. Late Neogene (late Miocene to Recent) biostratigraphy (planktonic foraminifers), biogeography and depositional history, Atlantic Ocean, Caribbean sea, Gulf of Mexico [Ph.D. dissert.]. Columbia Univ., New York.

Karlin, R., Lyle, M., and Zahn, R., 1992. Carbonate variations in the Northeast Pacific during the late Quaternary. Paleoceanography, 7:43-61.

Keigwin, L.D., 1978. Pliocene closing of the Isthmus of Panama, based on biostratigraphic evidence from nearby Pacific Ocean and Caribbean Sea cores. Geology, 6:630-634.

1982a. Isotopic paleoceanography of the Caribbean and East Pacific: role of Panama uplift in late Neogene time. Science, 217:350-353.

Keigwin, L.D., Jr., 1982b. Neogene planktonic foraminifers from Deep Sea Drilling Project Sites 502 and 503. In Prell, W.L., Gardner, J.V., et al., Init. Repts. DSDP, 68: Washington (U.S. Govt. Printing Office), 269-288.

Keller, G., and Barron, J.A., 1983. Paleoceanographic implications of Miocene deep-sea hiatuses. Geol. Soc. Am. Bull., 94:590-613.

Keller, G., Zenker, C.E., and Stone, S.M., 1989. Late Neogene history of the Pacific-Caribbean gateway. J. South Am. Earth Sci., 2:73-108.

Kemp, A.E.S., and Baldauf, J.G., 1993. Vast Neogene laminated diatom mat deposits from the eastern equatorial Pacific Ocean. Nature, 362:141-144.

Kennett, J.P. (Ed.), 1985. The Miocene Ocean: Paleoceanography and Biogeography. Mem.-Geol. Soc. Am., 163.

Knowlton, N., Weigt, L.A., Solorzano, L.A., Mills, D.K., and Bermingham, E., 1993. Divergence in proteins, mitochondrial DNA, and reproductive compatibility across the Isthmus of Panama. Science, 260:1629-1632.

Lange, C.B., and Berger, W.H., 1993. Diatom productivity and preservation in the western equatorial Pacific: the Quaternary record. In Berger, W.H., Kroenke, L.W., Mayer, L.A., et al., Proc. ODP, Sci. Results, 130: College Station, TX (Ocean Drilling Program), 509-523.

Leg 145 Shipboard Scientific Party, 1993. Paleoceanographic record of North Pacific quantified. Eos, 74:406-411.

Leinen, M., 1979. Biogenic silica accumulation in the central equatorial Pacific and its implications for Cenozoic paleoceanography. Geol. Soc. Am. Bull., 90:1310-1376.

Levitus, S., 1982. Climatological Atlas of the World Ocean. NOAA Prof. Pap., 13.

Lukas, R., 1986. The termination of the equatorial undercurrent in the Eastern Pacific. Prog. Oceanogr., 16:63-90.

Lundelius, E.L., Jr., 1987. The North American Quaternary sequence. In Woodburne, M.O. (Ed.), Cenozoic Mammals of North America: Berkeley (Univ. California Press), 211-235.

Lyle, M., 1992. Composition maps of surface sediments of the eastern tropical Pacific Ocean. In Mayer, L., Pisias, N., Janecek, T., et al., Proc. ODP, Init. Repts., 138 (Pt. 1): College Station, TX (Ocean Drilling Program), 101-115.

Maier-Reimer, E., Mikolajewicz, U., and Crowley, T., 1990. Ocean general circulation model sensitivity experiment with an open Central American Isthmus. Paleoceanography, 5:349-366.

Mammerickx, J., and Naur, D.F., 1988. The Mathematician paleoplate. J. Geophys. Res., 93:3025-3040.

Mann, P., and Burke, K., 1984. Neotectonics of the Caribbean. Rev. Geophys. Space Phys., 22:309-362.

Mann, P., and Corrigan, J., 1990. Model of late Neogene deformation in Panama. Geology, 18:558-562.

Marshall, L.G., 1985. Geochronology and land-mammal biochronology of the transamerican faunal interchange. In Stehli, F.G., and Webb, S.D. (Eds.), The Great American Biotic Interchange: New York (Plenum), 303-324.

, 1988. Land mammals and the Great American Interchange. Am. Sci., 76:380-388.

Mayer, L., Pisias, N., Janecek, T., et al., 1992. Proc. ODP, Init. Repts., 138 (Pts. 1 and 2): College Station, TX (Ocean Drilling Program).

Mayer, L.A., 1979. Deep sea carbonates: acoustic, physical, and stratigraphic properties. J. Sediment. Petrol., 49:819-836.

, 1991. Extraction of high-resolution carbonate data for paleoclimate reconstruction. Nature, 352:148-150.
Mayer, L.A., Shipley, T.H., and Winterer, E.L., 1986. Equatorial Pacific seismic reflectors as indicators of global oceanographic events. Science, 233:761-764.

Mikolajewicz, U., Maier-Reimer, E., Crowley, T.J., and Kim, K.-Y., 1993. Effect of Drake and Panamanian gateways on the circulation of an ocean model. Paleoceanography, 8:409-426.

Moore, T.C., Jr., Shackleton, N.J., and Pisias, N.G., 1993. Paleoceanography and the diachrony of radiolarian events in the eastern equatorial Pacific. Paleoceanography, 8:567-586.

Mortlock, R.A., and Froelich, P.N., 1989. A simple method for the rapid determination of biogenic opal in pelagic marine sediments. Deep-Sea Res. Part A, 36:1415-1426.

Mosher, D.C., Mayer, L.A., Shipley, T.H., Winterer, E.L., Hagen, R.A., Marsters, J.C., Bassinot, F., Wilkens, R.H., and Lyle, M., 1993. Seismic stratigraphy of the Ontong Java Plateau. In Berger, W.H., Kroenke, L.W. Mayer, L.A., et al., Proc. ODP, Sci. Results, 130: College Station, TX (Ocean Drilling Program), 33-49.

Peterson, L.C., Murray, D.W., Ehrmann,W.U., and Hempel, P., 1992. Cenozoic carbonate accumulation and compensation depth changes in the Indian Ocean. In Duncan, R.A., Rea, D.K., Kidd, R.B., von Rad, U.,and Weissel, J.K. (Eds.), Synthesis of Results from Scientific Drilling in the Indian Ocean. Geophys. Monogr., Am. Geophys Union, 70:311-333.

Pisias, N.G., Shackleton, N.J., and Hall, M.A., 1985. Stable isotope and calcium carbonate records from hydraulic piston cored Hole 574A: highresolution records from the middle Miocene. In Mayer, L., Theyer, F., Thomas, E., et al., Init. Repts. DSDP, 85: Washington (U.S. Govt. Printing Office), $735-748$

Prell, W.L., 1982. Oxygen and carbon isotope stratigraphy for the Quaternary of Hole 502B: evidence for two modes of isotopic variability. In Prell, W.L., Gardner, J.V., et al., Init. Repts. DSDP, 68: Washington (U.S. Govt. Printing Office), 455-464

Rio, D., Fornaciari, E., and Raffi, I., 1990. Late Oligocene through early Pleistocene calcareous nannofossils from western equatorial Indian Ocean (Leg 115). In Duncan, R.A., Backman, J., Peterson, L.C., et al., Proc. ODP, Sci. Results, 115: College Station, TX (Ocean Drilling Program), 175-235.

Roth, P.H., 1973. Calcareous nannofossils-Leg 17, Deep Sea Drilling Project. In Winterer, E.L., Ewing, J.I., et al., Init. Repts. DSDP, 17: Washington (U.S. Govt. Printing Office), 695-795.

Roth, P.H., and Thierstein, H., 1972. Calcareous nannoplankton: Leg 14 of the Deep Sea Drilling Project. In Hayes, D.E., Pimm, A.C., et al., Init. Repts. DSDP, 14: Washington (U.S. Govt. Printing Office), 421-485.

Saito, T., 1976. Geologic significance of coiling direction in the planktonic foraminifer Pulleniatina. Geology, 4:305-309.

Saito, T., Burckle, L.H., and Hays, J.D., 1975. Late Miocene to Pleistocene biostratigraphy of equatorial Pacific sediments. In Saito, T., and Burckle, L.H. (Eds.), Late Neogene Epoch Boundaries. Micropaleontology, Spec. Publ. 1:226-244.

Savin, S.M., and Douglas, R.G., 1985. Sea level, climate and the Central American land bridge. In Stehli, F.G., and Webb, S.D. (Eds.), The Great American Biotic Interchange: New York (Plenum), 303-324.

Schlich, R., Wise, S.W., Jr., et al., 1989. Proc. ODP, Init. Repts., 120: College Station, TX (Ocean Drilling Program).

Shackleton, N.J., Backman, J., Zimmerman, H., Kent, D.V., Hall, M.A., Roberts, D.G., Schnitker, D., Baldauf, J.G., Desprairies, A., Homrighausen, R., Huddlestun, P., Keene, J.B., Kaltenback, A.J., Krumsiek, K.A.O., Morton, A.C., Murray, J.W., and Westberg-Smith, J., 1984. Oxygen isotope calibration of the onset of ice-rafting and history of glaciation in the North Atlantic region. Nature, 307:620-623.

Sikes, E.L., Keigwin, L.D., and Curry, W.B., 1991. Pliocene paleoceanography circulation and oceanographic changes associated with the $2.4 \mathrm{Ma}$ glacial event. Paleoceanography, 6:245-258.

Start, G.G., and Prell, W.L., 1984. Evidence for two Pleistocene climatic modes: data from DSDP Site 502. In Berger, A.L., and Nicolis, C. (Eds.), New Perspectives in Climate Modeling: New York (Elsevier), 3-22.

Theyer, F., Mayer, L.A., Barron, J.A., and Thomas, E., 1985. The equatorial Pacific high-productivity belt: elements for a synthesis of Deep Sea Drilling Project Leg 85 results. In Mayer, L., Theyer, F., Thomas, E., et al., Init. Repts. DSDP, 85: Washington (U.S. Govt. Printing Office), 971-985.

Theyer, F., Vincent, E., and Mayer, L.A., 1989. Sedimentation and paleoceanography of the central equatorial Pacific. In Winterer, E.L., Hussong, D.M., and Decker, R.W. (Eds.), The Eastern Pacific Ocean and Hawaii. Geology of North America, Geol. Soc. Am., N:347-372. 
Toggweiler, J.R., Dixon, K., and Broecker, W.S., 1991. The Peru upwelling and the ventilation of the south Pacific thermocline. J. Geophys. Res., 96:20467-20497.

van Andel, T.H., Heath, G.R., and Moore, T.C., Jr., 1975. Cenozoic history and paleoceanography of the central equatorial Pacific Ocean: a regional synthesis of Deep Sea Drilling Project data. Mem.-Geol. Soc. Am., 143.

Vincent, E., 1981. Neogene carbonate stratigraphy of Hess Rise (central North Pacific) and paleoceanographic implications. In Thiede, J., Vallier, T.L., et al., Init. Repts. DSDP, 62: Washington (U.S. Govt. Printing Office), 571-606.

Wadge, G., and Burke, K., 1983. Neogene Caribbean Plate rotation and associated Central American tectonic evolution. Tectonics, 2:633-643.

Webb, S.D., 1985. Late Cenozoic mammal dispersals between the Americas. In Stehli, F.G., and Webb, S.D. (Eds.), The Great American Biotic Interchange: New York (Plenum), 357-386.

Weinreich, N., and Theyer, F., 1985. Paleomagnetism of Deep Sea Drilling Project Leg 85 sediments: Neogene magnetostratigraphy and tectonic history of the central Equatorial Pacific. In Mayer, L., Theyer, F., Thomas, E., et al., Init. Repts. DSDP, 85: Washington (U.S. Govt. Printing Office), 849-901.

Woodruff, F., Savin, S.M., and Douglas, R.G., 1981. Miocene stable isotope record: a detailed deep Pacific Ocean study and its paleoclimatic implications. Science, 212:665-668.
Wooster, W.S., and Gilmartin, M., 1961. The Peru-Chile Undercurrent. J. Mar. Res., 19:97-122.

Wright, J.D., Miller, K.G., and Fairbanks, R.G., 1991. Evolution of modern deepwater circulation: evidence from the late Miocene Southern Ocean. Paleoceanography, 6:275-290.

1992. Early and middle Miocene stable isotopes: implications for deepwater circulation and climate. Paleoceanography, 7:357-389.

Wyrtki, K., 1967. Circulation and water masses in the eastern equatorial Pacific Ocean. Int. J. Oceanol. Limnol., 1:117-147.

Wyrtki, K., and Kilonsky, B., 1984. Mean water and current structure during the Hawaii-to-Tahiti shuttle experiment. J. Phys. Oceanogr., 14:242-254.

Xie, L., and Hsieh, W.W., in press. The global distribution of wind-induced upwelling. Fish Oceanogr.

Date of initial receipt: 22 November 1993

Date of acceptance: 5 July 1994

Ms 138SR-143 
APPENDIX A

Leg 138 Percentages of $\mathrm{CaCO}_{3}$ and Associated Data

\begin{tabular}{|c|c|c|c|c|c|c|c|}
\hline Hole & $\begin{array}{l}\text { Depth } \\
\text { (mcd) }\end{array}$ & $\begin{array}{l}\text { Age } \\
(\mathrm{Ma})\end{array}$ & $\begin{array}{c}\text { LSR } \\
(\mathrm{cm} / \mathrm{k}, \mathrm{y} .)\end{array}$ & $\begin{array}{c}\text { DBD } \\
\left(\mathrm{g} / \mathrm{cm}^{3}\right)\end{array}$ & $\begin{array}{c}\mathrm{CaCO}_{3} \\
(\%)\end{array}$ & $\begin{array}{l}\mathrm{CaCO}_{3} \\
\mathrm{MAR}^{3}\end{array}$ & Source \\
\hline $844 B$ & 1.69 & 0.145 & 1.36 & 0.347 & 15.40 & 0.07 & Levitan \\
\hline $844 \mathrm{~A}$ & 1.79 & 0.152 & 1.39 & 0.302 & 0.42 & 0.00 & Shipboard \\
\hline $844 \mathrm{~B}$ & 1.79 & 0.152 & 1.39 & 0.301 & 0.00 & 0.00 & Shipboard \\
\hline $844 \mathrm{~A}$ & 2.11 & 0.175 & 1.67 & 0.307 & 2.13 & 0.01 & Shipboard \\
\hline $844 \mathrm{~B}$ & 2.98 & 0.227 & 1.49 & 0.311 & 3.58 & 0.02 & Shipboard \\
\hline $844 B$ & 3.26 & 0.246 & 1.10 & 0.317 & 5.58 & 0.02 & Shipboard \\
\hline $844 \mathrm{~A}$ & 3.32 & 0.252 & 1.05 & 0.314 & 4.42 & 0.01 & Shipboard \\
\hline $844 \mathrm{~A}$ & 3.84 & 0.301 & 1.05 & 0.314 & 4.67 & 0.02 & Shipboard \\
\hline $844 \mathrm{~B}$ & 4.01 & 0.318 & 1.31 & 0.310 & 3.25 & 0.01 & Shipboard \\
\hline $844 \mathrm{~A}$ & 4.89 & 0.385 & 1.65 & 0.315 & 5.04 & 0.03 & Shipboard \\
\hline $844 \mathrm{~A}$ & 5.35 & 0.413 & 1.63 & 0.308 & 2.50 & 0.01 & Shipboard \\
\hline $844 \mathrm{~B}$ & 5.95 & 0.450 & 1.58 & 0.315 & 4.92 & 0.02 & Shipboard \\
\hline $844 B$ & 6.10 & 0.459 & 1.77 & 0.362 & 19.54 & 0.12 & Shipboard \\
\hline $844 \mathrm{~A}$ & 6.16 & 0.462 & 1.35 & 0.307 & 2.17 & 0.01 & Shipboard \\
\hline $844 \mathrm{~A}$ & 6.94 & 0.520 & 1.39 & 0.325 & 8.33 & 0.04 & Shipboard \\
\hline $844 \mathrm{~B}$ & 7.60 & 0.568 & 1.40 & 0.313 & 4.33 & 0.02 & Shipboard \\
\hline $844 \mathrm{~A}$ & 7.76 & 0.579 & 1.52 & 0.308 & 2.50 & 0.01 & Shipboard \\
\hline $844 \mathrm{~A}$ & 8.50 & 0.628 & 0.94 & 0.311 & 3.42 & 0.01 & Shipboard \\
\hline $844 \mathrm{~B}$ & 8.91 & 0.672 & 0.97 & 0.351 & 16.50 & 0.06 & Shipboard \\
\hline $844 \mathrm{~A}$ & 9.43 & 0.725 & 1.14 & 0.317 & 5.67 & 0.02 & Shipboard \\
\hline $844 \mathrm{~A}$ & 10.08 & 0.782 & 0.85 & 0.320 & 6.50 & 0.02 & Shipboard \\
\hline $844 \mathrm{~B}$ & 10.38 & 0.818 & 0.82 & 0.369 & 21.42 & 0.06 & Shipboard \\
\hline $844 \mathrm{~B}$ & 10.59 & 0.842 & 1.26 & 0.375 & 23.00 & 0.11 & Shipboard \\
\hline $844 \mathrm{~A}$ & 10.60 & 0.844 & 0.83 & 0.398 & 28.59 & 0.09 & Shipboard \\
\hline $844 \mathrm{~A}$ & 11.04 & 0.896 & 0.88 & 0.312 & 3.83 & 0.01 & Shipboard \\
\hline $844 \mathrm{~B}$ & 11.14 & 0.908 & 0.87 & 0.311 & 3.50 & 0.01 & Shipboard \\
\hline $844 \mathrm{~B}$ & 11.99 & 1.006 & 0.95 & 0.323 & 7.83 & 0.02 & Shipboard \\
\hline $844 B$ & 12.09 & 1.016 & 1.00 & 0.335 & 11.50 & 0.04 & Shipboard \\
\hline $844 B$ & 12.65 & 1.073 & 0.78 & 0.354 & 17.50 & 0.05 & Shipboard \\
\hline $844 \mathrm{~B}$ & 13.45 & 1.175 & 0.75 & 0.381 & 24.59 & 0.07 & Shipboard \\
\hline $844 \mathrm{~B}$ & 13.58 & 1.192 & 0.79 & 0.319 & 6.17 & 0.02 & Shipboard \\
\hline $844 B$ & 14.13 & 1.262 & 0.78 & 0.324 & 7.92 & 0.02 & Shipboard \\
\hline $844 B$ & 14.89 & 1.359 & 0.78 & 0.318 & 5.83 & 0.01 & Shipboard \\
\hline $844 \mathrm{~B}$ & 16.92 & 1.619 & 0.78 & 0.302 & 0.42 & 0.00 & Shipboard \\
\hline $844 \mathrm{~B}$ & 17.02 & 1.632 & 0.73 & 0.334 & 11.17 & 0.03 & Shipboard \\
\hline $844 \mathrm{~B}$ & 18.42 & 1.825 & 0.58 & 0.306 & 1.67 & 0.00 & Shipboard \\
\hline $844 B$ & 18.52 & 1.842 & 0.60 & 0.302 & 0.33 & 0.00 & Shipboard \\
\hline $844 B$ & 18.76 & 1.883 & 0.52 & 0.302 & 0.08 & 0.00 & Shipboard \\
\hline $844 \mathrm{~B}$ & 19.56 & 2.037 & 0.44 & 0.302 & 0.08 & 0.00 & Shipboard \\
\hline $844 \mathrm{~B}$ & 19.63 & 2.052 & 0.47 & 0.301 & 0.00 & 0.00 & Levitan \\
\hline $844 B$ & 19.92 & 2.114 & 0.47 & 0.306 & 1.83 & 0.00 & Shipboard \\
\hline $844 \mathrm{~B}$ & 20.02 & 2.135 & 0.48 & 0.307 & 2.17 & 0.00 & Shipboard \\
\hline $844 \mathrm{~B}$ & 20.26 & 2.187 & 0.47 & 0.331 & 10.25 & 0.02 & Shipboard \\
\hline $844 B$ & 20.93 & 2.329 & 0.48 & 0.323 & 7.70 & 0.01 & Levitan \\
\hline $844 \mathrm{~B}$ & 21.12 & 2.370 & 0.46 & 0.316 & 5.42 & 0.01 & Shipboard \\
\hline $844 B$ & 21.42 & 2.434 & 0.47 & 0.351 & 16.67 & 0.03 & Shipboard \\
\hline $844 B$ & 21.52 & 2.455 & 0.48 & 0.374 & 22.75 & 0.04 & Shipboard \\
\hline $844 B$ & 21.77 & 2.508 & 0.47 & 0.350 & 16.33 & 0.03 & Shipboard \\
\hline $844 \mathrm{~B}$ & 21.96 & 2.549 & 0.38 & 0.316 & 5.17 & 0.01 & Shipboard \\
\hline $844 B$ & 22.56 & 2.705 & 0.32 & 0.302 & 0.42 & 0.00 & Shipboard \\
\hline $844 B$ & 22.64 & 2.729 & 0.34 & 0.302 & 0.17 & 0.00 & Shipboard \\
\hline $844 B$ & 23.02 & 2.840 & 0.35 & 0.305 & 1.42 & 0.00 & Shipboard \\
\hline $844 \mathrm{~B}$ & 23.27 & 2.913 & 0.31 & 0.320 & 6.63 & 0.01 & Shipboard \\
\hline $844 B$ & 23.95 & 3.131 & 0.51 & 0.303 & 0.50 & 0.00 & Shipboard \\
\hline $844 B$ & 24.06 & 3.154 & 0.46 & 0.302 & 0.42 & 0.00 & Shipboard \\
\hline $844 B$ & 24.15 & 3.172 & 0.22 & 0.303 & 0.46 & 0.00 & Shipboard \\
\hline $844 B$ & 24.52 & 3.343 & 0.35 & 0.305 & 1.17 & 0.00 & Shipboard \\
\hline $844 B$ & 24.97 & 3.473 & 0.34 & 0.399 & 28.75 & 0.04 & Shipboard \\
\hline $844 B$ & 25.23 & 3.548 & 0.32 & 0.311 & 3.33 & 0.00 & Shipboard \\
\hline $844 B$ & 25.56 & 3.654 & 0.24 & 0.303 & 0.58 & 0.00 & Shipboard \\
\hline $844 B$ & 25.65 & 3.688 & 0.31 & 0.304 & 0.83 & 0.00 & Shipboard \\
\hline $844 \mathrm{D}$ & 29.46 & 4.899 & 0.55 & 0.331 & 10.42 & 0.02 & Shipboard \\
\hline $844 \mathrm{D}$ & 30.96 & 5.171 & 0.58 & 0.352 & 16.83 & 0.03 & Shipboard \\
\hline 844D & 32.46 & 5.428 & 0.59 & 0.358 & 18.67 & 0.04 & Shipboard \\
\hline $844 \mathrm{D}$ & 33.96 & 5.682 & 0.62 & 0.382 & 24.75 & 0.06 & Shipboard \\
\hline $844 \mathrm{D}$ & 35.46 & 5.926 & 0.71 & 0.531 & 50.84 & 0.19 & Shipboard \\
\hline $844 \mathrm{D}$ & 36.96 & 6.137 & 0.75 & 0.455 & 39.59 & 0.13 & Shipboard \\
\hline $844 \mathrm{~B}$ & 37.31 & 6.184 & 0.76 & 0.504 & 47.09 & 0.18 & Shipboard \\
\hline $844 B$ & 37.66 & 6.231 & 0.34 & 0.366 & 20.75 & 0.03 & Shipboard \\
\hline $844 \mathrm{~B}$ & 38.33 & 6.424 & 0.29 & 0.384 & 25.30 & 0.03 & Levitan \\
\hline 844D & 38.46 & 6.470 & 0.34 & 0.393 & 27.50 & 0.04 & Shipboard \\
\hline $844 B$ & 38.81 & 6.571 & 0.63 & 0.336 & 12.00 & 0.03 & Shipboard \\
\hline $844 B$ & 40.31 & 6.810 & 0.57 & 0.516 & 48.84 & 0.14 & Shipboard \\
\hline $844 B$ & 41.81 & 7.074 & 0.43 & 0.366 & 20.75 & 0.03 & Shipboard \\
\hline $844 B$ & 43.31 & 7.422 & 0.98 & 0.350 & 16.33 & 0.06 & Shipboard \\
\hline $844 B$ & 43.85 & 7.477 & 1.01 & 0.555 & 53.75 & 0.30 & Shipboard \\
\hline $844 \mathrm{C}$ & 44.08 & 7.500 & 0.98 & 0.374 & 22.92 & 0.08 & Shipboard \\
\hline $844 B$ & 44.36 & 7.529 & 0.66 & 0.385 & 25.42 & 0.06 & Shipboard \\
\hline $844 B$ & 44.81 & 7.596 & 0.94 & 0.351 & 16.58 & 0.05 & Shipboard \\
\hline $844 \mathrm{C}$ & 45.20 & 7.638 & 1.21 & 0.311 & 3.42 & 0.01 & Shipboard \\
\hline $844 B$ & 45.63 & 7.674 & 1.22 & 0.312 & 3.92 & 0.01 & Shipboard \\
\hline $844 B$ & 46.31 & 7.729 & 1.24 & 0.460 & 40.38 & 0.23 & Shipboard \\
\hline $844 \mathrm{C}$ & 46.68 & 7.760 & 1.21 & 0.354 & 17.50 & 0.08 & Shipboard \\
\hline $844 B$ & 47.25 & 7.806 & 1.23 & 0.768 & 74.17 & 0.70 & Shipboard \\
\hline $844 \mathrm{C}$ & 48.11 & 7.876 & 1.21 & 0.595 & 58.34 & 0.42 & Shipboard \\
\hline $844 B$ & 48.89 & 7.940 & 1.23 & 0.584 & 57.17 & 0.41 & Shipboard \\
\hline
\end{tabular}

Only the first page of this table is reproduced here. The entire table appears on the CD-ROM (back pocket). 
APPENDIX B

Leg 138 Opal and Associated Data

\begin{tabular}{|c|c|c|c|c|c|c|c|c|c|c|c|}
\hline Hole & $\begin{array}{l}\text { Depth } \\
\text { (mcd) }\end{array}$ & $\begin{array}{l}\text { Age } \\
\text { (Ma) }\end{array}$ & $\begin{array}{c}\text { LSR } \\
\text { (cm/k.y.) }\end{array}$ & $\begin{array}{c}\text { DBD } \\
\left(\mathrm{g} / \mathrm{cm}^{3}\right)\end{array}$ & $\begin{array}{c}\mathrm{CaCO}_{3} \\
(\%)\end{array}$ & $\begin{array}{l}\text { Opal } \\
(\%)\end{array}$ & $\begin{array}{l}\text { Terrig. } \\
(\%)\end{array}$ & $\begin{array}{l}\mathrm{CaCO}_{3} \\
\mathrm{MAR}\end{array}$ & $\begin{array}{l}\text { Opal } \\
\text { MAR }\end{array}$ & $\begin{array}{l}\text { Terrig. } \\
\text { MAR }\end{array}$ & $\begin{array}{l}\text { Opal } \\
\text { source }\end{array}$ \\
\hline $844 B$ & 1.69 & 0.145 & 1.36 & 0.347 & 15.40 & 14.40 & 70.20 & 0.07 & 0.07 & 0.33 & Levitan \\
\hline $844 \mathrm{~B}$ & 1.79 & 0.152 & 1.56 & 0.301 & 0.00 & 17.35 & 82.65 & 0.00 & 0.08 & 0.39 & Janecek \\
\hline $844 \mathrm{~B}$ & 3.26 & 0.246 & 1.32 & 0.317 & 5.58 & 17.02 & 77.40 & 0.02 & 0.07 & 0.32 & Janecek \\
\hline $844 \mathrm{~B}$ & 5.95 & 0.450 & 1.39 & 0.315 & 4.92 & 15.17 & 79.91 & 0.02 & 0.07 & 0.35 & Janecek \\
\hline $844 \mathrm{~B}$ & 7.60 & 0.568 & 1.27 & 0.313 & 4.33 & 18.00 & 77.67 & 0.02 & 0.07 & 0.31 & Janecek \\
\hline $844 B$ & 8.91 & 0.672 & 0.98 & 0.351 & 16.50 & 15.29 & 68.21 & 0.06 & 0.05 & 0.23 & Janecek \\
\hline $844 \mathrm{~B}$ & 10.59 & 0.842 & 0.86 & 0.375 & 23.00 & 14.06 & 62.93 & 0.07 & 0.05 & 0.20 & Janecek \\
\hline $844 B$ & 12.09 & 1.016 & 0.86 & 0.335 & 11.50 & 15.31 & 73.19 & 0.03 & 0.04 & 0.21 & Janecek \\
\hline $844 \mathrm{~B}$ & 13.45 & 1.175 & 0.78 & 0.381 & 24.59 & 10.92 & 64.49 & 0.07 & 0.03 & 0.19 & Janecek \\
\hline $844 \mathrm{~B}$ & 14.89 & 1.359 & 0.78 & 0.318 & 5.83 & 11.38 & 82.79 & 0.01 & 0.03 & 0.21 & Janecek \\
\hline $844 \mathrm{~B}$ & 17.02 & 1.632 & 0.73 & 0.334 & 11.17 & 14.52 & 74.31 & 0.03 & 0.04 & 0.18 & Janecek \\
\hline $844 \mathrm{~B}$ & 18.42 & 1.825 & 0.58 & 0.306 & 1.67 & 13.27 & 85.06 & 0.00 & 0.02 & 0.15 & Janecek \\
\hline $844 \mathrm{~B}$ & 18.52 & 1.842 & 0.53 & 0.302 & 0.33 & 16.68 & 82.99 & 0.00 & 0.03 & 0.13 & Janecek \\
\hline $844 \mathrm{~B}$ & 19.56 & 2.037 & 0.44 & 0.302 & 0.08 & 8.45 & 91.47 & 0.00 & 0.01 & 0.12 & Janecek \\
\hline $844 \mathrm{~B}$ & 19.63 & 2.052 & 0.47 & 0.301 & 0.00 & 8.40 & 91.60 & 0.00 & 0.01 & 0.13 & Levitan \\
\hline $844 B$ & 19.92 & 2.114 & 0.47 & 0.306 & 1.83 & 13.63 & 84.53 & 0.00 & 0.02 & 0.12 & Janecek \\
\hline $844 \mathrm{~B}$ & 20.02 & 2.135 & 0.47 & 0.307 & 2.17 & 13.63 & 84.20 & 0.00 & 0.02 & 0.12 & Janecek \\
\hline $844 \mathrm{~B}$ & 20.93 & 2.329 & 0.48 & 0.323 & 7.70 & 6.70 & 85.60 & 0.01 & 0.01 & 0.13 & Levitan \\
\hline $844 B$ & 21.12 & 2.370 & 0.46 & 0.316 & 5.42 & 10.63 & 83.95 & 0.01 & 0.02 & 0.12 & Janecek \\
\hline $844 \mathrm{~B}$ & 21.52 & 2.455 & 0.42 & 0.374 & 22.75 & 10.30 & 66.95 & 0.04 & 0.02 & 0.10 & Janecek \\
\hline $844 \mathrm{~B}$ & 22.56 & 2.705 & 0.34 & 0.302 & 0.42 & 11.57 & 88.02 & 0.00 & 0.01 & 0.09 & Janecek \\
\hline 844B & 23.02 & 2.840 & 0.33 & 0.305 & 1.42 & 10.97 & 87.62 & 0.00 & 0.01 & 0.09 & Janecek \\
\hline $844 B$ & 24.06 & 3.154 & 0.24 & 0.302 & 0.42 & 12.74 & 86.84 & 0.00 & 0.01 & 0.06 & Janecek \\
\hline $844 B$ & 24.52 & 3.343 & 0.34 & 0.305 & 1.17 & 6.12 & 92.71 & 0.00 & 0.01 & 0.09 & Janecek \\
\hline $844 \mathrm{~B}$ & 25.56 & 3.654 & 0.46 & 0.303 & 0.58 & 9.79 & 89.62 & 0.00 & 0.01 & 0.13 & Janecek \\
\hline $844 B$ & 37.31 & 6.184 & 0.42 & 0.504 & 47.09 & 14.59 & 38.32 & 0.10 & 0.03 & 0.08 & Janecek \\
\hline $844 \mathrm{~B}$ & 38.33 & 6.424 & 0.33 & 0.384 & 25.30 & 11.38 & 63.32 & 0.03 & 0.01 & 0.08 & Levitan \\
\hline $844 \mathrm{~B}$ & 38.81 & 6.571 & 0.63 & 0.336 & 12.00 & 18.53 & 69.47 & 0.03 & 0.04 & 0.15 & Janecek \\
\hline $844 B$ & 40.31 & 6.810 & 0.57 & 0.516 & 48.84 & 12.89 & 38.27 & 0.14 & 0.04 & 0.11 & Janecek \\
\hline $844 \mathrm{~B}$ & 41.81 & 7.074 & 0.51 & 0.366 & 20.75 & 18.74 & 60.50 & 0.04 & 0.03 & 0.11 & Janecek \\
\hline $844 B$ & 43.85 & 7.477 & 0.98 & 0.555 & 53.75 & 25.80 & 20.45 & 0.29 & 0.14 & 0.11 & Janecek \\
\hline $844 \mathrm{~B}$ & 46.31 & 7.729 & 1.22 & 0.460 & 40.38 & 21.19 & 38.43 & 0.23 & 0.12 & 0.22 & Janecek \\
\hline $844 B$ & 47.25 & 7.806 & 1.22 & 0.768 & 74.17 & 7.99 & 17.84 & 0.70 & 0.08 & 0.17 & Janecek \\
\hline 844B & 48.89 & 7.940 & 1.00 & 0.584 & 57.17 & 11.81 & 31.02 & 0.33 & 0.07 & 0.18 & Janecek \\
\hline $844 B$ & 50.28 & 8.080 & 0.63 & 0.555 & 53.75 & 15.72 & 30.53 & 0.19 & 0.05 & 0.11 & Janecek \\
\hline $844 B$ & 51.30 & 8.243 & 0.62 & 0.601 & 59.00 & 6.38 & 34.62 & 0.22 & 0.02 & 0.13 & Levitan \\
\hline $844 \mathrm{~B}$ & 51.79 & 8.322 & 0.62 & 0.692 & 67.84 & 9.17 & 22.99 & 0.29 & 0.04 & 0.10 & Janecek \\
\hline $844 B$ & 53.29 & 8.562 & 0.83 & 0.324 & 7.92 & 27.60 & 64.48 & 0.02 & 0.07 & 0.17 & Janecek \\
\hline 844B & 54.79 & 8.742 & 0.96 & 0.417 & 32.59 & 24.02 & 43.39 & 0.13 & 0.10 & 0.17 & Janecek \\
\hline $844 \mathrm{~B}$ & 56.29 & 8.897 & 0.78 & 0.305 & 1.25 & 26.09 & 72.66 & 0.00 & 0.06 & 0.17 & Janecek \\
\hline $844 B$ & 59.41 & 9.297 & 0.75 & 0.333 & 10.92 & 25.30 & 63.79 & 0.03 & 0.06 & 0.16 & Janecek \\
\hline $844 B$ & 60.91 & 9.496 & 1.04 & 0.302 & 0.25 & 31.63 & 68.12 & 0.00 & 0.10 & 0.21 & Janecek \\
\hline $844 B$ & 62.41 & 9.640 & 1.23 & 0.303 & 0.58 & 11.90 & 87.51 & 0.00 & 0.04 & 0.33 & Janecek \\
\hline 844B & 63.91 & 9.761 & 1.24 & 0.302 & 0.35 & 31.01 & 68.64 & 0.00 & 0.12 & 0.26 & Janecek \\
\hline $844 \mathrm{~B}$ & 64.87 & 9.839 & 1.23 & 0.311 & 3.50 & 18.52 & 77.98 & 0.01 & 0.07 & 0.30 & Levitan \\
\hline $844 B$ & 65.41 & 9.883 & 1.23 & 0.452 & 39.00 & 19.97 & 41.03 & 0.22 & 0.11 & 0.23 & Janecek \\
\hline 844B & 66.91 & 10.004 & 1.13 & 0.562 & 54.67 & 14.64 & 30.69 & 0.35 & 0.09 & 0.20 & Janecek \\
\hline $844 B$ & 68.41 & 10.137 & 1.12 & 0.586 & 57.42 & 14.86 & 27.72 & 0.38 & 0.10 & 0.18 & Janecek \\
\hline 844B & 70.11 & 10.289 & 1.12 & 0.444 & 37.67 & 21.82 & 40.51 & 0.19 & 0.11 & 0.20 & Janecek \\
\hline $844 B$ & 71.61 & 10.423 & 1.18 & 0.449 & 38.50 & 15.29 & 46.21 & 0.20 & 0.08 & 0.24 & Janecek \\
\hline $844 \mathrm{~B}$ & 73.33 & 10.569 & 1.61 & 0.804 & 76.90 & 6.18 & 16.92 & 0.99 & 0.08 & 0.22 & Levitan \\
\hline 844B & 73.46 & 10.577 & 1.71 & 0.728 & 70.92 & 10.01 & 19.07 & 0.88 & 0.12 & 0.24 & Janecek \\
\hline $844 \mathrm{~B}$ & 76.11 & 10.732 & 2.17 & 0.709 & 69.34 & 15.89 & 14.77 & 1.07 & 0.24 & 0.23 & Janecek \\
\hline 844B & 77.61 & 10.801 & 2.17 & 0.400 & 28.92 & 38.76 & 32.32 & 0.25 & 0.34 & 0.28 & Janecek \\
\hline $844 \mathrm{~B}$ & 80.32 & 10.926 & 2.21 & 0.396 & 28.09 & 43.39 & 28.52 & 0.25 & 0.38 & 0.25 & Janecek \\
\hline 844B & 81.82 & 10.994 & 3.12 & 0.607 & 59.67 & 18.14 & 22.18 & 1.13 & 0.34 & 0.42 & Janecek \\
\hline $844 B$ & 83.32 & 11.042 & 3.12 & 0.508 & 47.67 & 21.82 & 30.51 & 0.75 & 0.35 & 0.48 & Janecek \\
\hline $844 B$ & 84.32 & 11.074 & 3.13 & 0.646 & 63.60 & 9.28 & 27.12 & 1.28 & 0.19 & 0.55 & Levitan \\
\hline 844B & 84.82 & 11.090 & 3.12 & 0.761 & 73.59 & 11.50 & 14.91 & 1.75 & 0.27 & 0.35 & Janecek \\
\hline $844 B$ & 86.32 & 11.138 & 3.12 & 0.764 & 73.84 & 10.78 & 15.38 & 1.76 & 0.26 & 0.37 & Janecek \\
\hline $844 \mathrm{~B}$ & 87.82 & 11.186 & 3.13 & 0.940 & 86.09 & 6.07 & 7.84 & 2.54 & 0.18 & 0.23 & Janecek \\
\hline $844 B$ & 88.98 & 11.223 & 3.11 & 0.965 & 87.59 & 5.42 & 6.99 & 2.63 & 0.16 & 0.21 & Janecek \\
\hline $844 B$ & 91.84 & 11.315 & 3.11 & 0.955 & 87.01 & 5.74 & 7.26 & 2.59 & 0.17 & 0.22 & Janecek \\
\hline $844 \mathrm{~B}$ & 93.34 & 11.363 & 3.61 & 0.930 & 85.42 & 6.41 & 8.17 & 2.86 & 0.21 & 0.27 & Janecek \\
\hline $844 B$ & 94.84 & 11.405 & 3.76 & 0.876 & 81.92 & 8.14 & 9.94 & 2.70 & 0.27 & 0.33 & Janecek \\
\hline $844 B$ & 95.81 & 11.431 & 3.76 & 0.868 & 81.40 & 7.40 & 11.20 & 2.66 & 0.24 & 0.37 & Levitan \\
\hline $844 \mathrm{~B}$ & 96.34 & 11.445 & 3.76 & 0.909 & 84.09 & 6.96 & 8.95 & 2.87 & 0.24 & 0.31 & Janecek \\
\hline $844 B$ & 97.84 & 11.485 & 3.76 & 0.946 & 86.42 & 6.79 & 6.78 & 3.07 & 0.24 & 0.24 & Janecek \\
\hline $844 \mathrm{~B}$ & 99.34 & 11.524 & 3.76 & 0.836 & 79.17 & 10.08 & 10.75 & 2.49 & 0.32 & 0.34 & Janecek \\
\hline $844 \mathrm{~B}$ & 104.21 & 11.654 & 3.76 & 0.815 & 77.67 & 9.31 & 13.02 & 2.38 & 0.29 & 0.40 & Janecek \\
\hline $844 \mathrm{~B}$ & 105.71 & 11.694 & 3.76 & 0.886 & 82.59 & 5.86 & 11.55 & 2.75 & 0.19 & 0.38 & Janecek \\
\hline $844 B$ & 107.21 & 11.734 & 3.76 & 0.761 & 73.59 & 14.90 & 11.51 & 2.10 & 0.43 & 0.33 & Janecek \\
\hline $844 B$ & 108.18 & 11.760 & 3.76 & 0.601 & 59.00 & 8.52 & 32.48 & 1.33 & 0.19 & 0.73 & Levitan \\
\hline $844 \mathrm{~B}$ & 108.71 & 11.774 & 3.76 & 0.714 & 69.76 & 17.71 & 12.53 & 1.87 & 0.48 & 0.34 & Janecek \\
\hline $844 B$ & 110.21 & 11.814 & 3.76 & 0.893 & 83.09 & 9.36 & 7.55 & 2.79 & 0.31 & 0.25 & Janecek \\
\hline $844 B$ & 111.71 & 11.853 & 3.76 & 0.855 & 80.51 & 9.31 & 10.18 & 2.59 & 0.30 & 0.33 & Janecek \\
\hline $844 B$ & 113.21 & 11.893 & 3.75 & 0.770 & 74.34 & 14.90 & 10.76 & 2.15 & 0.43 & 0.31 & Janecek \\
\hline $844 \mathrm{~B}$ & 113.69 & 11,906 & 3.76 & 0.709 & 69.34 & 14.88 & 15.78 & 1.85 & 0.40 & 0.42 & Janecek \\
\hline $844 B$ & 114.71 & 11.933 & 3.75 & 0.742 & 72.10 & 13.24 & 14.66 & 2.01 & 0.37 & 0.41 & Levitan \\
\hline $844 B$ & 115.19 & 11.946 & 3.21 & 0.849 & 80.09 & 11.14 & 8.77 & 2.18 & 0.30 & 0.24 & Janecek \\
\hline $844 B$ & 118.19 & 12.039 & 2.77 & 0.860 & 80.84 & 10.44 & 8.72 & 1.92 & 0.25 & 0.21 & Janecek \\
\hline $844 B$ & 119.69 & 12.094 & 2.76 & 0.947 & 86.51 & 8.04 & 5.45 & 2.26 & 0.21 & 0.14 & Janecek \\
\hline $844 B$ & 121.19 & 12.148 & 2.76 & 0.581 & 56.84 & 18.58 & 24.59 & 0.91 & 0.30 & 0.39 & Janecek \\
\hline $844 B$ & 122.69 & 12.202 & 2.76 & 0.382 & 24.84 & 33.62 & 41.54 & 0.26 & 0.35 & 0.44 & Janecek \\
\hline $844 \mathrm{~B}$ & 124.48 & 12.267 & 2.77 & 0.544 & 52.40 & 7.70 & 39.90 & 0.79 & 0.12 & 0.60 & Levitan \\
\hline $844 B$ & 128.31 & 12.406 & 3.19 & 0.917 & 84.59 & 7.37 & 8.04 & 2.48 & 0.22 & 0.24 & Janecek \\
\hline
\end{tabular}

Only the first page of this table is reproduced here. The entire table appears on the CD-ROM (back pocket). 
APPENDIX C

Leg 138 Nannofossil Assemblage Characterization Data

\begin{tabular}{|c|c|c|c|c|c|c|}
\hline Hole & $\begin{array}{l}\text { Depth } \\
\text { (mcd) }\end{array}$ & $\begin{array}{l}\text { Age } \\
\text { (Ma) }\end{array}$ & Abundance & Preservation & Etching & Overgrowth \\
\hline $844 B$ & 4.53 & 0.363 & 4 & 4 & I & 0 \\
\hline $844 \mathrm{C}$ & 9.60 & 0.737 & I & 2 & 2 & 0 \\
\hline $844 B$ & 15.61 & 1.451 & 3 & 4 & 1 & 0 \\
\hline $844 \mathrm{~B}$ & 18.35 & 1.813 & 2 & 3 & i & 0 \\
\hline $844 \mathrm{C}$ & 19.92 & 2.114 & i & 1 & 3 & 0 \\
\hline $844 \mathrm{~B}$ & 20.10 & 2.152 & 2 & 3 & 1 & 0 \\
\hline $844 \mathrm{~B}$ & 21.35 & 2.419 & $i$ & 2 & 2 & 0 \\
\hline $844 \mathrm{C}$ & 21.78 & 2.510 & I & I & 3 & 0 \\
\hline $844 B$ & 22.85 & 2.790 & 0 & 0 & 4 & 0 \\
\hline $844 \mathrm{C}$ & 23.28 & 2.916 & I & 1 & 3 & 0 \\
\hline $844 \mathrm{C}$ & 24.78 & 3.418 & 3 & 2 & 2 & I \\
\hline $844 \mathrm{C}$ & 25.05 & 3.496 & i & $i$ & 3 & i \\
\hline $844 \mathrm{C}$ & 25.31 & 3.571 & 0 & 0 & 4 & 0 \\
\hline $844 \mathrm{C}$ & 25.56 & 3.654 & 0 & 0 & 4 & 0 \\
\hline $844 \mathrm{C}$ & 25.95 & 3.805 & 0 & 0 & 4 & 0 \\
\hline $844 \mathrm{~B}$ & 26.30 & 3.940 & 0 & 0 & 0 & 0 \\
\hline $844 \mathrm{C}$ & 26.75 & 4.115 & 0 & 0 & 4 & 0 \\
\hline $844 \mathrm{C}$ & 27.21 & 4.267 & i & 1 & 3 & 0 \\
\hline $844 \mathrm{C}$ & 27.95 & 4.491 & i & 1 & 3 & 0 \\
\hline $844 \mathrm{C}$ & 33.00 & 5.520 & 3 & 3 & $i$ & I \\
\hline $844 \mathrm{C}$ & 34.72 & 5.811 & 3 & 3 & 1 & I \\
\hline $844 \mathrm{C}$ & 36.03 & 6.006 & 3 & 3 & i & i \\
\hline $844 \mathrm{C}$ & 36.92 & 6.131 & 3 & 3 & 1 & I \\
\hline $844 \mathrm{C}$ & 38.75 & 6.562 & 2 & 2 & 2 & i \\
\hline $844 \mathrm{~B}$ & 40,25 & 6.800 & 4 & 3 & I & 0 \\
\hline $844 \mathrm{~B}$ & 41.75 & 7.062 & 4 & 3 & I & 0 \\
\hline $844 \mathrm{~B}$ & 43.25 & 7.416 & 4 & 4 & 0 & 0 \\
\hline $844 \mathrm{C}$ & 43.60 & 7.452 & 4 & 3 & 1 & 1 \\
\hline $844 \mathrm{~B}$ & 44.75 & 7.587 & 4 & 3 & i & 0 \\
\hline $844 \mathrm{~B}$ & 46.55 & 7.749 & 4 & 3 & 1 & 1 \\
\hline $844 B$ & 48.70 & 7.925 & 4 & 4 & I & 0 \\
\hline $844 B$ & 50.20 & 8.067 & 4 & 4 & I & 0 \\
\hline $844 \mathrm{~B}$ & 51.77 & 8.319 & 4 & 4 & I & 0 \\
\hline $844 \mathrm{C}$ & 51.83 & 8.328 & 3 & 3 & i & 1 \\
\hline $844 \mathrm{~B}$ & 53.20 & 8.548 & 2 & 1 & 3 & 1 \\
\hline $844 \mathrm{~B}$ & 54.70 & 8.733 & 4 & 3 & 1 & 1 \\
\hline $844 B$ & 56.20 & 8.888 & i & 2 & 2 & $\mathrm{i}$ \\
\hline $844 \mathrm{C}$ & 58.95 & 9.226 & I & 1 & 3 & I \\
\hline $844 \mathrm{~B}$ & 59.30 & 9.280 & 4 & 4 & 0 & i \\
\hline $844 \mathrm{C}$ & 60.35 & 9.443 & 0 & 0 & 4 & 0 \\
\hline $844 \mathrm{~B}$ & 60.90 & 9.496 & i & 1 & 3 & 0 \\
\hline $844 \mathrm{~B}$ & 62.30 & 9.618 & 0 & 0 & 4 & 0 \\
\hline $844 \mathrm{C}$ & 62.95 & 9.684 & 4 & 3 & 2 & 1 \\
\hline $844 B$ & 63.80 & 9.752 & 0 & 0 & 4 & 0 \\
\hline $844 \mathrm{~B}$ & 65.30 & 9.874 & 0 & 0 & 4 & 0 \\
\hline $844 \mathrm{~B}$ & 66.80 & 9.995 & 4 & 3 & I & I \\
\hline $844 B$ & 69.25 & 10.212 & 4 & 4 & 1 & 0 \\
\hline $844 \mathrm{~B}$ & 70.75 & 10.346 & 4 & 4 & 0 & 0 \\
\hline $844 B$ & 73.76 & 10.596 & 4 & 4 & 0 & 0 \\
\hline $844 \mathrm{~B}$ & 75.27 & 10.693 & 4 & 4 & I & 0 \\
\hline $844 \mathrm{~B}$ & 76.77 & 10.762 & 4 & 3 & I & 1 \\
\hline $844 \mathrm{~B}$ & 78.61 & 10.847 & 3 & 2 & 2 & 1 \\
\hline $844 \mathrm{~B}$ & 80.25 & 10.922 & 4 & 4 & I & 0 \\
\hline $844 B$ & 81.45 & 10.978 & 4 & 4 & i & 0 \\
\hline $844 \mathrm{~B}$ & 83.25 & 11.039 & 4 & 4 & 1 & 0 \\
\hline $844 \mathrm{~B}$ & 86.25 & 11.136 & 4 & 4 & i & 0 \\
\hline $844 B$ & 89.75 & 11.248 & 4 & 4 & 1 & 0 \\
\hline $844 \mathrm{C}$ & 95.96 & 11.434 & 4 & 4 & 0 & 0 \\
\hline $844 B$ & 100.90 & 11.566 & 4 & 4 & 0 & 0 \\
\hline $844 \mathrm{C}$ & 105.93 & 11.700 & 4 & 3 & 0 & 1 \\
\hline $844 B$ & 113.49 & 11.901 & 4 & 4 & 0 & i \\
\hline $844 \mathrm{C}$ & 116.61 & 11.984 & 4 & 3 & 0 & 1 \\
\hline $844 \mathrm{~B}$ & 119.63 & 12.092 & 4 & 3 & 0 & i \\
\hline $844 \mathrm{~B}$ & 121.13 & 12.146 & 4 & 3 & 0 & I \\
\hline $844 \mathrm{~B}$ & 123.12 & 12.218 & 4 & 3 & 1 & I \\
\hline $844 B$ & 124.90 & 12.282 & 4 & 3 & i & i \\
\hline $844 \mathrm{~B}$ & 127.90 & 12.391 & 4 & 3 & 1 & 1 \\
\hline $844 \mathrm{~B}$ & 130.90 & 12.499 & 4 & 2 & I & 2 \\
\hline $844 \mathrm{~B}$ & 132.75 & 12.566 & 4 & 2 & 1 & 2 \\
\hline $844 \mathrm{~B}$ & 133.93 & 12.609 & 4 & 2 & I & 2 \\
\hline $844 \mathrm{C}$ & 1 36.62 & 12.679 & 4 & 3 & i & I \\
\hline $844 B$ & 136.93 & 12.685 & 4 & 2 & 1 & 2 \\
\hline $844 B$ & 143.09 & 12.820 & 4 & 4 & 1 & 1 \\
\hline $844 \mathrm{C}$ & 147.71 & 12.922 & 4 & 3 & i & 2 \\
\hline $844 B$ & 152.82 & 13.053 & 4 & 4 & 0 & I \\
\hline $844 \mathrm{C}$ & 157.70 & 13,180 & 4 & 4 & 0 & I \\
\hline $844 \mathrm{~B}$ & 163.61 & 13.340 & 4 & 3 & 0 & 2 \\
\hline $844 \mathrm{C}$ & 167.66 & 13.455 & 4 & 3 & 0 & 2 \\
\hline $844 B$ & 172.20 & 13.583 & 4 & 3 & 0 & 2 \\
\hline $844 \mathrm{C}$ & 178.50 & 13.761 & 4 & 3 & 0 & 2 \\
\hline $844 B$ & 178.70 & 13.767 & 4 & 3 & 0 & 2 \\
\hline $844 \mathrm{~B}$ & 181.70 & 13.851 & 4 & 3 & 0 & 2 \\
\hline $844 \mathrm{~B}$ & 183.48 & 13.901 & 4 & 4 & 0 & 1 \\
\hline $844 B$ & 185.35 & 13.954 & 4 & 2 & 0 & 2 \\
\hline
\end{tabular}

Only the first page of this table is reproduced here. The entire table appears on the CD-ROM (back pocket). 